\title{
THE EFFECT OF pH AND HYDRAULIC RETENTION TIME ON PRODUCTION OF VOLATILE FATTY ACIDS FROM PRIMARY SLUDGE ANAEROBIC FERMENTATION
}

\author{
By \\ Umme Sharmeen Hyder, \\ BSc Chemical Engineering, \\ Bangladesh University of Engineering and Technology, \\ Dhaka, Bangladesh, 2005
}

\author{
A thesis \\ presented to Ryerson University \\ in partial fulfillment of the \\ requirements for the degree of \\ Master of Applied Science \\ in the program of
}

Civil Engineering

Toronto, Ontario, Canada, 2018

CUmme Sharmeen Hyder, 2018 


\section{Author's declaration for electronic submission of a thesis}

I hereby declare that I am the sole author of this thesis. This is a true copy of the thesis, including any required final revisions, as accepted by my examiners.

I authorize Ryerson University to lend this thesis to other institutions or individuals for the purpose of scholarly research.

I further authorize Ryerson University to reproduce this thesis by photocopying or by other means, in total or in part, at the request of other institutions or individuals for the purpose of scholarly research.

I understand that my thesis may be made electronically available to the public. 
The effect of $\mathrm{pH}$ and hydraulic retention time on the production of volatile fatty acids from primary sludge anaerobic fermentation

Master of Applied Science, 2018

Umme Sharmeen Hyder, Civil Engineering, Ryerson University.

\begin{abstract}
Primary Sludge (PS) from wastewater treatment plants contains high biodegradable organic matter and therefore can be used to produce Volatile Fatty Acids (VFAs). The produced VFAs can be utilized in biological nitrogen and phosphorus removal processes as an external carbon source. The objective of this research was to investigate the effect of $\mathrm{pH}$ and hydraulic retention time (HRT) on the production of VFAs from PS through the anaerobic fermentation process. The experiments were conducted in both batch and semi-continuous flow regimes using bench scale fermenters under the mesophilic temperature. The Design of experiments included the HRT of $1-3$ days and $\mathrm{pH}$ range of $4.5-11.0$ for batch and $4.5-6.5$ for semi-continuous modes. According to the obtained results, the VFAs production increased with an increase in HRT from 1 to 3 days. For the batch study, the $\mathrm{pH}$ range for maximum VFAs yield was $\mathrm{pH} 6.5-10.0$ achieved at HRT of 3 days. For the semi-continuous study, the maximum amount of VFAs production was observed at a pH of 6.5 and HRT of 3 days.
\end{abstract}




\section{Acknowledgments}

Above all, I would thank Almighty ALLAH, for all his blessings.

Foremost, I would like to acknowledge my appreciation for TORAN UV Technologies and Southern Ontario Water Consortium (SOWC) for their funding to continue my research; and to Mr. Domenico Santoro, the research team leader from Trojan UV Technology for keeping continuous track of financial support for the project as well as true guidance on research work.

I would like to express my sincere gratitude to my supervisor Dr. Elsayed Elbeshbishy for his tremendous support for my MASc study and research. It was only his immense knowledge, patience and guidance that showed me the correct pathway for initiating the literature study thereby kick-starting of the project. It would not have been possible for me without his insight and motivation to successfully progress and complete this research activity and finalize this report.

My sincere thanks also go to Dr. Ahmad Eldyasti from York University giving the logistic support providing the fermenter and accessories. I also thanks Tommaso Gambassi who maintained an on-time requisition raise for lab consumables and supplies.

I would also thank my fellow lab mates Frances Okyoe, Anahita Rabii for being my mentor and guide when I was new to the lab. It was their all-time support and sympathy that let me learn all the analyses thereby leading me to become an active researcher in the lab. Thanks to Dr. Amir Bazayer, Dr. Ehssan Hossain, Dr. Amineh Azizi for helping me with troubleshooting the fermentation and brainstorming discussions. Thanks to Robin Luong for being a great help when required. 
Finally, to my family, my husband Mohammad Shafiqul Islam for being such a perfect life partner for providing me with unfailing support and continuous encouragement throughout my years of study and through the process of researching and writing this thesis. It was only possible for me to study late at night during exams and work in the lab during weekends as my husband was there to take care of my daughter Shamila Aynaz and son Mohammad Shahrad Latif Islam.

Last but not the least, my heartfelt love and gratitude to my parents Dr. Shameem Hyder and Mrs. Umme Melhan for supporting me spiritually and elevating my mental strength. Thanks to my dad for making me dream big and thanks to mom for always being there to help me into the path of the fulfillment of my dream.

This accomplishment would not have been possible without all of them. Thank you. 


\section{Table of Contents}

Author's declaration for electronic submission of a thesis.................................ii

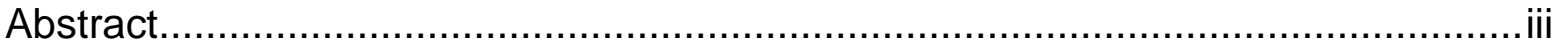

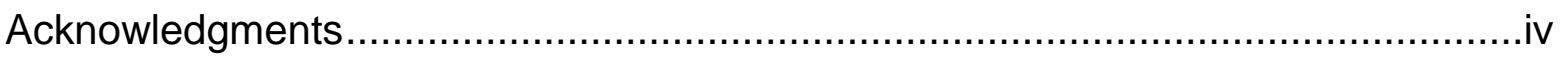

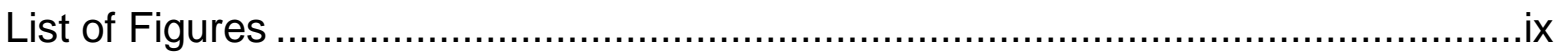

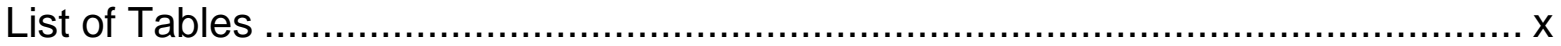

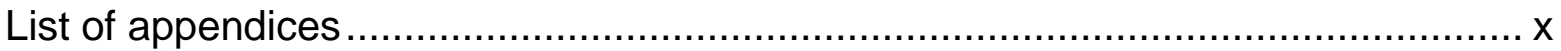

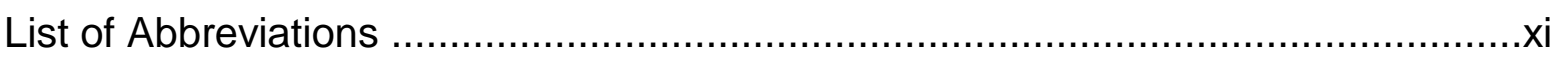

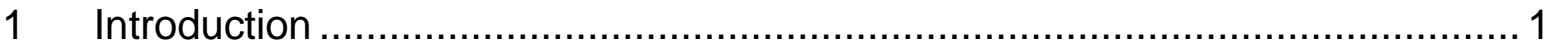

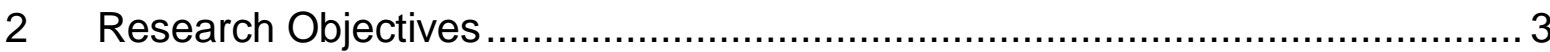

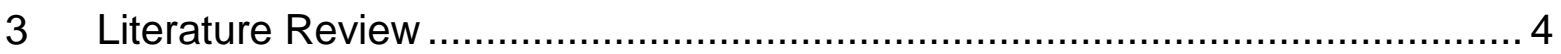

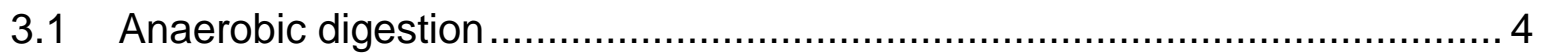

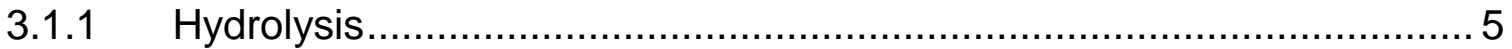

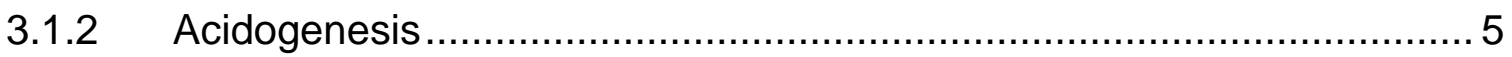

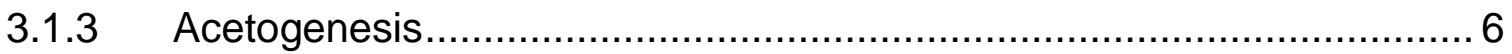

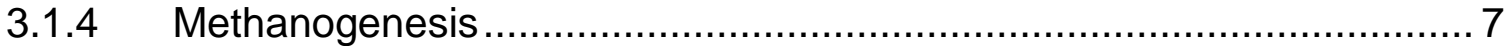

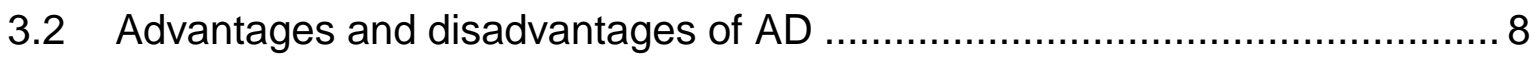

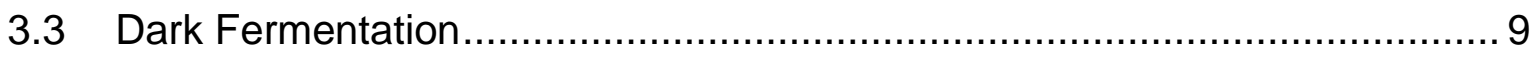

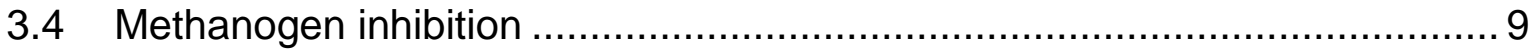

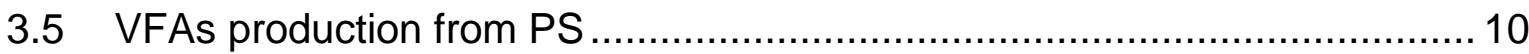

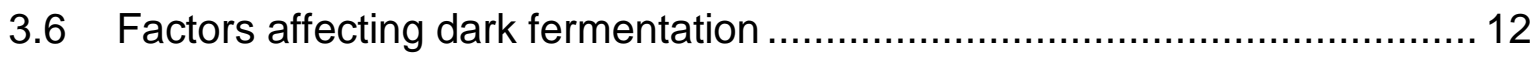

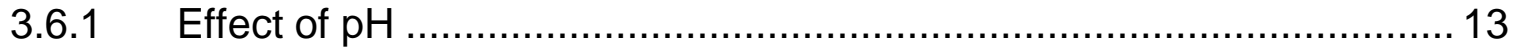

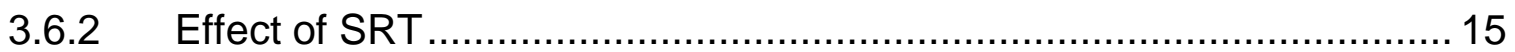

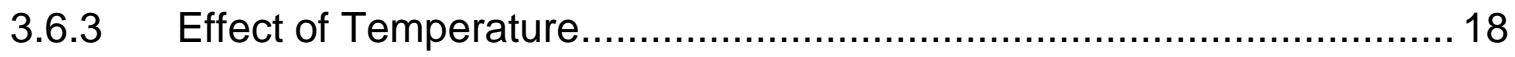

3.7 Alkaline fermentation of PS sludge............................................. 19

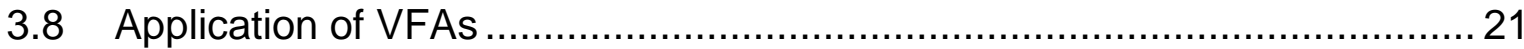

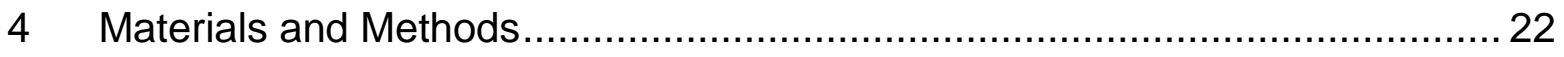

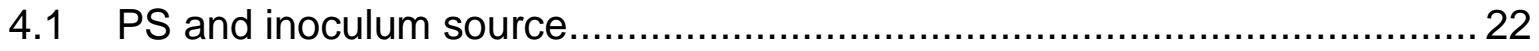

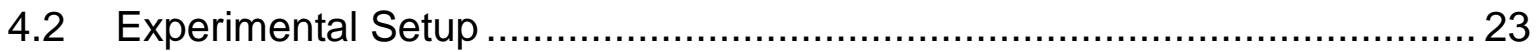

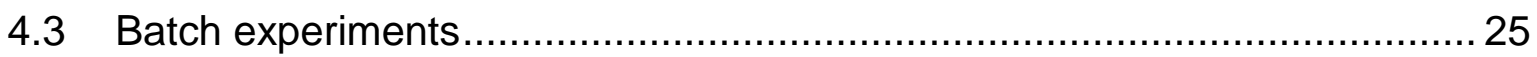




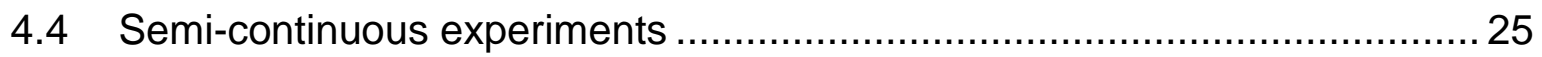

4.5 Feeding substrate and collecting effluent semi-continuous study............... 25

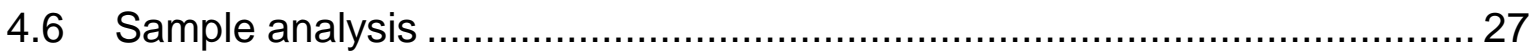

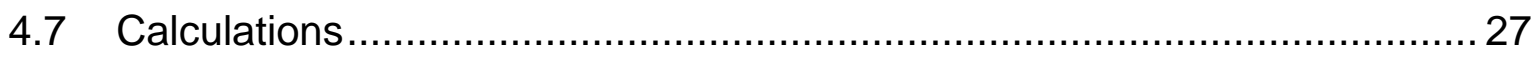

- The degree of solubilization batch experiment ......................................... 27

- Degree of solubilization semi-continuous experiment .................................28

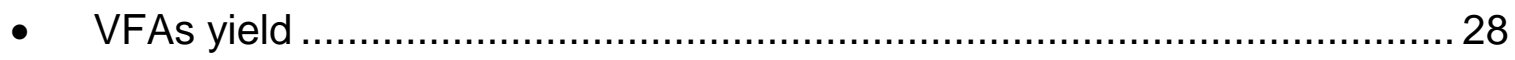

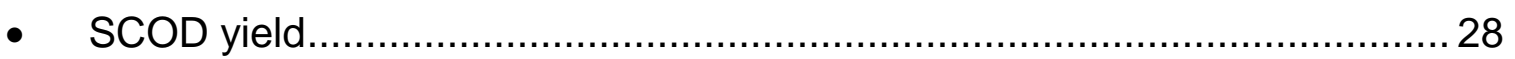

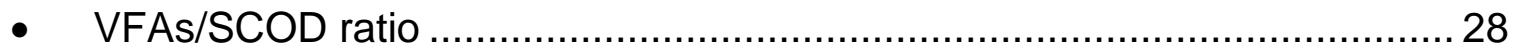

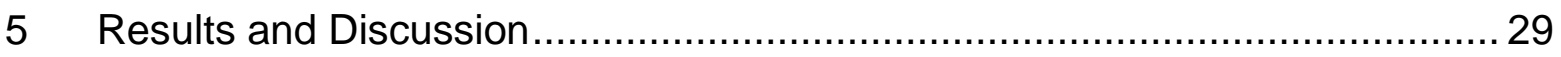

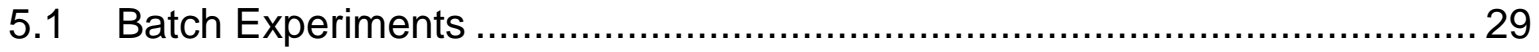

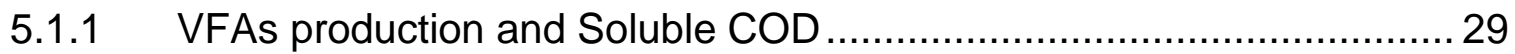

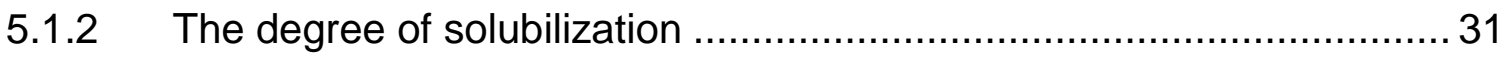

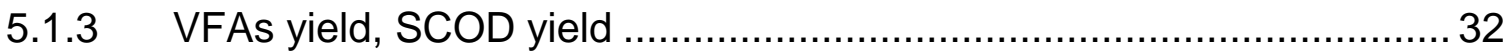

5.1.4 Discussion of batch experiment results ........................................... 36

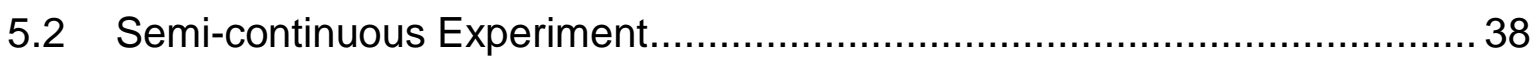

5.2.1 Characteristics of feed stock i.e., PS ............................................. 39

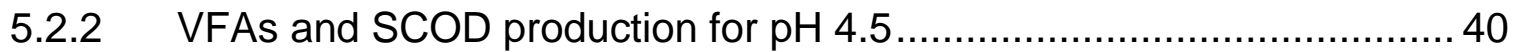

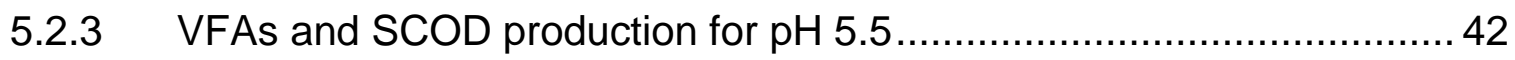

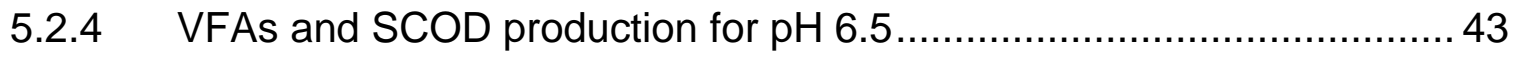

5.2.5 VFAs and SCOD production for $\mathrm{pH} 4.5,5.5,6.5$ and different HRTs ... 45

5.2.6 The degree of solubilization for $\mathrm{pH} 4.5,5.5,6.5$ and different HRTs ...... 46

5.2.7 VFAs yield, SCOD yield, VFAs/SCOD ratio ..................................... 48

5.2.8 Discussion on Semi-continuous experiment results .......................... 50

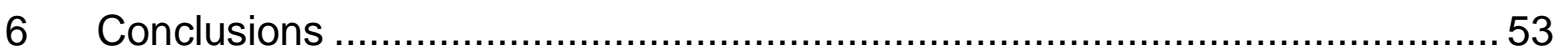

6.1 Anaerobic fermentation of PS batch study ............................................. 53

6.2 Anaerobic fermentation of PS semi-continuous study …..........................53

$7 \quad$ Recommendations and Future Research ...................................................... 55

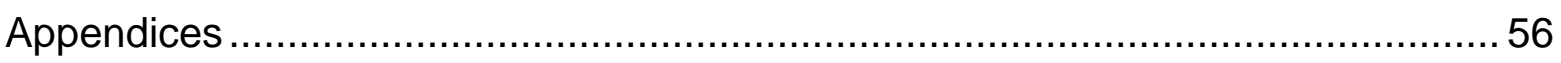

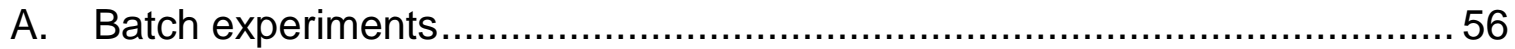


B. Semi-continuous experiments .....

C. One-way ANOVA, Fisher pairwise comparison for batch experiment .........63

D. One-way ANOVA, Fisher pairwise comparison for semi-continuous

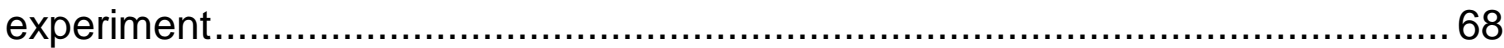

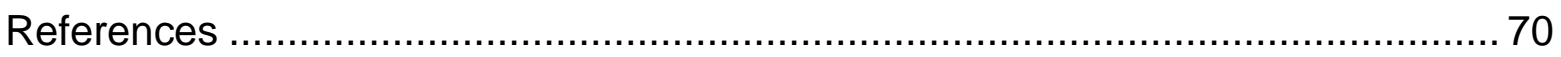




\section{List of Figures}

Figure 1 Pathways for anaerobic digestion (AD) process [9].................................... 4

Figure 2 Carbon and hydrogen flow in the anaerobic digestion process [9] .................. 7

Figure 3 Photograph for bench scale PS anaerobic acid fermentation experimental set

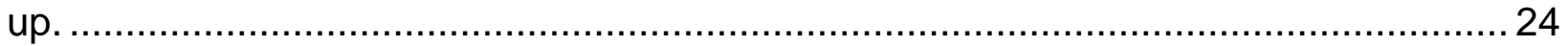

Figure 4 Schematic diagram for a bench scale experimental setup for PS anaerobic acid

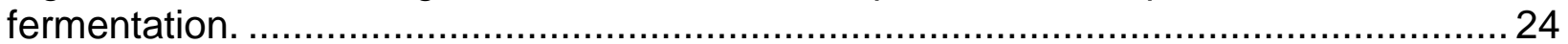

Figure 5 VFAs production during batch studies through PS anaerobic acid fermentation

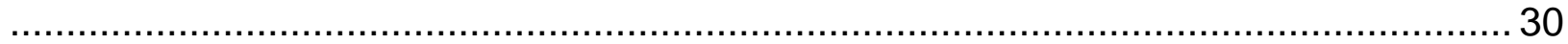

Figure 6 SCOD data for the batch experiment …….......................................... 30

Figure 7 Degree of solubilization for the batch experiment ..................................... 32

Figure 8 SCOD yield subject to VSS feed in batch studies of acid fermentation of PS .... 34

Figure 9 VFAs/SCOD as a percentage for acid fermentation of PS in batch studies .... 35

Figure 10 VFAs production data for $\mathrm{pH} 4.5$ and different HRTs ................................ 41

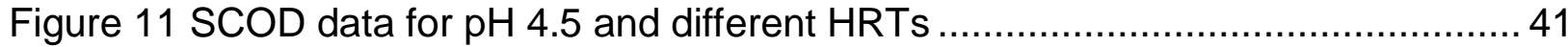

Figure 12 VFAs data for pH 5.5 and different HRTs ............................................ 42

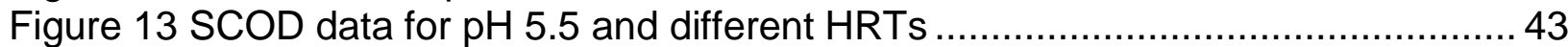

Figure 14 VFAs data for $\mathrm{pH} 6.5$ and different HRTs .............................................. 44

Figure 15 SCOD data for $\mathrm{pH} 6.5$ and different HRTs ........................................ 44

Figure 16 VFAs data for different HRTs and pHs for semi-continuous experiment ....... 45

Figure 17 SCOD data for different HRTs and pHs for semi-continuous experiment ..... 46

Figure 18 Degree of solubilization different HRTs and $\mathrm{pHs}$ for semi-continuous

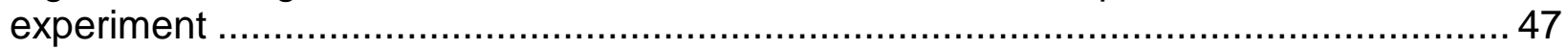

Figure 19 VFAs yield data for different HRTs and pHs for semi-continuous experiment

Figure $20 \mathrm{VFAs/SCOD}$ ratio for different HRTs and pHs for semi-continuous experiment

Figure 21 SCOD yield data for different HRTs and $\mathrm{pHs}$ for semi-continuous experiment 50 


\section{List of Tables}

Table 1 Advantages and disadvantages of the anaerobic process compared to the aerobic process [9]

Table 2 Temperature classification for the biological process with its optimum range [9]

Table 3 Characteristics of feed PS used in batch fermentation studies ....................... 23

Table 4 Data for batch study, VFAs, SCOD, VFAs and SCOD yields for PS fermentation 33

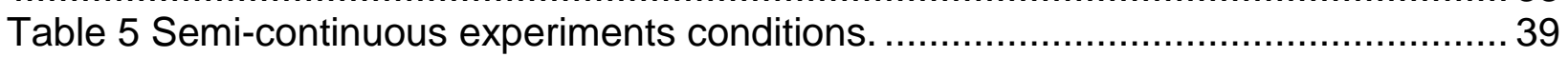

Table 6 Characteristics of feed PS for the semi-continuous reactor............................ 40

\section{List of appendices}

Table 7 Data for batch test of PS anaerobic fermentation $\mathrm{pH} 4.5$ at $35^{\circ} \mathrm{C}$...................56

Table 8 Data or batch test of PS anaerobic fermentation pH 5.5 at $35^{\circ} \mathrm{C}$....................56

Table 9 Data for batch test of PS anaerobic fermentation pH 6.5 at $35^{\circ} \mathrm{C}$...................56

Table 10 Data for batch test of PS anaerobic fermentation pH 8.0 at $35^{\circ} \mathrm{C}$................. 57

Table 11 Data for batch test of PS anaerobic fermentation pH 9.0 at $35^{\circ} \mathrm{C}$................. 57

Table 12 Data for batch test of PS anaerobic fermentation pH 10.0 at $35^{\circ} \mathrm{C} \ldots \ldots \ldots \ldots . . . . .57$

Table 13 Data for batch test of PS anaerobic fermentation $\mathrm{pH} 11.0$ at $35^{\circ} \mathrm{C}$...............57

Table 14 Data for semi-continuous PS anaerobic fermentation pH 4.5 HRT = 1 days

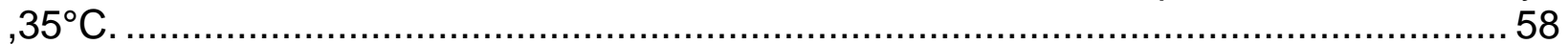

Table 15 Data for semi-continuous $P S$ anaerobic fermentation $\mathrm{pH} 4.5 \mathrm{HRT}=2$ days, $35^{\circ} \mathrm{C}$

Table 16 Data for semi-continuous anaerobic fermentation $\mathrm{pH} 4.5 \mathrm{HRT}=3$ days, $35^{\circ} \mathrm{C}$ 59

Table 17 Data for semi-continuous $P S$ anaerobic fermentation $p H 5.5 H R T=1$ days, $35^{\circ} \mathrm{C}$ 59

Table 18 Data for semi-continuous PS anaerobic fermentation $p H 5.5 H R T=2$ days

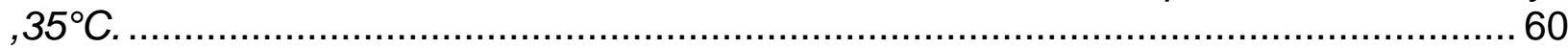

Table 19 Data for PS anaerobic fermentation semi-continuous study $\mathrm{pH} 5.5 \mathrm{HRT}=3$ days

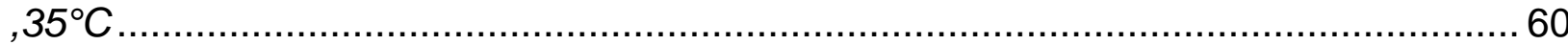

Table 20 Data for semi-continuous study of PS anaerobic fermentation pH $6.5 H R T=1$ days, $35^{\circ} \mathrm{C}$...... 61

Table 21 Data for semi-continuous study of PS anaerobic fermentation pH 6.5 HRT $=2$

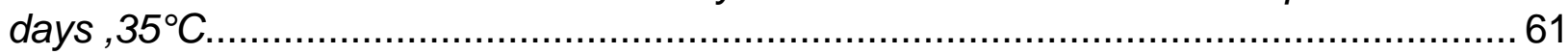

Table 22 Data for semi-continuous study of PS anaerobic fermentation pH 6.5 HRT = 3

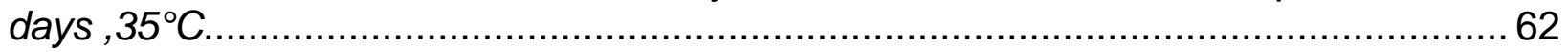
Table 23 VFAs yield, SCOD yield, VFAs/SCOD, degree of solubilization data for semicontinuous study of PS anaerobic fermentation $35^{\circ} \mathrm{C}$ 62 


\section{List of Abbreviations}

ABWWTP - Ashbridge's Bay wastewater treatment plant

$A D$ - Anaerobic Digestion

BNR - Biological Nutrient Removal

$\mathrm{BOD}_{5}-$ Biochemical Oxygen Demand

COD - Chemical Oxygen Demand

CSTR - Continuous Stirred tank reactor

HAc - Acetic Acid

$\mathrm{HBu}$ - Butyric Acid

$\mathrm{HPr}$ - Propionic Acid

MWWTP - Municipal Waste Water Treatment Plant

PS - Primary Sludge

PVC - Poly Vinyl Chloride

SCFA- Short Chain Fatty Acids

SCOD - Soluble Chemical Oxygen Demand

TCOD - Total Chemical Oxygen Demand

TS- Total Solid

TSS - Total Suspended Solids

VFAs - Volatile Fatty Acids

VSS - Volatile Suspended Solids

WAS - Waste Activated Sludge

TWAS - Thickened Waste Activated Sludge

WWTP - Wastewater Treatment Plant 


\section{Introduction}

Waste generation and management have been a concern in the modern world. Compared to other waste management methods (i.e., landfilling, incineration, and composting), the resource recovery from organic waste provides the provision for waste minimization as well as the production of the value-added products. In this regard, the primary sludge (PS) from municipal wastewater treatment plants (MWWTP) can be considered as a rich source for the production of volatile fatty acids (VFAs) as a value-added product and therefore, it has drawn an extensive research interest through the acidogenesis process [1]. Acidogenesis is also termed as dark fermentation [2]. VFAs are short-chain fatty acids with six or fewer carbon atoms which can be used in bioplastic and bioenergy production as well as in biological nutrient removal (BNR) process as a carbon source [3].

Anaerobic Digestion (AD) has an acidification step in which VFAs such as acetic acid $(\mathrm{HAc})$, propionic acid $(\mathrm{HPr})$, and butyric acid $(\mathrm{HBu})$ are produced as the intermediate metabolic products. VFAs production from organic wastes such as PS occurs through the dark fermentation process consists of two sequential steps, hydrolysis and acidogenesis. During the first step (hydrolysis), the high molecular weight organic compounds like complex organic polymers are broken down into simple and soluble organic monomers by the enzymes produced by the hydrolytic microorganisms. The hydrolysis step is characterized by an increase in soluble chemical oxygen demand (SCOD). The next step in the dark fermentation is the acidogenesis process during which the generated SCOD from the hydrolysis step is converted to VFAs (HAc, HPr, HBu) in the presence of the acidogenic microorganisms. Both the hydrolysis and acidogenesis processes occur in the 
anaerobic condition via anaerobic microorganisms such as Bacteriocides, Clostridia, Bifidobacteria, Streptococci, and Enterobacteriaceae [4]. The performance of the fermentation process depends on different environmental and operational factors such as $\mathrm{pH}$, temperature, solid retention time (SRT), organic loading rate (OLR), etc. Among various organic waste sludges, previous studies have mainly focused on the production of VFAs from PS, since it is one of the largely produced organic waste in MWWTPs. The total chemical oxygen demand (TCOD) of PS ranges between $15,000 \mathrm{mg} \mathrm{l}^{-1}$ and 60,000 $\mathrm{mg} \mathrm{l}^{-1}$ which suggests its high potential for VFAs production [5]. One application of the produced VFAs form PS is to utilize it as a carbon source for the BNR process. On average, the removal of $1 \mathrm{mg}$ of phosphorus $(\mathrm{P})$ through the BNR process requires 7 to $9 \mathrm{mg}$ of VFAs [6]. It was reported that the required level of the $\mathrm{P}$ concentration to treated wastewater would be $0.2-0.3 \mathrm{mg} \mathrm{l}^{-1}[7]$. Considering these explanations, this research will investigate the effect of $\mathrm{pH}$ and SRT on the performance of the dark fermentation process to produce VFAs from PS. 


\section{Research Objectives}

The primary objective of this study was to evaluate the effect of $\mathrm{pH}$ and HRT on the fermentation of the PS to maximize the SCOD and VFAs production. The goal of the project was to maximize the produced VFAs that can be used as a carbon source for the BNR process.

For this purpose, experiments were conducted under both batch and semi-continuous flow regimes. The experiments were first conducted under batch mode at different $\mathrm{pH}$ levels from 4.5-11.0. During the batch experiment, samples were collected at 1, 2 , and 3 days intervals. After the batch test, semi-continuous fermenters were operated at three $\mathrm{pH}$ levels $(4.5,5.5$, and 6.5$)$ and under three HRTs of 1,2 , and 3 days. The HRT was kept low until 3 days to ensure VFAs production and inhibit the further step in AD which is methanogenesis that will consume VFAs [8]. The performance of the fermenters was evaluated by monitoring the SCOD and VFAs concentration and yield throughout the process. 


\section{Literature Review}

\subsection{Anaerobic digestion}

Anaerobic digestion (AD) is a multi-step process during which organic matter is converted into methane-rich biogas in the absence of oxygen and in the presence of anaerobic microorganisms [9]. The AD process occurs through four major sequential steps including hydrolysis, acidogenesis, acetogenesis, and methanogenesis. Throughout the overall digestion process, the hydrolysis has been known as the rate limiting step [10]. The fermentation process is an $A D$ process that progresses until the end of the acetogenesis stage. The main biochemical pathways involved in AD is shown in Figure 1. The produced biogas typically consists of $60-70 \%$ methane $\left(\mathrm{CH}_{4}\right)$ and $20-30 \%$ carbon dioxide $\left(\mathrm{CO}_{2}\right)$ and fractions of other gases $\left(\mathrm{H}_{2}\right.$ and $\left.\mathrm{H}_{2} \mathrm{~S}\right)[9]$.

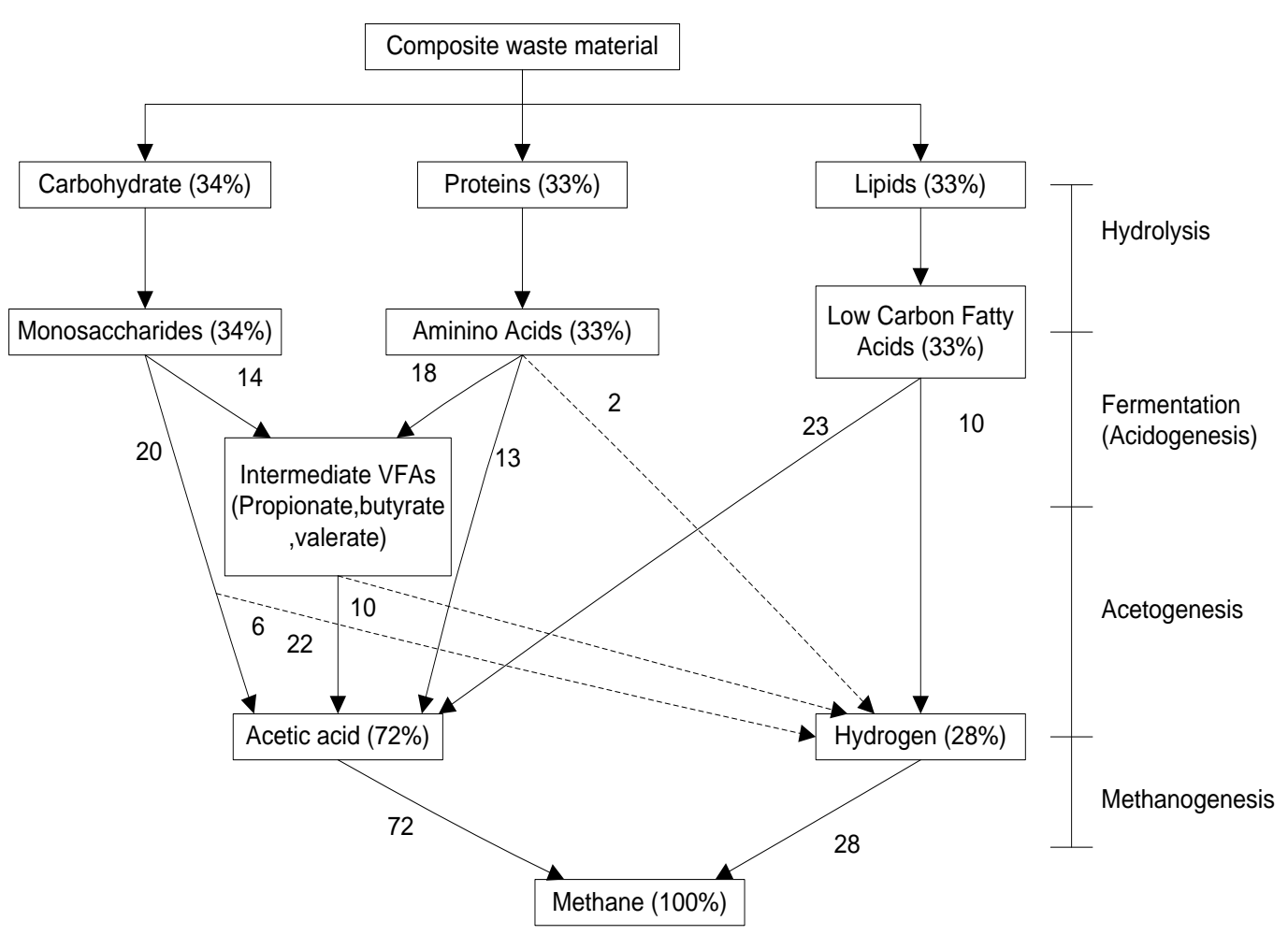

Figure 1 Pathways for anaerobic digestion (AD) process [9]. 


\subsubsection{Hydrolysis}

Hydrolysis is the first step of the digestion or fermentation process. During hydrolysis, particulate organic matter is converted to soluble compounds that can be further degraded to the simple monomers. These monomers are later used by the acidogenic bacteria to produce VFAs. For example, polymeric substrates such as cellulose, protein, and lipid (fat and oil) are converted to soluble molecules of sugar (glucose and xylem), amino acid, and long chain fatty acids (13 to 21 carbons), respectively. During the hydrolysis process, proteins are converted to amino acids by proteases secreted by proteolytic microbes. The cellulase and xylanase enzymes produced by cellulitis and xylanolytic microbes convert the complex sugar molecules into glucose and xylem, respectively. Lastly, lipases which are created by lipolytic microbes convert lipids to longchain fatty acids and glycerol [11]. The general reactions occurring through the hydrolysis stage are shown below [12].

\section{Hydrolysis/Liquefaction reactions}

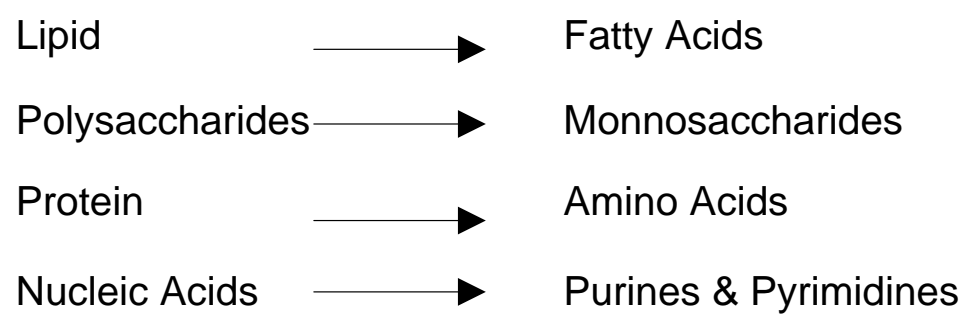

\subsubsection{Acidogenesis}

Acidogenesis is the stage through which anaerobic bacteria convert sugars, amino acids, and long-chain VFAs to acetate, hydrogen, carbon dioxide, and short chain VFAs (i.e., $\mathrm{HPr}, \mathrm{HBu}$, and $\mathrm{HAc}$ ), ketones, alcohols, and lactic acid. Conversion of glucose to acetate, ethanol, and propionate are shown in the reactions 1,2 and 3 below respectively [12]. 


$$
\begin{aligned}
& \mathrm{C}_{6} \mathrm{H}_{12} \mathrm{O}_{6}+2 \mathrm{H}_{2} \mathrm{O} \rightarrow 2 \mathrm{CH}_{3} \mathrm{COOH}+2 \mathrm{CO}_{2}+4 \mathrm{H}_{2} \\
& \mathrm{C}_{6} \mathrm{H}_{12} \mathrm{O}_{6} \rightarrow 2 \mathrm{CH}_{3} \mathrm{CH}_{2} \mathrm{OH}+2 \mathrm{CO}_{2} \\
& \mathrm{C}_{6} \mathrm{H}_{12} \mathrm{O}_{6}+2 \mathrm{H}_{2} \rightarrow 2 \mathrm{CH}_{3} \mathrm{CH}_{2} \mathrm{COOH}+2 \mathrm{H}_{2} \mathrm{O}
\end{aligned}
$$

In an equilibrium condition, most of the organic matter are converted into substrates such as acetate, hydrogen, and carbon dioxide that will be used by the methanogenic microbes. As the byproduct of the amino acids fermentation, ammonia, and hydrogen sulfide are released [11]. The high concentration of these compounds can cause inhibition for AD process [12].

\subsubsection{Acetogenesis}

During acetogenesis, VFAs with more than two atoms of carbon, alcohols, and aromatic fatty acids are converted into acetate via obligate hydrogen-producing bacteria [12]. In this step, the products of the first phase are converted to simple organic acids, carbon dioxide and hydrogen by acetogenic bacteria, also called acid formers. The activities of different microorganisms cause the formation of different products during the acetogenesis process. These microorganisms include syntrophobacter wolinii, a propionate decomposer, and sytrophomonos wolfei, a butyrate decomposer. Also, other acid formers include clostridium spp., peptococcus anerobus, lactobacillus, and Actinomyces. Each group of microorganisms follows different pathways. For example, the hydrogen-producing acetogenic bacteria yield acetate, $\mathrm{H}_{2}$ and, $\mathrm{CO}_{2}$ from VFAs and alcohol, whereas, homoacetogenic bacteria produce acetate from $\mathrm{CO}_{2}$ and $\mathrm{H}_{2}$. However, most of the acetate is formed via hydrogen producing acetogenic bacteria [12]. 


\subsubsection{Methanogenesis}

The fourth step, methanogenesis, is carried out by a group of organisms called methanogens. Two groups of methanogens are generally involved in methane production. One group is acetoclastic methanogens that convert acetate into methane and $\mathrm{CO}_{2}$. The second one is hydrogen-utilizing methanogens that use hydrogen as an electron donor and $\mathrm{CO}_{2}$ as an electron acceptor to produce methane. According to Figure 2 , about $70 \%$ of the methane produced during the methanogenesis stage is from acetate. Based on the type of the substrate consumed by the methanogens, the methanogenesis process can be classified into two main categories [12]:

1) Hydrogenotrophic methanogenesis during which hydrogen and carbon dioxide are converted into methane through the following reaction:

$$
\mathrm{CO}_{2}+4 \mathrm{H}_{2} \rightarrow \mathrm{CH}_{4}+2 \mathrm{H}_{2} \mathrm{O}
$$

2) Acetoclastic methanogenesis which involves the formation of methane from the conversion of acetate by through the following reaction:

$$
\mathrm{CH}_{3} \mathrm{COOH} \rightarrow \mathrm{CH}_{4}+2 \mathrm{CO}_{2}
$$

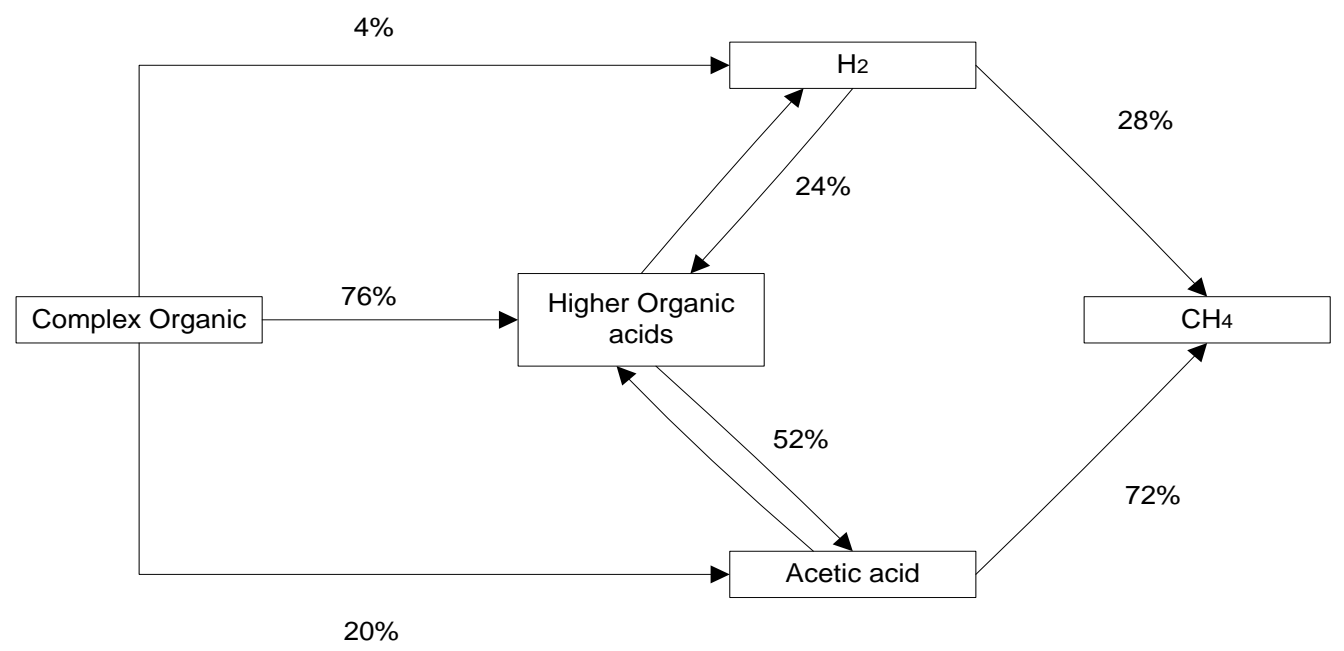

Figure 2 Carbon and hydrogen flow in the anaerobic digestion process [9] 


\subsection{Advantages and disadvantages of $A D$}

$A D$ is primarily applied for the treatment of both organic solid waste and high strength (concentrated) wastewater. In addition to the energy recovery in the form of methane, the AD has other advantages, which includes waste volume reduction, reduced odor potential, and reduced pathogen content of the of the digested compounds (digestate). Most of the previous lab and full-scale application of $A D$ were carried on under the mesophilic temperature range $\left(30-40^{\circ} \mathrm{C}\right)$, but several studies and field applications have been also conducted under the thermophilic condition $\left(45-65^{\circ} \mathrm{C}\right)[9]$.

The advantages and disadvantages of the AD process is listed in Table 1

Table 1 Advantages and disadvantages of the anaerobic process compared to the aerobic process [9]

\begin{tabular}{|l|l|}
\hline Advantages & Disadvantages \\
\hline Less energy required & $\begin{array}{l}\text { Longer startup time to develop necessary } \\
\text { biomass recovery }\end{array}$ \\
\hline Less biological sludge production & Might require alkali addition \\
\hline Less nutrient required & $\begin{array}{l}\text { May require further treatment with anaerobic } \\
\text { treatment process to meet discharge } \\
\text { requirement }\end{array}$ \\
\hline $\begin{array}{l}\text { Methane production is a potential energy } \\
\text { source }\end{array}$ & $\begin{array}{l}\text { Biological phosphorus and nitrogen removal is } \\
\text { not possible }\end{array}$ \\
\hline Smaller reactor volume required & $\begin{array}{l}\text { More sensitive to the negative effect of lower } \\
\text { temperatures on reaction rates }\end{array}$ \\
\hline Elimination of off-gas air pollution & $\begin{array}{l}\text { More susceptible to upsets due to toxic } \\
\text { substances or broad feeding changes }\end{array}$ \\
\hline $\begin{array}{l}\text { Able to respond quickly to substrate addition } \\
\text { after long periods without feeding }\end{array}$ & $\begin{array}{l}\text { The potential for odor production and } \\
\text { corrosiveness of gas }\end{array}$ \\
\hline Effective pre-treatment process & \\
\hline The potential for lower carbon footprint & \\
\hline
\end{tabular}




\subsection{Dark Fermentation}

During the fermentation process, the hydrolytic microorganisms hydrolyze complex organic polymers to monomers that are further converted to a mixture of low molecular weight organic acids and alcohols by acidogenic bacteria. Previously, the PS has been widely used as a potential substrate for the dark fermentation process to produce VFAs. The efficiency of the dark fermentation process depends on different factors including the pretreatment process (if applicable), operating $\mathrm{pH}$, temperature, SRT, and OLR along with the characteristics of the sludge [13]. During the fermentation of PS, the carbohydrates are oxidized by electron acceptors, and eventually are converted to VFAs in the form of $\mathrm{CH}_{3} \mathrm{COOH}, \mathrm{CH}_{3} \mathrm{CH}_{2} \mathrm{COOH}$, etc. along with some hydrogen as intermediate products [14]. This process of partial conversion of PS to produce VFAs and hydrogen is indeed called dark fermentation. The overall reactions can be expressed as follows:

$$
\begin{aligned}
& \mathrm{C}_{6} \mathrm{H}_{12} \mathrm{O}_{6}+2 \mathrm{H}_{2} \mathrm{O} \rightarrow 2 \mathrm{CH}_{3} \mathrm{COOH}+4 \mathrm{H}_{2} \ldots \ldots \\
& \mathrm{C}_{6} \mathrm{H}_{12} \mathrm{O}_{6}+2 \mathrm{H}_{2} \mathrm{O} \rightarrow 2 \mathrm{CH}_{3} \mathrm{CH}_{2} \mathrm{COOH}+2 \mathrm{H}_{2}
\end{aligned}
$$

\subsection{Methanogen inhibition}

Compared to the other microorganisms involved in the AD process, the methanogenic bacteria are susceptible to the change in the environmental conditions. The optimal $\mathrm{pH}$ of methanogen is 7.0-8.5 [15]. Below pH 6.6, significant inhibition of methanogenic bacteria occurs. When $\mathrm{pH}$ drops below 6.2, acid conditions become inhibitory to the methanogenic bacteria as acid production continues. The fermentative bacteria continue to produce VFAs until pH drops to 4.5 or 5.0 [16]. Methanogenic bacteria become active 
at $\mathrm{pH}$ above 6.0 [15] and therefore one way to limit their activity during the fermentation process is to keep the $\mathrm{pH}$ level below 6.0 throughout the process [17].

\subsection{VFAs production from PS}

Several studies have been conducted to evaluate the feasibility of hydrolysis and acidification process for VFAs production from PS, WAS or mixed sludge (PS + TWAS). The readily biodegradable organic content of PS is much higher than that of the WAS and therefore, the VFAs yield and SCOD yield are generally higher for the PS [9]. Since PS is abundant in most of the MWWTPs, the production of VFAs from PS gives the provision to use it as a carbon source for the on-site BNR process, reducing the cost of external carbon source as well as the transportation cost. Considering these explanations, PS was selected as the substrate for VFAs production in the current study. The main outcomes of some of the previous studies conducted for the fermentation of PS are summarized below.

The mesophilic fermentation of PS, TWAS, and mixed sludge under the mesophilic temperature of $37^{\circ} \mathrm{C}$ and a SRT of 5 days was studied and resulted in the specific VFAs production rate of $270 \mathrm{mg} \mathrm{COD} \mathrm{g}^{-1} \mathrm{VSS}, 62 \mathrm{mg} \mathrm{COD} \mathrm{g}^{-1} \mathrm{VSS}$, and $114 \mathrm{mg} \mathrm{COD} \mathrm{g}^{-1} \mathrm{VSS}$, respectively [18]. And also the effect of PS samples from different origins was studied in another experiement with PS VSS content ranging from 15,290 to $29,100 \mathrm{mg} \mathrm{l}^{-1}$ [18]. The results showed consistent VFAs production potential and composition regardless of the initial VSS concentration [18]. It is known from the literature that the VFAs production from PS can be maximized by adjusting the $\mathrm{pH}$ and HRT conditions [19]. In terms of SRT,

under long SRTs, the production of methane will begin which will reduce the VFAs yield. It was reported at a temperature of $25^{\circ} \mathrm{C}$, the digestion of sludge at a SRT of 8 days 
resulted in methanogenic activity [20]. On the other hand, higher SRT leads to higher reactor volume associated with higher capital cost. Therefore, the SRT is kept as low as possible to avoid methanogenesis process and to minimize the cost. According to the literature, the optimum SRT of PS is suggested in a range of 3-5 days [21]. In another study and under semi-continuous flow regime, the SRT of 5 days was investigated to prevent the growth of methanogen and thereby to avoid the consumption of readily degradable CODs including VFAs [18]. PS generally contains a higher percentage of organic matter. The higher organic matter content of PS results in more bacterial activity and subsequently higher concentration of enzyme produced by hydrolytic bacteria [22]. In PS, organic matters are more biodegradable while for WAS organic matters are in polymer form which is difficult to degrade. The rigid cell structure of WAS made up of glycan and peptide make it intractable for microbial degradation [22].WAS cells are held together with extracellular polymeric substances (EPS) which also makes WAS challenging to biodegrade. An external mechanism such as pre-treatment is required to disintegrate WAS which is not necessary in the case of PS.

Volatile suspended solids (VSS) in PS were more biodegradable (87\%) than that of WAS (43\%) [23]. The ratio of SCOD to TCOD in a batch reactor operated at $20^{\circ} \mathrm{C}$ for five days for TWAS was significantly lower than that of PS [18]. The concentration of VSS in PS is a good indication of the biodegradable substrate. It was stated that the rate of the reaction was directly proportional to the initial biodegradable substrate concentration measured as VSS [24]. The effect of SRT on hydrolysis, acidification, and methanogenesis of PS in UASB and CSTR reactors at $25^{\circ} \mathrm{C}$ was studied by [20]. This study revealed that SRT $\leq 8$ days resulted in acidogenic conditions and SRT $\geq 8$ days shows methanogenic conditions 
[20]. The authors reported that the most substantial increase in hydrolysis and acidification of TCOD of PS occurs between SRT 1-3 days [20].

\subsection{Factors affecting dark fermentation}

Environmental conditions such as temperature and $\mathrm{pH}$ have an essential role in the selection, growth, and survival of microorganisms. Generally, the optimal growth of microorganism happens in a narrow range of temperature and $\mathrm{pH}$, but they can survive in broader limits. The previous studies confirmed that the effects of temperature in anaerobic fermentation are significant [9]. In general, the growth rate doubles for every $10^{\circ} \mathrm{C}$ increase in temperature until it reaches to the optimum temperature [9]. The typical and optimum temperature range for microorganisms are shown in Table 2 for psychrophilic, mesophilic, and thermophilic conditions [9].

Table 2 Temperature classification for the biological process with its optimum range [9]

\begin{tabular}{|l|l|l|}
\hline Type & Temperature range $\left({ }^{\circ} \mathrm{C}\right)$ & Optimum range $\left({ }^{\circ} \mathrm{C}\right)$ \\
\hline Psychrophilic & $10-30$ & $12-18$ \\
\hline Mesophilic & $20-50$ & $25-40$ \\
\hline Thermophilic & $35-75$ & $55-65$ \\
\hline
\end{tabular}

The $\mathrm{pH}$ of the environment is also a key factor for the metabolism and growth of microorganisms. Most bacteria cannot tolerate a pH level below 4.0 and above 9.5. The optimum $\mathrm{pH}$ for anaerobic bacterial growth lies between 6.5 and 7.5 [9]. Along with the progression of acid fermentation, VFAs are produced and the accumulation causes a drop in $\mathrm{pH}$ and thereby inhibiting the methanogenic activity. If the $\mathrm{pH}$ can be controlled below 
7.0, suitable $\mathrm{pH}$ environment can be kept for VFA production. Biochemical reactions of the AD process are catalyzed by enzymes. These organisms' dominant for each step of the $A D$ process has an optimum $\mathrm{pH}$ when the rate of reaction is maximum. For methanogens, $\mathrm{pH} 7.0-8.0$ is optimal; for fermentation $\mathrm{pH} 6.5$ - 8.5 is operational, $\mathrm{pH}$ 5.07.0 is optimal; and for hydrolysis $\mathrm{pH}$ 5.0-7.0 is optimal [15]. Deviation from optimum $\mathrm{pH}$ value during a fermentation process can be caused by the influent $\mathrm{pH}$, and the accumulation of acidic products such as VFAs or basic products such as ammonia [15].

Several studies have been conducted to evaluate the effect of the environmental and operational parameters including $\mathrm{pH}$, temperature, and SRT. The current section will summarize some observations from those studies. The yield and composition of VFAs are dependent on operational temperature, $\mathrm{pH}, \mathrm{HRT}$ and OLR [20].

\subsubsection{Effect of $\mathrm{pH}$}

Comparatively, few studies have been conducted to investigate the effect of $\mathrm{pH}$ on VFAs production from municipal waste sludge including PS and WAS especially under $\mathrm{pH}$ value below 5.0 [25]. Previous studies that have been conducted to identify the effect of $\mathrm{pH}$ on VFAs and biohydrogen production revealed that the optimum $\mathrm{pH}$ range to achieve maximum VFAs and hydrogen yield is in the range of 5 to 6 using either pure or mixed culture bacteria [26]. Previous research also showed that the level of $\mathrm{pH}$ affects the type, composition, and concentration of VFAs produced during the fermentation process [1]. The influence of $\mathrm{pH}$ on the acidification of PS in the complete mix fermenter was investigated and determined to be optimum at 6.8 at a temperature of $50^{\circ} \mathrm{C}$ [17]. No significant increase in VFAs production from PS fermentation at a controlled $\mathrm{pH}$ of 7.0

was observed compared to the uncontrolled $\mathrm{pH}$ at a range of 5.9-6.4 [17]. The acidic $\mathrm{pH}$ 
range in bioreactor inhibited methanogenesis with no methane gas production in reactor [27].

The influence of $\mathrm{pH}$ on acid phase anaerobic digestion of PS was examined in another study [25]. In this study, controlled and uncontrolled $\mathrm{pH}$ experiments were conducted using bench scale completely mixed reactor (CMR) with clarifier and solids recycle unit as well as a UASB reactor [25]. Specific VFA production rate, COD solubilization, and VSS reduction percentage for both CMR and UASB reactor were not affected by $\mathrm{pH}$ variation in a range of 4.3-5.2. However, at higher $\mathrm{pH}$ values (5.9-6.2), 25 - 30\% reduction was observed for the parameters [25]. Analysis of degradation behavior of carbohydrates, proteins, and lipids revealed that each organic class followed an individual trend concerning $\mathrm{pH}$ changes. Regardless of the level of $\mathrm{pH}$, HAc was the dominant VFAs product with an average of $45 \%$ in both reactors [25]. However, the composition of the produced VFAs was different in terms of $\mathrm{HPr}$ and $\mathrm{HBr}$ depending on the $\mathrm{pH}$ level [25].

The effect of $\mathrm{pH}$ on the production of VFAs from glucose was investigated in a CSTR for the $\mathrm{pH}$ range of 4.0-7.0. The authors reported the optimum $\mathrm{pH}$ for maximum VFA production to be 5.5 [28]. The study showed that butyrate and acetate were the two abundant VFAs in the effluent. Within the $\mathrm{pH}$ level between 4.0 and 6.0, the effluent contained $41.4-32.4 \%$ butyrate and $15.3-29.5 \%$ acetate. However, the pH levels of 6.5 to 7.0 resulted in an increase in acetate $(33.1-34.1 \%)$ and a decrease in butyrate (31.5$31.2 \%)$ concentration [28].

Another study was conducted to evaluate the effect of $\mathrm{pH}$ and temperature to produce soluble organics through the fermentation of PS [29]. In this study, parallel experiments were conducted under different $\mathrm{pH}$ and temperature conditions. It was reported that at a 
temperature of $20^{\circ} \mathrm{C}$, the uncontrolled $\mathrm{pH}$ resulted in SCOD and VFAs concentration of

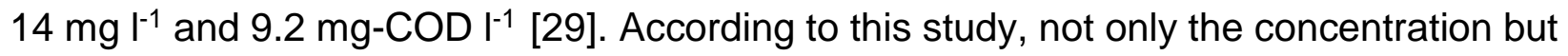
the composition of the VFAs also changed at higher $\mathrm{pH}$ levels. According to this research, at the low range of $\mathrm{pH}$, about $45 \%$ of the total produced VFAs was HAc. However, the HAc content of total VFAs reduced at higher $\mathrm{pH}$ levels [29]. Similar results were reported [30]. It is noteworthy that out of different VFAs, HAc is the preferred carbon source to be used in the BNR process [31]. PS from primary sediment was also investigated for producing carbon source through the fermentation process [32]. The system condition was as follows: temperature: $35^{\circ} \mathrm{C}$, SRT: 3 days, HRT: 28 hours. This system resulted in the SCOD and VFAs concentration of $975.5 \mathrm{mg} \mathrm{l}^{-1}$ and $516.4 \mathrm{mg} \mathrm{l}^{-1}$ [32].

\subsubsection{Effect of SRT}

In acidogenic fermentation of PS to produce VFAs, retention time is a critical parameter. Among the operational parameters of anaerobic digestion or dark fermentation, HRT (or SRT) is one of the most influential parameters on the growth of acidogens. HRT affects the net VFA production as it directly links to the contact time between substrate and microorganisms [31].

HRT is the amount of the theoretical time that water or liquid takes to travel through the entire system. HRT is calculated by the following equation (8).

$$
H R T=\frac{\text { Volume of the reactor }, V}{\text { Influent flow rate, } Q}=\frac{L}{\frac{L}{d}}=d
$$

SRT is the average time the cell mass stays in the reactor (9). For a CSTR, SRT can be calculated as follows: 


$$
S R T=\frac{\text { Mass of the reactor }}{\text { Mass rate of the solids leaving }}=\frac{V * T S S}{Q_{\text {out }} * T S S}=\frac{V}{Q_{\text {out }}}=H R T(d)
$$

For a CSTR semi-continuous system, HRT is equal to SRT. However, for a reactor with different HRT and SRT (with an sludge recycle line), under longer SRTs, microorganisms get more time to react with waste, but at longer HRTs, VFAs production becomes stagnant [33]. This can result in high organic loading rate [34].

Effect of HRT on PS acid-phase anaerobic fermentation was investigated using bench scale continuous flow reactors [25]. Results indicated that both VFAs and SCOD increased with increase in HRT up to $12 \mathrm{hrs,} \mathrm{but} \mathrm{drop} \mathrm{down} \mathrm{moderately} \mathrm{at} \mathrm{longer} \mathrm{HRTs}$ [25]. HAc (46\%) and HPr (32\%) were the main components of the VFAs formed [25]. Variation of HRT significantly impacts the organic substrate degradation [25]. Two completely mixed reactors (CMR) with $3 \mathrm{~L}$ volume and solid recycling ability were used to investigate the effect of HRT and temperature on VFAs production [7]. One reactor was filled with PS only, while the other one was fed with PS and industrial wastewater full of starch. VFAs and SCOD concentration reached maximum values at HRT $30 \mathrm{hrs}$ at $25^{\circ} \mathrm{C}$ [7].

Two bench-scale CMRs were used to investigate the acidogenesis of PS at different HRT and temperature [27]. Increasing the HRT from 18 to 30 hours improved the substrate solubilization in both the reactors [27]. At the HRT of $18 \mathrm{hrs}$., temperature of $22^{\circ} \mathrm{C}$, and $\mathrm{pH}$ of 5.63-5.77, the net VFAs production was $273 \pm 61 \mathrm{mg} \mathrm{l}^{-1}$ [27]. VFAs production was increased by $14 \%\left(329 \pm 52 \mathrm{mg} \mathrm{l}^{-1}\right)$ with an increase in HRT to 30 hours and temperature to $30^{\circ} \mathrm{C}$ [27]. But with further increase in temperature at $35^{\circ} \mathrm{C}$, VFAs production 
decreased, however, the amount of VFAs generated was enough for using in BNR process [27].

Effect of HRT on VFAs production was studied in a CMR using diluted PS [6]. VFAs and SCOD concentration as well as specific VFAs production rate were found maximum at the temperature of $25^{\circ} \mathrm{C}, \mathrm{HRT}$ of 30 hours, and a SRT of 10 days [6]. Specific VFAs production rate at the $\mathrm{HRT}=30$ hours and a temperature of $25^{\circ} \mathrm{C}$ was $0.0306 \mathrm{mg}$ VFAs $\mathrm{g}^{-1} \mathrm{VSS} \mathrm{d}^{-1}[6]$. HAc was the dominant VFAs produced with an average percentage content of $61-67 \%$, followed by $\mathrm{HPr}(24-35 \%)$ [6].

Two bench scale fermenters were used to analyze the effect of PS fermentation on VFAs production [8]. Experiments were conducted at a SRT of 4-10 days, total volatile solids concentration of $0.6-2.8 \%$, and under two different temperatures of $20^{\circ} \mathrm{C}$ and $30^{\circ} \mathrm{C}$ [8]. The results from this study indicated the importance of feed sludge characteristics on VFAs yield. High VFAs yield was observed at high total volatile solids concentrations above $23,000 \mathrm{mg} \mathrm{l}^{-1}$ [8]. When SRT increased from 4 days to 6 days, a significant decrease in VFAs yields was observed [8]. Increasing the temperature increased the VFAs yields dominantly as a result of improved hydrolysis of particulate organic matter [8].

The effect of SRT in a range of 3-15 days was investigated on PS hydrolysis, acidification and methanogenesis [20]. The research demonstrated that SRT $\leq 8$ days resulted in acidogenic conditions with negligible biogas production, whereas SRT $\geq 8$ days resulted in methanogenic conditions [20]. The hydrolysis of carbohydrate and lipids increased as SRT increased [20]. 


\subsubsection{Effect of Temperature}

PS fermenters have been operated at ambient and controlled temperatures in various studies. It was observed that when temperature increases, hydrolysis, and acidification of PS improves [25]. It was reported that temperature had a significant effect on the hydrolysis of protein, carbohydrate, and lipids content of PS. Hydrolysis rate was higher at $35^{\circ} \mathrm{C}$ than $25^{\circ} \mathrm{C}$ [10]. Additionally, a higher rate of hydrolysis was observed at $55^{\circ} \mathrm{C}$, compared to PS fermentation at $20^{\circ} \mathrm{C}$ and $35^{\circ} \mathrm{C}$ [35]

Production of VFAs had been studied in various temperature ranges and found that if the temperature is increased within psychrophilic $\left(12-18^{\circ} \mathrm{C}\right)$ and mesophilic temperature ranges $\left(25-40^{\circ} \mathrm{C}\right)$, the concentration of VFAs production increases [36]. In addition, the rate of the VFAs production will increase [6]. The study shows that VFAs yield also increases with temperature [8]. By increasing the temperature from 10 to $35^{\circ} \mathrm{C}$, the VFAs concentration from WAS increased by $30 \%$ [37]. In the case of the fermentation of PS, VFAs concentration rate improved six-fold as the temperature was increased from 8-25 ${ }^{\circ} \mathrm{C}$ [6]. It has been reported that thermophilic temperatures lead to faster biodegradation and more active acidogenesis compared to that of mesophilic temperature [38]. A batch experiment conducted on activated sludge with $1 \%$ glucose showed that at $\mathrm{pH} 5.0$ and 6.0, the higher the temperature, the higher the fermentation rate is as microbial metabolism increased with the increasing temperatures [39].

It has been observed that VFAs production from PS consistently improved with the temperature increase from $10^{\circ} \mathrm{C}$ to $30^{\circ} \mathrm{C}$ [16]. However, at $30^{\circ} \mathrm{C}$ and under uncontrolled $\mathrm{pH}$ and HRT of 9 days, the net VFAs production dropped from $115 \mathrm{mg} \mathrm{l}^{-1}$ as $\mathrm{HAc}$ at $20^{\circ} \mathrm{C}$ to $103 \mathrm{mg} /$ as $\mathrm{HAc}$ at $30^{\circ} \mathrm{C}$ [40]. Temperature effect on VFA production was also studied 
for PS fermentation in a temperature range of $10-24^{\circ} \mathrm{C}$ [29]. According to this study, the VFA production increases significantly because of temperature increase. At $10^{\circ} \mathrm{C}, 610$ $\mathrm{mg} \mathrm{l}^{-1}$ VFAs was produced, while it increased to $2950 \mathrm{mg} \mathrm{l}^{-1}$ at $24{ }^{\circ} \mathrm{C}$ [29]. The effect of SRT and process temperature on the hydrolysis and acidification of PS was investigated in CSTR reactors. The SRT and temperature have a substantial effect on the hydrolysis of protein, carbohydrates, and lipids [10]. The hydrolysis rate constant of all solid substance was significantly affected by temperature [10]. Biodegradability of PS shows no temperature dependency for a range of $15-35^{\circ} \mathrm{C}[10]$.

The above studies recapitulate the fact that increasing the fermentation temperature rises the production of VFAs as the kinetics and rate of reaction is increased. Higher temperature such a thermophilic temperature range is most likely require less HRT for higher VFAs production.

\subsection{Alkaline fermentation of PS sludge}

Alkaline fermentation of sewage sludge can also be applied for enhanced VFAs production from PS. As opposed to using caustic soda or other chemicals to achieve alkaline $\mathrm{pH}$ that causes higher cost, the anaerobic supernatant can be used to adjust $\mathrm{pH}$ of the fermenter. The effects of mesophilic $\left(35^{\circ} \mathrm{C}\right)$ and thermophilic $\left(55^{\circ} \mathrm{C}\right)$ temperatures, retention time (1- 8 days), $\mathrm{pH}(8.0-11.0)$ and initial TS concentrations $(4.5-6.5 \%)$ have been studied in various studies to optimize the VFAs production under alkaline fermentation. Similar results were obtained in terms of VFA production when anaerobic fermenter supernatant of sludge was used for $\mathrm{pH}$ adjustment compared to the caustic soda. The highest VFA concentration was achieved at $\mathrm{pH} 10.0$ and 11.0, TS 6.5\%, and a SRT of 6 days under a temperature of $55^{\circ} \mathrm{C}$ [41]. Design conditions for the batch test 
was as follows: temperature: $35^{\circ} \mathrm{C} \& 55^{\circ} \mathrm{C}, \mathrm{pH}: 8.0-11.0$, retention time: 1 - 8 days, initial TS: $4.5 \%$ \& $6.5 \%$. The VFAs concentration of $122 \mathrm{mg} \mathrm{COD} \mathrm{g}^{-1} \mathrm{VS}$ fed was obtained at $\mathrm{pH}=8 \& 9$, retention time $6-7$ days, $\mathrm{TS}=6.5 \%$, and temperature of $37^{\circ} \mathrm{C}[41]$. The VFA concentration was increased to $298 \mathrm{mg} \mathrm{COD} / \mathrm{g}$ VS fed (2.5 times higher) at $\mathrm{pH}=10$ \& 11 , retention time 6 days, TS $=6.5 \%$, Temperature $55^{\circ} \mathrm{C}[41]$.

The effect of $\mathrm{pH}$ ranging from 5.0 to 12.0 on PS fermentation for VFA production was examined [42]. The experiment result indicated that hydrolysis was accelerated and sludge solubilization was greatly enhanced as high concentrations of SCOD were produced at alkaline $\mathrm{pH}$ conditions [43]. The study also demonstrated a decrease in VFAs production due to inhibition of acidification in extremely alkaline conditions of $\mathrm{pH} 11.0-$ 12.0 [43]. However, between pH 8.0 and 9.0, more VFAs accumulation was observed, even though SCOD production was less compared to extreme alkaline conditions [43]. HAc and HPr were dominant constituents for VFA produced in this study.

The mechanism for VFAs accumulation through PS fermentation has been examined [44]. The result indicated that highest VFAs yield (312.9 $\mathrm{mg} \mathrm{COD} \mathrm{g}^{-1} \mathrm{VSS}$ ) was achieved at $\mathrm{pH} 10.0$ to 11.0 over five days retention time [44]. Composition and distribution of the VFAs generated from PS was HAc $49.4 \%, \mathrm{HPr} 34.4 \%$, iso-HBu $14.6 \%$, and $\mathrm{n}-\mathrm{HBu} 12.2 \%$ [44]. VFAs production at $\mathrm{pH} 10$ was 1.8 times higher than that of neutral and acid $\mathrm{pH}$. Maximum yield of SCOD (5755 $\mathrm{mg} \mathrm{l}^{-1}$ or $343 \mathrm{mg} \mathrm{SCOD} \mathrm{g}^{-1}$ VSS) was achieved at $\mathrm{pH} 10.0$ [45]. The SCOD yield (4003 $\mathrm{mg} \mathrm{l}^{-1}$ or $192.8 \mathrm{mg} \mathrm{SCOD} / \mathrm{g} \mathrm{VSS}$ ) at $\mathrm{pH}$ of 7.0 was 1.8 times higher than the yield of SCOD (3755 $\mathrm{mg} \mathrm{l}^{-1} 173.2 \mathrm{mg} \mathrm{SCOD)} \mathrm{at} \mathrm{pH} \mathrm{of} 4.0$ [44]. 


\subsection{Application of VFAs}

The primary application of VFAs are as follows:

a) Bioplastics production - polyhydroxyalkanoates $(\mathrm{PHA})$ are biodegradable polymers which are created by microorganisms using VFAs [3]. PHA is environment-friendly and has widespread applications in the industry that substitutes petrochemical-based plastics with high production cost [3].

b) Generation of Bioenergy - In the current world of the energy crisis, the waste-derived VFAs can be considered an alternative source for producing bioenergy [3]. For example, it is possible to generate electricity from PS derived VFAs using a microbial fuel cell [3]. VFAs can also be used to yield fuels such as biogas, hydrogen, and biodiesel [3].

c) Biological Nutrient Removal (BNR) process - Additional carbon substrates like VFAs are required for stable BNR process because the carbon substrate in treated municipal wastewater is insufficient to remove $P$ and $N$ [3]. Carbon to nitrogen requirement should be $5-10 \mathrm{mg} \mathrm{COD} / \mathrm{mg} \mathrm{N}$ for combined nitrification /denitrification process [19]. A range of 7.5-10.7 $\mathrm{mg}$ COD required to remove $1 \mathrm{mg}$ of $\mathrm{P}$. PS derived VFAs is more economical than using synthetic VFAs [46]. For the BNR process, the success criterion is to provide enough biodegradable organic substance. The substrates can be supplied to biomass by either dosing chemicals or by exploiting internal carbon sources of the system [3]. Hydrolysis and acid fermentation converts the particulate and slowly soluble biodegradable substances of PS into readily biodegradable substrates such as VFAs. Feasibility of using the VFAs produced through the mesophilic fermentation of PS on the BNR process was investigated by 
[47]. The results of this study showed that the denitrification efficiency increased by $4-10 \%$ after the addition of VFAs as a carbon source [47].

\section{Materials and Methods}

\subsection{PS and inoculum source}

The PS that was used in this work was collected from Ashbridge's wastewater treatment plant (ABWWTP). ABWWTP is the largest of four wastewater treatment plants operated by the City of Toronto. Located in Toronto's east end, the plant has a nominal treatment capacity of $818,000 \mathrm{~m}^{3} \mathrm{day}^{-1}$ and serves an equivalent population of $1,524,000$. The average daily influent flow rate in 2016 was $549.8 \mathrm{ml} \mathrm{day}^{-1}$ [48]. Raw wastewater flows into two preliminary treatment facilities where grit and screenings are removed. There are twelve Primary Clarifiers with a total installed peak flow capacity of 2,730,999 $\mathrm{m}^{3} /$ day. The inoculum was also collected from the digester in the same plant. The PS and TWAS are mixed at the ratio of 1:4 (by volume) and the mixed sludge stream is then fed to twenty digesters operated at the mesophilic condition $\left(34-38^{\circ} \mathrm{C}\right)$. The average SRT and OLR of the digesters are $18.1 \mathrm{~d}$ and $1.1 \mathrm{~kg} \mathrm{VS} \mathrm{m}^{-3}$.

Characteristics of PS used in the batch test for bench scale experiment has been shown

in Table 3. The mean value of TSS and VSS concentration of PS were $36,005 \mathrm{mg} \mathrm{l}^{-1}$ and $28,723 \mathrm{mg} \mathrm{l}^{-1}$, respectively. TCOD and SCOD were 53,386 $\mathrm{mg} \mathrm{l}^{-1}$ and $3016 \mathrm{mg} \mathrm{l}^{-1}$, respectively. The ratio of mean SCOD/TCOD ratio was $5.6 \%$, and VFAs/SCOD ratio was $42 \%$. 
Table 3 Characteristics of feed PS used in batch fermentation studies

\begin{tabular}{|l|l|l|l|}
\hline Parameter & units & Mean & Std Dev \\
\hline $\mathrm{pH}$ & & 5.6 & 0.11 \\
\hline TSS & $\mathrm{mg} \mathrm{l}^{-1}$ & 36,000 & 5,179 \\
\hline $\mathrm{VSS}$ & $\mathrm{mg} \mathrm{l}^{-1}$ & 28,300 & 4,340 \\
\hline $\mathrm{NH}_{3}-\mathrm{N}$ & $\mathrm{mg} \mathrm{l}^{-1}$ & 35 & 7 \\
\hline Alkalinity & $\mathrm{mg} \mathrm{CaCO}_{3} \mathrm{l}^{-1}$ & 675 & 322 \\
\hline TCOD & $\mathrm{mg} \mathrm{l}^{-1}$ & 53,400 & 6,208 \\
\hline SCOD & $\mathrm{mg} \mathrm{l}^{-1}$ & 3,000 & 90 \\
\hline TBOD & $\mathrm{mg} \mathrm{l}^{-1}$ & 21,200 & 5,296 \\
\hline VFAs & $\mathrm{mg} \mathrm{COD} \mathrm{l-1}^{-1}$ & 1,266 & 99 \\
\hline
\end{tabular}

\subsection{Experimental Setup}

Both batch and semi-continuous flow experiments were conducted in a cylindrical shape anaerobic fermenter with $4 \mathrm{~L}$ working volume capacity, see Figure 10. Each fermenter has temperature display with a temperature probe submerged in the liquid. The temperature was controlled using a water heating bath. Plastic tubing from the water tank was wrapped around the digesters, and the reactor then covered with reflective material to retain heat. The water bath was set up to heat the containing water to $50^{\circ} \mathrm{C}$ to ensure that the internal reactor temperature was $35 \pm 2^{\circ} \mathrm{C}$. The reactor has a propeller connected with the shaft and rotated by a NEMA 17 motor to provide the required mixing. The $\mathrm{pH}$ in the fermenter was controlled using a $\mathrm{pH}$ probe at the bottom of the reactor and connected to a $\mathrm{DLX} \mathrm{pH}-$ $\mathrm{RX} / \mathrm{MBB}$ meter pump with a display showing the $\mathrm{pH}$. A schematic diagram of the experimental set up is displayed in the below Figure 3 and Figure 4. 


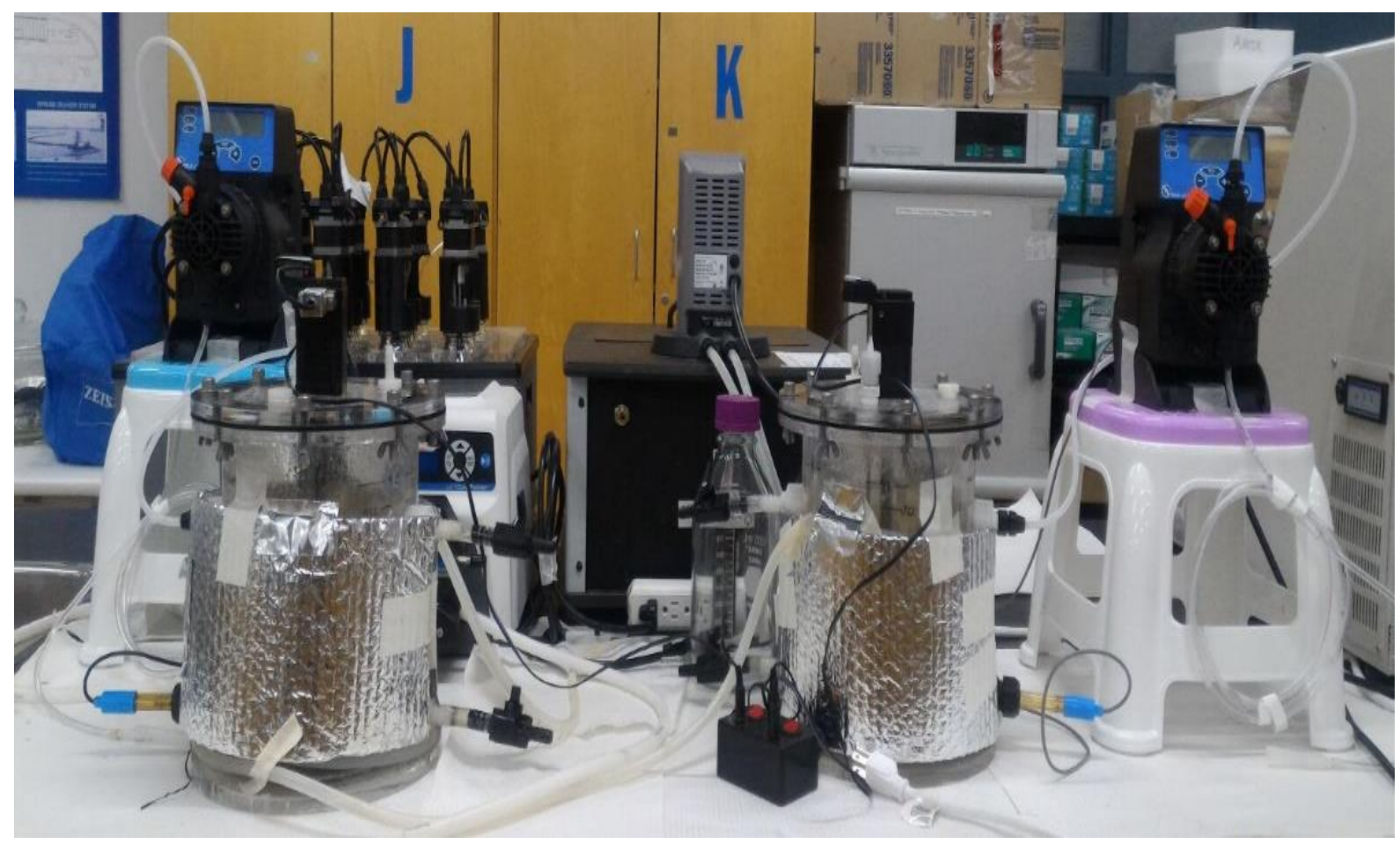

Figure 3 Photograph for bench scale PS anaerobic acid fermentation experimental set up

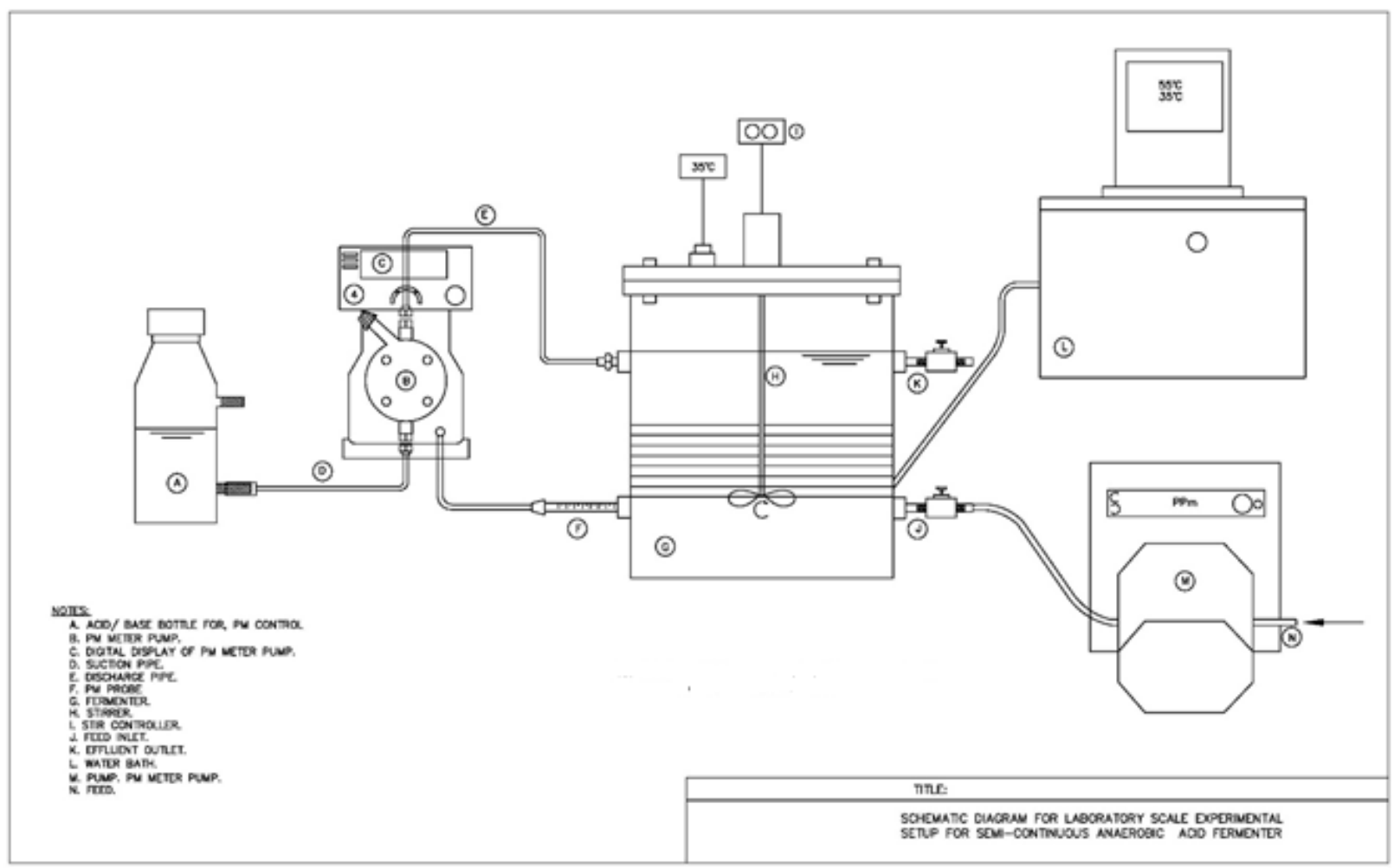

Figure 4 Schematic diagram for a bench scale experimental setup for PS anaerobic acid fermentation 


\subsection{Batch experiments}

The batch tests were conducted in a $4 \mathrm{~L}$ reactor with $3 \mathrm{~L}$ working volume at mesophilic temperature $\left(35^{\circ} \mathrm{C}\right)$. One Liter of PS was added to two liters of seed. Batch tests run at 7 different $\mathrm{pH}$ conditions $4.5,5.5,6.5,8.0,9.0,10.0$, and 11.0. Each experiment runs for three days, and the samples were collected and analyzed every 24 hours $(24,48$, and 72 hrs). Each sample was analyzed in triplicate.

\subsection{Semi-continuous experiments}

The semi-continuous flow experiments were conducted using three fermenters (working volume of $4 \mathrm{~L}$ ). Three different SRT of 1 day, 2 days, and 3 days were tested at three different $\mathrm{pH}$ values of $4.5,5.5$, and 6.5 . The feed and effluent volume was calculated based on the SRT, Master flex L/S digital pump system and Master Flex C-flex tubing were used for feeding the PS and collecting the effluent. The semi-continuous process was run for three times the designed HRT for start-up period, after that steady state starts to reach. As soon the steady state reaches the reactor run for more for three times the designed HRT duration. During the steady state period, the liquid samples (6 samples for each run) were collected. The $\mathrm{pH}$ and temperature of the effluent samples were measured immediately, poured into plastic $250 \mathrm{~mL}$ sample bottles, and placed in the refrigerator below $4^{\circ} \mathrm{C}$ until analysis was completed.

\subsection{Feeding substrate and collecting effluent semi-continuous study}

While running a semi-continuous system, the effluent is always collected before feeding the system. The volume collected should equal quantity fed. For this semi-continuous study working volume was $4 \mathrm{~L}$. Every day while the experiment continues $2 \mathrm{~L}$ of effluent 
was collected, and then $2 \mathrm{~L}$ of PS fed to the system through the feed pump. The system was kept well mixed throughout the total reaction time. Routine was kept consistent each day.

The amount collected and fed to the system each day will depend on the system working volume and required HRT as per equation (8).

For HRT of 1 day or less, the system will need to be fed twice or more each day as per equation (8).

The terminology HRT can be used instead of SRT for a continuous flow system anaerobic acid fermentation process. For Suspended Growth, Continuous Stirred Tank Reactor (CSTR) HRT can be considered same as SRT, as flow rate (Q), Qin is equal to Qout and Total Suspended Solids (TSS), TSS in=TSS out.

The effluent was collected from the bottom sprout; the substrate was fed through the top sprout. While obtaining the effluent sample, the outlet sprout valve was opened, and the effluent sample was collected. Whereas while supplying, the tube was connected through the pump with one side with feed inlet jar and another side with the reactor inlet sprout. It was ensured that the valve was open before running the pump and the valve was shut before disconnecting the tubing. Out of total reaction time first six days was considered as a startup on the $7^{\text {th }}$ days until the entire reaction time total six effluent samples were collected from the fermenter every day for HRT of 1 day and 2 days and every consecutive day for HRT of 3 days. 


\subsection{Sample analysis}

The analyses that were performed are TSS, VSS, TCOD and SCOD, ammonia-nitrogen $\left(\mathrm{NH}_{3}-\mathrm{N}\right)$, alkalinity, $\mathrm{CBOD}$, VFAs. The samples were filtered through Acrodisc ${ }^{\circledR} 32 \mathrm{~mm}$ Syringe filter with $0.45 \mu \mathrm{m}$ Supor $^{\circledR}$ membrane, to perform the soluble analysis. All analyses were carried out in triplicates. The $\mathrm{pH}$ for each sample was measured immediately using VWR Benchtop $\mathrm{pH}$ Meter and refillable glass probe, model B10P. Total and Volatile Suspended Solids was measured using methods 2540B and 2540E for TS and VS respectively [49]. Total and soluble COD was measured using COD reagent vials from $\mathrm{HACH}$, method 8000. Ammonia-Nitrogen was measured using the Amver Nitrogen Ammonia reagent set, method 10031. Alkalinity was measured with colorimetric method 10239 using TNT plus 870 Total Alkalinity test kit. Total VFAs were measured by the Esterification Method as per method 10240 at a range of $50-2500 \mathrm{mg} \mathrm{l}^{-1}$ as $\mathrm{CH}_{3} \mathrm{COOH}$ (Acetic Acid) using TNT plus ${ }^{\mathrm{TM}} 872$ Vials.

\subsection{Calculations}

Several calculations formulae used in the experiment has been described below

- The degree of solubilization batch experiment

$$
\begin{aligned}
& \text { Degree of solubilization }(\%)=\frac{\text { Mass of } S C O D_{\text {Produced }}}{p C O D_{\text {in }}} \times 100 \\
& \text { Mass of } S C O D_{\text {Produced }}=\left(S C O D_{\text {Effluent }}-S C O D_{\text {in }}\right) \times \text { Volume }_{\text {Total }} \\
& S C O D_{\text {in }}=\frac{S C O D_{P S} \times V_{P S}+S C O D_{\text {Seed }} \times V_{\text {seed }}}{V_{P S}+V_{\text {Seed }}} \\
& p C O D_{\text {in }}=\left(T C O D_{P S}-S C O D_{P S}\right) \times V_{P S}
\end{aligned}
$$


- Degree of solubilization semi-continuous experiment

Degree of solubilization $(\%)=\frac{\text { Mass increase in SCOD }}{p C O D_{\text {in }}} \times 100$

Mass increase in $S C O D=\left(S C O D_{\text {Effluent }}-S C O D_{\text {in }}\right)$

Particulate $p C O D_{\text {in }}=\left(T C O D_{\text {Effluent }}-S C O D_{\text {in }}\right)$

- VFAs yield

$$
\begin{gathered}
\text { VFAs Yield }=\frac{\text { VFAs Produced }}{P S \text { VSS feed }}=\frac{\frac{m g C O D}{l}}{\frac{m g V S S_{\text {feed }}}{1000 \times l}}=\frac{m g C O D}{g m V S S_{\text {feed }}} \\
=m g \text { COD } g^{-1} \text { VSS }_{\text {feed }} \ldots \ldots \ldots \ldots \ldots \ldots \ldots \ldots \ldots \ldots \ldots \ldots \ldots \ldots \ldots \ldots \ldots \ldots \ldots \ldots \ldots \ldots \ldots
\end{gathered}
$$

- SCOD yield

$$
\begin{aligned}
\text { SCOD Yield }= & \frac{\text { SCOD Produced }}{\text { PS VSS feed }}=\frac{\frac{m g S C O D}{l}}{\frac{m g V S S_{\text {feed }}}{1000 \times l}}=\frac{m g S C O D}{g m V S S_{\text {feed }}} \\
& =m g \text { SCOD } g^{-1} V_{S S} \text { feed } \ldots \ldots \ldots \ldots \ldots \ldots \ldots \ldots \ldots \ldots \ldots \ldots \ldots \ldots \ldots \ldots \ldots \ldots
\end{aligned}
$$

- VFAs/SCOD ratio

$$
\frac{V F A s}{S C O D}=\frac{V F A s \text { Produced }}{\text { SCOD Produced }}=\frac{\frac{m g C O D}{l}}{\frac{m g S C O D}{l}} \times 100=\%
$$




\section{Results and Discussion}

\subsection{Batch Experiments}

Batch tests were used to evaluate the effect of $\mathrm{pH}$ on both VFAs production and solubilization. Samples were collected on day 1,2 , 3 (i.e. after 24,48 , and $72 \mathrm{hr}$ ) to assess the impact of different HRTs of 1, 2, 3 days on the VFAs production and solubilization.

\subsubsection{VFAs production and Soluble COD}

Figure 5 shows the VFAs production during the fermentation of PS in a batch reactor. It reveals that with increasing HRT, VFAs production increased for all the pHs. However, VFAs production increased with increasing $\mathrm{pH}$ until pH 8.0 and then it starts to decrease. Comparing acidic and alkaline $\mathrm{pH}$ conditions, the results showed that the alkaline $\mathrm{pH}(\mathrm{pH}$ 8.0-11.0) produced higher VFAs compared to acidic $\mathrm{pH}$ range (pH4.5-6.5), $1954-2587$ $\mathrm{mg} \mathrm{COD} \mathrm{l}^{-1}$ for alkaline $\mathrm{pH}$ versus $1316-1852 \mathrm{mg} \mathrm{COD} \mathrm{l}^{-1}$ for acidic $\mathrm{pH}$. Maximum VFAs production was observed at $\mathrm{pH} 8.0$ for all the different HRTs. The maximum VFAs concentrations of 2587,1820 , and $1,455 \mathrm{mg} \mathrm{COD} \mathrm{l}^{-1}$ were achieved for HRTs of 1 day, 2 days, and 3 days, respectively. The VFAs production, normalized by mass of VSS added, ranged from 43 to $234 \mathrm{mg} \mathrm{COD} \mathrm{g}^{-1} \mathrm{VSS}_{\text {feed }}$ for $\mathrm{pH} 4.5-11$.

As shown in Figure 5, the SCOD increased with increasing the HRT for all pH values. The highest SCOD concentration of $10640 \mathrm{mg} \mathrm{l}^{-1}$ was achieved at $\mathrm{pH} 10.0$ and HRT 3 days. On the other hand, for all HRTs, the SCOD increased with increasing the $\mathrm{pH}$ values until $\mathrm{pH}$ 10.0, after which the SCOD decreased. The batch study data indicates that as the $\mathrm{pH}$ goes from acidic to alkaline solubilization of the substrate increases. 


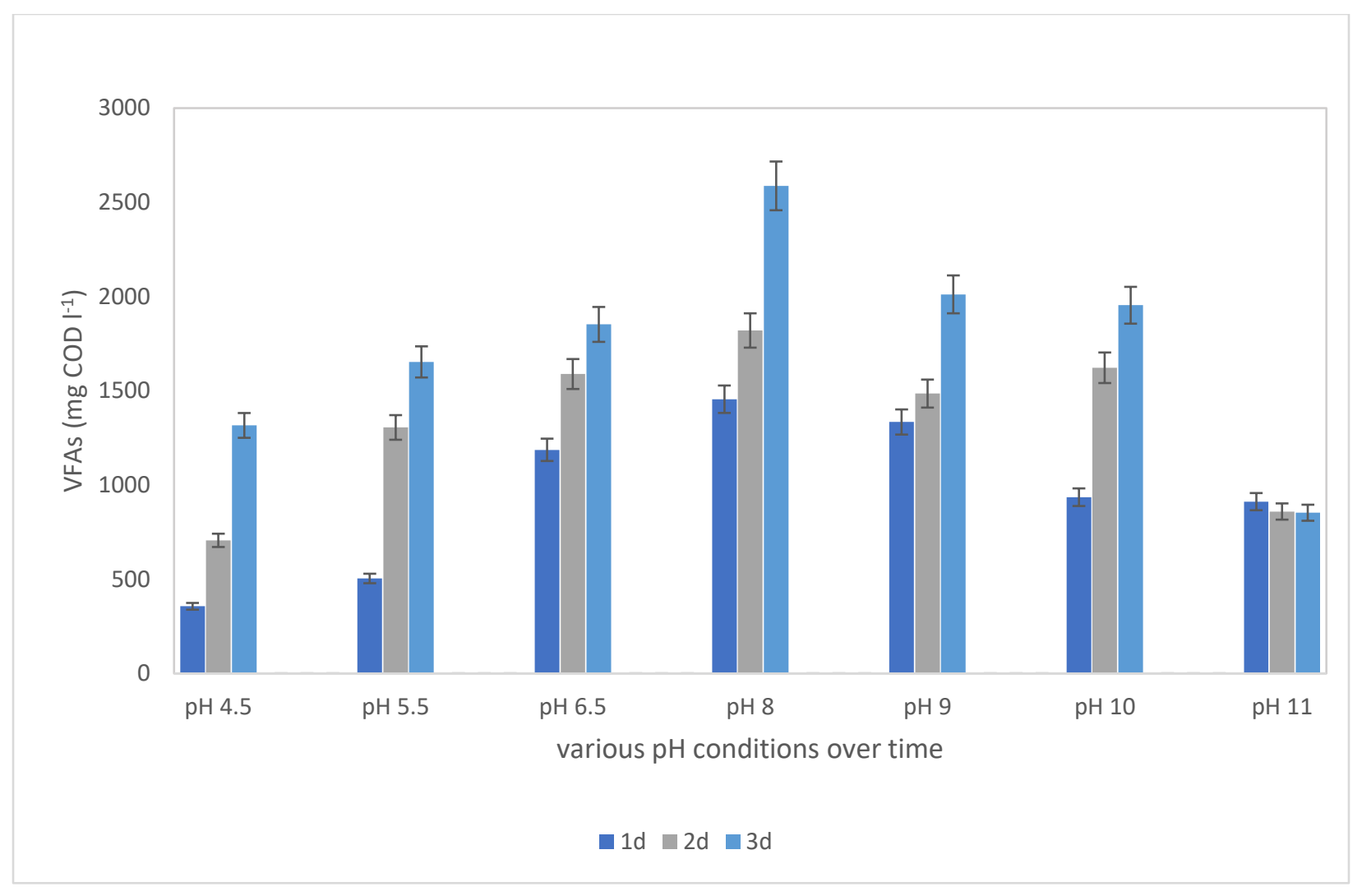

Figure 5 VFAs production during batch studies through PS anaerobic acid fermentation

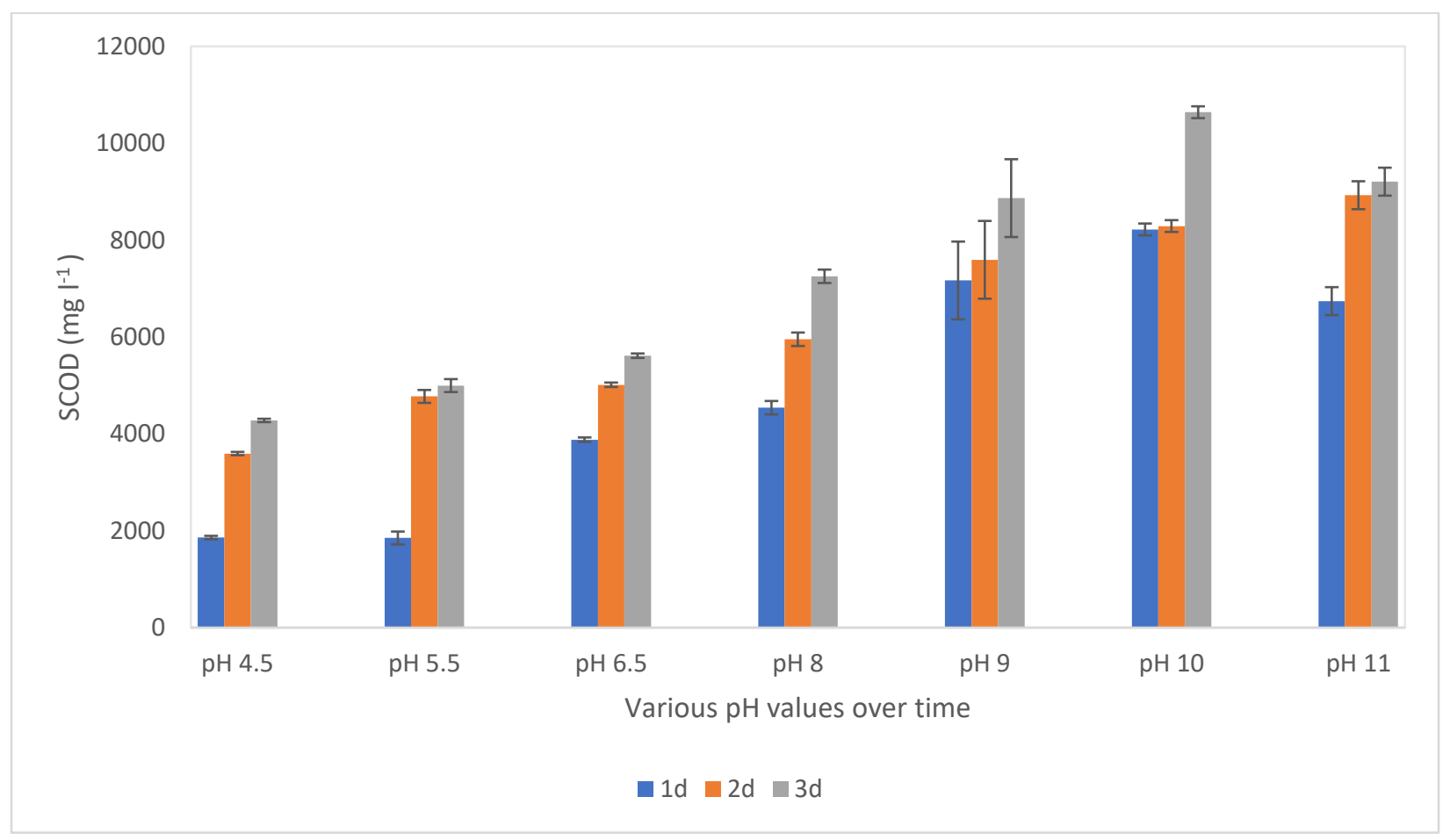

Figure 6 SCOD data for the batch experiment 


\subsubsection{The degree of solubilization}

One of the main advantages of anaerobic fermentation is the solubilization of particulate organic fractions and converting them into soluble substances. One of the primary indicators for the fermentation efficiency is the degree of solubilization. The degree of solubilization is the fraction of the particulate COD ( $p C O D)$ that converted into SCOD during the fermentation process. The degree of solubilization for the batch experiment was calculated using the equation (10).

Figure 7 shows the degree of solubilization for the different $\mathrm{pH}$ values at different HRTs. It demonstrates that the degree of solubilization ranged from $2.0 \%$ to 48.0 . The degree of solubilization increased with increasing the $\mathrm{pH}$ and reached a maximum of $48 \%$ at $\mathrm{pH}$ 10.0 and HRT 3 days. The maximum degree of solubilization for acidic $\mathrm{pH}$ of $30 \%$ was observed at $\mathrm{pH} 6.5$. For $\mathrm{pH} 5.5$, there were no significant differences between the degree of solubilization at HRTs 2 and three days. The results showed that the maximum degree of solubilization that achieved with acidic $\mathrm{pH}$ could be achieved with much shorter HRT at alkaline $\mathrm{pH}$. For example, to obtain a degree of solubilization of about $30 \%$ with acidic $\mathrm{pH}$, the HRT should be three days, however, to achieve the same degree of solubilization with alkaline $\mathrm{pH}, \mathrm{HRT}$ of only one day is required. 


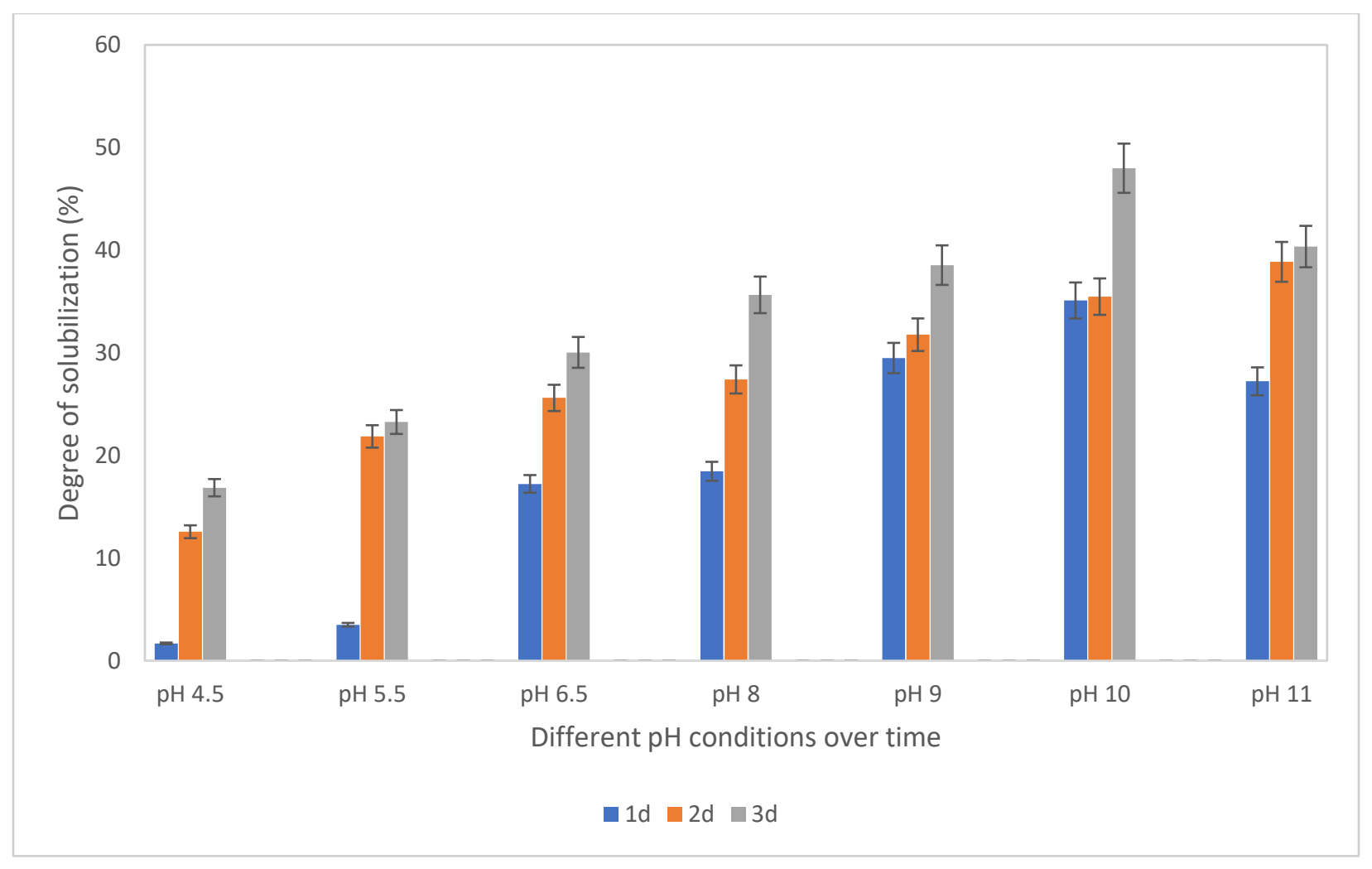

Figure 7 Degree of solubilization for the batch experiment

\subsubsection{VFAs yield, SCOD yield}

Due to the variable composition of the PS collected several times of the batch experiment, overall yield has been calculated to evaluate the acid fermentation potential. Both VFAs and SCOD yield have been calculated as the mass of VFAs and SCOD fermenter effluent produced per unit mass of VSS feed. The batch studies performed with PS indicates that the soluble COD produced during the fermentation is converted to VFAs, i.e., short chain fatty acids.

As shown in Table 4, the VFAs yield increased with increasing the HRT for all $\mathrm{pH}$ values. For acidic $\mathrm{pH}$, the VFAs yield increased with increasing the $\mathrm{pH}$ and reached a maximum of $222 \mathrm{mg} \mathrm{VFAs} \mathrm{g}^{-1} \mathrm{VSS}_{\text {feed }}$ at $\mathrm{pH} 6.5$ and HRT of 3 days. For alkaline $\mathrm{pH}$, there were no significant differences for $\mathrm{pH} 8,9$, and 10 . However, the yield dropped significantly at $\mathrm{pH}$ 
Table 4 Data for batch study, VFAs, SCOD, VFAs and SCOD yields for PS fermentation

\begin{tabular}{|c|c|c|c|c|c|c|c|c|c|}
\hline $\mathrm{pH}$ & Time & $\begin{array}{c}\text { PS } \\
\text { TSS }\end{array}$ & $\begin{array}{l}\text { PS } \\
\text { VSS }\end{array}$ & $\begin{array}{l}\text { Effluent } \\
\text { VFAs }\end{array}$ & $\begin{array}{l}\text { Effluent } \\
\text { SCOD }\end{array}$ & $\begin{array}{l}\text { VFAs/ } \\
\text { SCOD }\end{array}$ & VFAs yield & $\begin{array}{l}\text { SCOD } \\
\text { yield }\end{array}$ & $\begin{array}{c}\text { degree } \\
\text { of } \\
\text { solubili } \\
\text { zation }\end{array}$ \\
\hline & (d) & $\left(\mathrm{mg} \mathrm{l}^{-1}\right)$ & $\left(\mathrm{mg} \mathrm{l}^{-1}\right)$ & $\left(\mathrm{mg} \mathrm{COD}^{-1}\right)$ & $\left(\mathrm{mg} \mathrm{l}^{-1}\right)$ & $\begin{array}{c}\mathrm{mg} \mathrm{COD}_{\mathrm{mg}^{-1}} \\
\text { SCOD } \\
\%\end{array}$ & $\begin{array}{c}\text { (mg COD } \\
g^{-1} \text { VSSfeed) }\end{array}$ & $\begin{array}{c}\text { (mg SCOD } \\
g^{-1} \text { VSS } \\
\text { feed) }\end{array}$ & $\%$ \\
\hline 4.5 & 1 & 31889 & 24978 & 356 & 1880 & 19 & 43 & 226 & 2 \\
\hline 4.5 & 2 & 31889 & 24978 & 706 & 3593 & 20 & 85 & 432 & 13 \\
\hline 4.5 & 3 & 31889 & 24978 & 1316 & 4277 & 31 & 158 & 514 & 17 \\
\hline 5.5 & 1 & 31889 & 24978 & 504 & 1850 & 27 & 61 & 222 & 4 \\
\hline 5.5 & 2 & 31889 & 24978 & 1305 & 4773 & 27 & 157 & 573 & 22 \\
\hline 5.5 & 3 & 31889 & 24978 & 1653 & 4997 & 33 & 199 & 600 & 23 \\
\hline 6.5 & 1 & 32589 & 25011 & 1187 & 3800 & 31 & 142 & 456 & 17 \\
\hline 6.5 & 2 & 32589 & 25011 & 1589 & 5013 & 32 & 191 & 601 & 26 \\
\hline 6.5 & 3 & 32589 & 25011 & 1852 & 5613 & 33 & 222 & 673 & 30 \\
\hline 8.0 & 1 & 43189 & 34100 & 1455 & 4610 & 32 & 128 & 406 & 19 \\
\hline 8.0 & 2 & 43189 & 34100 & 1820 & 5953 & 31 & 160 & 524 & 27 \\
\hline 8.0 & 3 & 43189 & 34100 & 2587 & 7253 & 36 & 228 & 638 & 36 \\
\hline 9.0 & 1 & 32890 & 26130 & 1334 & 7000 & 19 & 153 & 804 & 29 \\
\hline 9.0 & 2 & 32890 & 26130 & 1485 & 7593 & 20 & 171 & 872 & 32 \\
\hline 9.0 & 3 & 32890 & 26130 & 2012 & 8867 & 23 & 231 & 1018 & 39 \\
\hline 10.0 & 1 & 32589 & 25011 & 935 & 8340 & 11 & 112 & 1000 & 36 \\
\hline 10.0 & 2 & 32589 & 25011 & 1622 & 8980 & 18 & 195 & 1077 & 39 \\
\hline 10.0 & 3 & 32589 & 25011 & 1954 & 10640 & 18 & 234 & 1276 & 48 \\
\hline 11.0 & 1 & 36700 & 29733 & 912 & 6740 & 14 & 92 & 680 & 27 \\
\hline 11.0 & 2 & 36700 & 29733 & 859 & 8927 & 10 & 87 & 901 & 39 \\
\hline 11.0 & 3 & 36700 & 29733 & 853 & 9207 & 9 & 86 & 929 & 40 \\
\hline
\end{tabular}

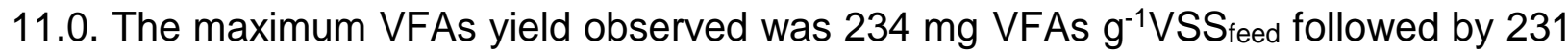
mg VFAs $\mathrm{g}^{-1} \mathrm{VSS}_{\text {feed }}$ both were corresponding to HRT of 3 days and $\mathrm{pH} 10.0$ and $\mathrm{pH}$ 9.0, 


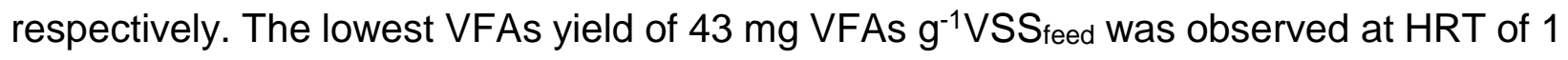
day and $\mathrm{pH} 4.5$.

Figure 8 shows the SCOD yield normalized per mass of VSS added. It shows that the SCOD yields increased with increasing the $\mathrm{pH}$ and reached a maximum of $1276 \mathrm{mg}$ SCOD $\mathrm{g}^{-1}$ VSS at $\mathrm{pH} 10$ and HRT of 3 days, after which it dropped to about $900 \mathrm{mg}$ SCOD

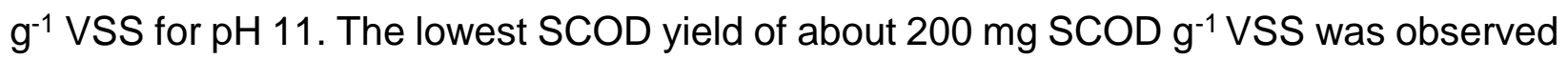
at $\mathrm{pH} 4.5$ and HRT of 1 day. The SCOD yields for all alkaline $\mathrm{pH}$ values (except $\mathrm{pH} 8.0$ ) were higher than those for acidic $\mathrm{pH}$.

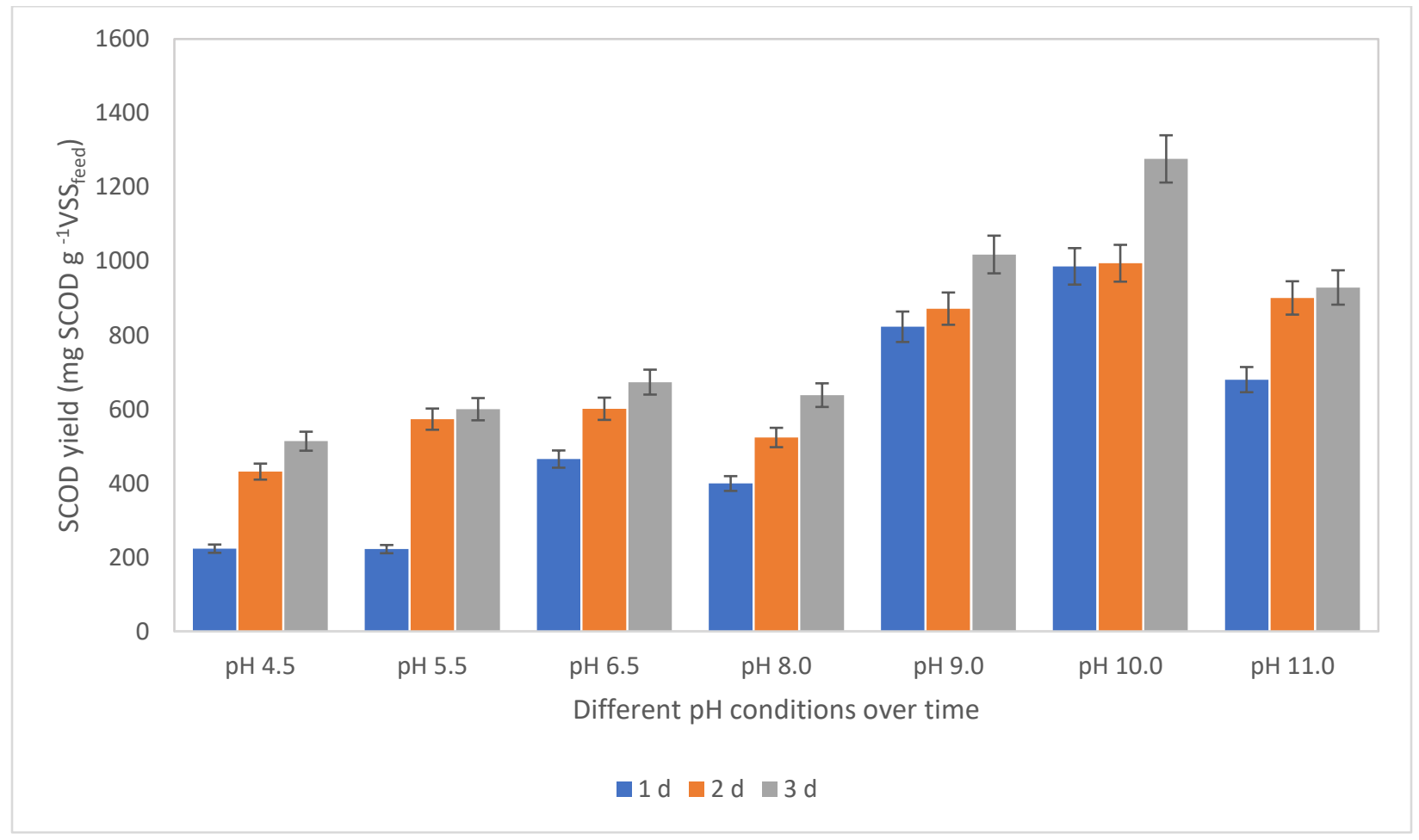

Figure 8 SCOD yield subject to VSS feed in batch studies of acid fermentation of PS

Figure 9 illustrates the ratios of VFAs to SCOD for the different operating conditions. As depicted in the figure, VFAs/SCOD ratios for acidic $\mathrm{pH}(4.5-6.5)$ were higher than those for alkaline $\mathrm{pH}(9.0-11.0)$. The VFAs/SCOD ratio ranged from $9 \%$ to $36 \%$. The maximum 
VFAs/SCOD ratio of $36 \%$ was achieved at $\mathrm{pH} 8.0$ and $\mathrm{HRT}$ of 3 days. For most $\mathrm{pH}$ values, except $\mathrm{pH} 10.0$ and 11.0, there was no significant difference between HRT 1 and two days. However, this ratio was higher for HRT of 3 days at all $\mathrm{pH}$ values except $\mathrm{pH} 11.0$.

In contradicting with most of the results observed in this study, for $\mathrm{pH} 11.0$, the VFAs/SCOD ratio at HRT of 1 day was higher than those for 2 and 3 days. The highest VFAs/SCOD ratio achieved for acidic $\mathrm{pH}$ was about $32 \%$, this ratio was observed at HRT of 3 days regardless of the $\mathrm{pH}$ ( 4.5 or 5.5 or 6.5 ). The highest VFAs/SCOD ratio achieved for alkaline $\mathrm{pH}$ was about $23 \%$, this ratio was observed at $\mathrm{HRT}$ of 3 days and $\mathrm{pH} 9.0$. The results also demonstrated an increasing pattern on VFAs/SCOD ratio with increasing the HRT for all the $\mathrm{pH}$ values except 11.0 .

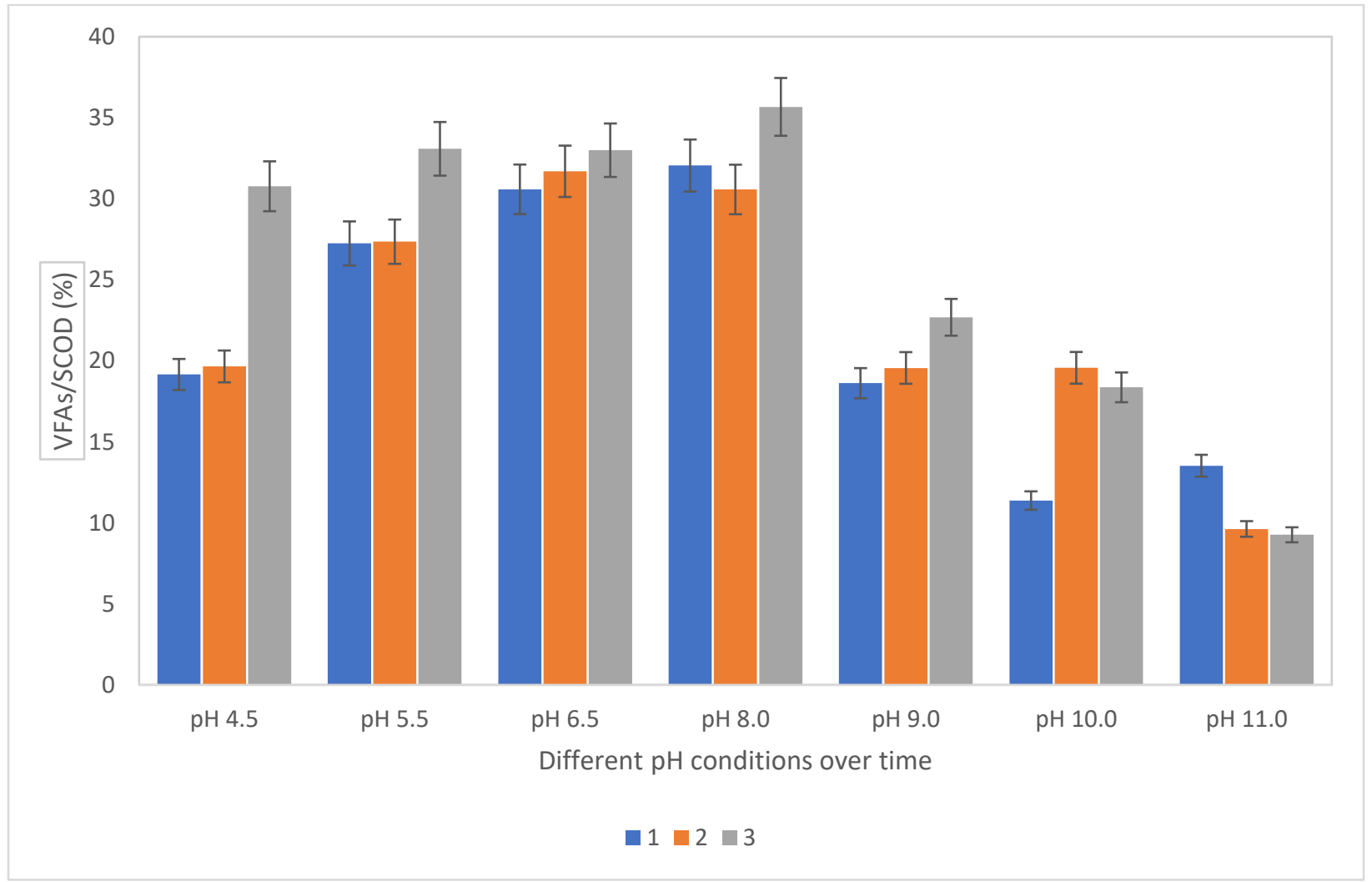

Figure 9 VFAs/SCOD as a percentage for acid fermentation of PS in batch studies 
Previous experiment results support the fact that $\mathrm{pH}$ significantly impacts fermentation efficiency of the fermenter and plays a vital role on anaerobic solubilization of PS. pH performs a significant function in increasing the production rate of VFAs as well VFAs yield regarding VFAs produced per unit mass VSS added. This batch study reveals that at a $\mathrm{pH}$ level of 8.0, VFAs accumulation was maximum. Whereas the other experimental study supports that maximum VFAs accumulation was obtained at $\mathrm{pH} 10.0$, where alkaline fermentation of PS for SCFAs was studied [44]. This experiment result reveals that $\mathrm{pH}$ range 8.0-10.0 caused higher VFAs production than $\mathrm{pH}$ range $4.5-6.5$. Between $\mathrm{pH}$ range $4.5-10.0$, VFAs yield increased rapidly with fermentation time, i.e., HRT and reached maximum on HRT 3 days. Further increase in $\mathrm{pH}$ did not result in an increase of VFAs production at HRT 3 days, somewhat decreased for $\mathrm{pH} 11.0$.

The above result reveals the fact that though VFAs production was maximum at $\mathrm{pH} 8.0$ $2587 \mathrm{mg} \mathrm{COD} \mathrm{l}^{-1}$ (SCOD $7253 \mathrm{mg} \mathrm{l}^{-1}$ ) in comparison to that of $\mathrm{pH} 10.0$,VFAs $1954 \mathrm{mg}$ $\operatorname{COD~l}^{-1}$ (SCOD $10640 \mathrm{mg} \mathrm{l}^{-1}$ ) but VFAs yield (mg COD g${ }^{-1} V_{S S}$ feed $)$ achieved maximum when fermentation $\mathrm{pH}$ was 10.0 with a value of $234 \mathrm{mg} \mathrm{COD} \mathrm{g}^{-1} \mathrm{VSS}_{\text {feed }}$.The reason for lesser VFAs production at $\mathrm{pH} 11.0$ and 4.5 during HRT 1-3 days was due to inhibition of acidogenic bacteria to extreme alkaline and acidic condition [44].

\subsubsection{Discussion of batch experiment results}

According to literature studies, production of VFAs depends more on HRT than temperature [50]. With an increment of HRT, the acidogens get more contact time to convert the waste, i.e., particulate organic carbon matters into soluble matters which favors the VFAs yield [1]. HRT of the system depends on the type, composition, and solid content of the substrate [51]. HRT favors the production of VFAs up to a specific value 
while prolonged HRT up to five days causes accumulation of VFAs in the fermenter. VFAs yield does not have any significant difference for HRT of 3 days and $\mathrm{pH} 6.5-10.0$ with $\mathrm{p}$ value ranging $0.303-0.993$ i.e., $\geq 0.05$ (appendix $C$ ). The batch study reveals the fact that VFAs yield increased as time increases from 1 day to 3 days. VFAs yield for batch experiment has significant difference over time (1 day -3 days) with $p$ value ranging $p \leq$ 0.05 (appendix $\mathrm{C}$ ). Methanogens grow at a slower rate than acidogens when the substrate is particulate organics. It is essential to operate the process at low SRT, preferably less than five days for better performance of the fermenter. If the SRT is low, it does not allow methanogens to grow and consumes the VFAs and convert them to methane and carbon dioxide [3]. The results of this batch study indicate the VFAs accumulation increases with time and no gas production was observed.

Previous researchers reported that fermentation of $\mathrm{PS}$ at higher $\mathrm{pH} 6.5-10.0$ caused higher VFAs accumulation than at $\mathrm{pH}$ 4.5-5.5 [44]. This study showed a similar pattern of VFAs yield supporting the literature claim. Henceforth, it became essential to analyze the mechanism of VFAs accumulation under alkaline condition.

Hydrolysis is the rate-limiting step for anaerobic fermentation which can be expressed by the change in SCOD [52]. Figure 8 displays changes in SCOD yield for PS hydrolysis for 3 days of fermentation time.

$\mathrm{pH}$ has significant impact on SCOD yield as $\mathrm{p}$ value $\leq 0.05$ (appendix $\mathrm{C}$ ). A per statistical analysis there is no significant difference on SCOD yield on 3 days reaction time over $\mathrm{pH}$ 5.5, 6.5 and 8.0 with $p$ value ranging 0.295 - 0.956 i.e., $p>0.05$ (appendix C). However, there is significant difference on SCOD yield on 3 days reaction time for $\mathrm{pH} 4.5,9.0,10.0$, 11.0 as $p$ value $\leq 0.05$ (appendix $C$ ). The SCOD yield shows a gradually increasing trend 
for $\mathrm{PS}$ fermentation at 3 days reaction time at different $\mathrm{pH}$ conditions which is also evident in statistical analysis with $p$ value $\leq 0.05$ (appendix $C$ ). The data reveals that the alkaline state prompts more solubilization of organic matter over acidic condition.

VFAs/SCOD ratio is an indicator of acidogenic activity [27]. VFAs/SCOD ratio at different $\mathrm{pH}$ conditions for HRT of 3 days is shown in Figure 9. The previous research reported that the VFAs/SCOD ratio was higher in alkaline $\mathrm{pH}$ than that of an acidic $\mathrm{pH}$ condition, i.e., the degree of acidification was higher in alkaline $\mathrm{pH}$ conditions [44].

On the other hand, this batch experiments showed that the VFAs/SCOD ratio of $19-36 \%$ was higher for $\mathrm{pH}$ range $4.5-8.0$, compared to $9-23 \%$ for $\mathrm{pH}$ range 9.0-11.0. The reason for this result is that the higher SCOD was produced at alkaline $\mathrm{pH}$ while higher VFAs was produced at acidic $\mathrm{pH}$. Hence while calculating the VFAs/SCOD percentage the denominator being a more substantial value than the numerator ratio becomes lower during alkaline $\mathrm{pH}$ condition.

\subsection{Semi-continuous Experiment}

Based on the result of the batch experiment of PS fermentation for VFAs production, it was observed that the VFAs yield was more for $\mathrm{pH} 6.5-10.0$. VFAs yield $(222-234 \mathrm{mg}$

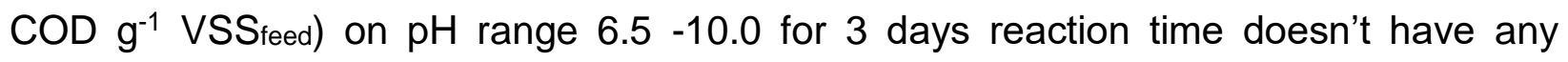
significant difference. On the other hand, as the $\mathrm{pH}$ moves upward to alkaline condition 8.0 -10.0, solubilization of PCOD to SCOD increases which is evident from SCOD concentration and degree of solubilization data. The primary objective of this study is to maximize the VFAs production. The $\mathrm{pH}$ of $\mathrm{PS}$ is around 5.5-6.8, to raise the $\mathrm{pH}$ and to conduct the experiment to satisfy the objective $\mathrm{pH} 6.5$ has been chosen. Raising the $\mathrm{pH}$ 
to 6.5 consumes less chemical and incurs less cost than it requires for $\mathrm{pH} 10.0$. The semi-continuous experiments were designed to investigate the effect of three different HRTs of 1 day, 2 days, and 3 days and three acidic $\mathrm{pH}$ values of $4.5,5.5$ and 6.5. Table 5 shows the operating and environmental conditions of the semi-continuous experiment.

Table 5 Semi-continuous experiments conditions.

\begin{tabular}{|c|c|c|c|c|}
\hline Run & Temp & HRT (d) & $\mathrm{pH}$ & Minimum duration of the run (d) \\
\hline Run 1 & $(35 \pm 3)^{\circ} \mathrm{C}$ & 1 & 4.5 & 9 \\
\hline Run 2 & $(35 \pm 3)^{\circ} \mathrm{C}$ & 2 & 4.5 & 12 \\
\hline Run 3 & $(35 \pm 3)^{\circ} \mathrm{C}$ & 3 & 4.5 & 9 \\
\hline Run 4 & $(35 \pm 3)^{\circ} \mathrm{C}$ & 1 & 5.5 & 12 \\
\hline Run 5 & $(35 \pm 3)^{\circ} \mathrm{C}$ & 2 & 5.5 & 18 \\
\hline Run 6 & $(35 \pm 3)^{\circ} \mathrm{C}$ & 3 & 5.5 & 12 \\
\hline Run 7 & $(35 \pm 3)^{\circ} \mathrm{C}$ & 1 & 6.5 & 18 \\
\hline Run 8 & $(35 \pm 3)^{\circ} \mathrm{C}$ & 2 & 6.5 & 9.5 \\
\hline Run 9 & $(35 \pm 3)^{\circ} \mathrm{C}$ & 3 & & \\
\hline
\end{tabular}

5.2.1 Characteristics of feed stock i.e., PS

For the semi-continuous study, PS was collected from Ashbridge's Bay WWTP on a weekly basis and stored in a refrigerator at $4^{\circ} \mathrm{C}$. Characteristics of feed PS used in semicontinuous bench scale experiment is shown in Table 6. The mean value of TSS and VSS concentration of PS were in the typical range $34,000 \mathrm{mg} \mathrm{l}^{-1}$ and $27,100 \mathrm{mg} \mathrm{l}^{-1}$, respectively. TCOD and SCOD were $50,600 \mathrm{mg} \mathrm{l}^{-1}$ and $3,700 \mathrm{mg} \mathrm{l}^{-1}$, respectively. The ratio of SCOD/TCOD was about $7 \%$. 
Table 6 Characteristics of feed PS for the semi-continuous reactor.

\begin{tabular}{|l|l|l|}
\hline Parameter & Mean & Stdev \\
\hline $\mathrm{pH}$ & 6 & 0.13 \\
\hline TSS $\left(\mathrm{mg} \mathrm{l}^{-1}\right)$ & 34,000 & 7,690 \\
\hline VSS $\left(\mathrm{mg} \mathrm{l}^{-1}\right)$ & 27,100 & 6,230 \\
\hline TCOD $\left(\mathrm{mg} \mathrm{l}^{-1}\right)$ & 50,700 & 3,670 \\
\hline $\mathrm{SCOD}\left(\mathrm{mg} \mathrm{l}^{-1}\right)$ & 3,700 & 327 \\
\hline $\mathrm{NH}_{3}-\mathrm{N}\left(\mathrm{mg} \mathrm{l}^{-1}\right)$ & 51 & 14 \\
\hline Alkalinity (mg l-1) & 1,000 & 190 \\
\hline VFAs (mg COD l-1) & 1,400 & 157 \\
\hline VFAs/VSS (mg COD g-1 VSS feed) & 54 & 10 \\
\hline TBOD $\left(\mathrm{mg} \mathrm{l}^{-1}\right)$ & 19,700 & 4,740 \\
\hline
\end{tabular}

The data in this table is the average and standard deviation of six samples

\subsubsection{VFAs and SCOD production for $\mathrm{pH} 4.5$}

For the semi-continuous experiments, six liquid samples were collected for each run after reaching a steady state, i.e., after 3 times HRT, for example, for HRT of 3 days, the liquid samples were collected after 9 days of starting the experiment. Figure 10 and Figure 11 show the VFAs production and SCOD production trends, respectively, for $\mathrm{pH} 4.5$ and different HRTs of 1 day, 2 days, and 3 days for the six samples.

As shown in Figure 10, the VFAs concentrations for HRT of 1 day were higher than those for 2 and three days. Furthermore, there was no significant difference between the VFAs at HRT of 2 days and HRT of 3 days. As depicted in Figure 10 and Figure 11, for HRT of 1 day, the average VFAs production was $(3587 \pm 276) \mathrm{COD}^{-1}$ which was corresponding to average SCOD of $(7173 \pm 236) \mathrm{mg} \mathrm{l}^{-1}$. For HRT of 2 days, the average VFAs production was $(2769 \pm 290) \mathrm{mg} \mathrm{COD} \mathrm{l}^{-1}$ which was corresponding to average SCOD of (9255 \pm 638$)$ 
$\mathrm{mg} \mathrm{l}^{-1}$. For HRT of 3 days, the average VFAs production was $(2534 \pm 241) \mathrm{mg} \mathrm{COD} \mathrm{l}^{-1}$ which was corresponding average SCOD of $(9103 \pm 811) \mathrm{mg} \mathrm{l}^{-1}$.

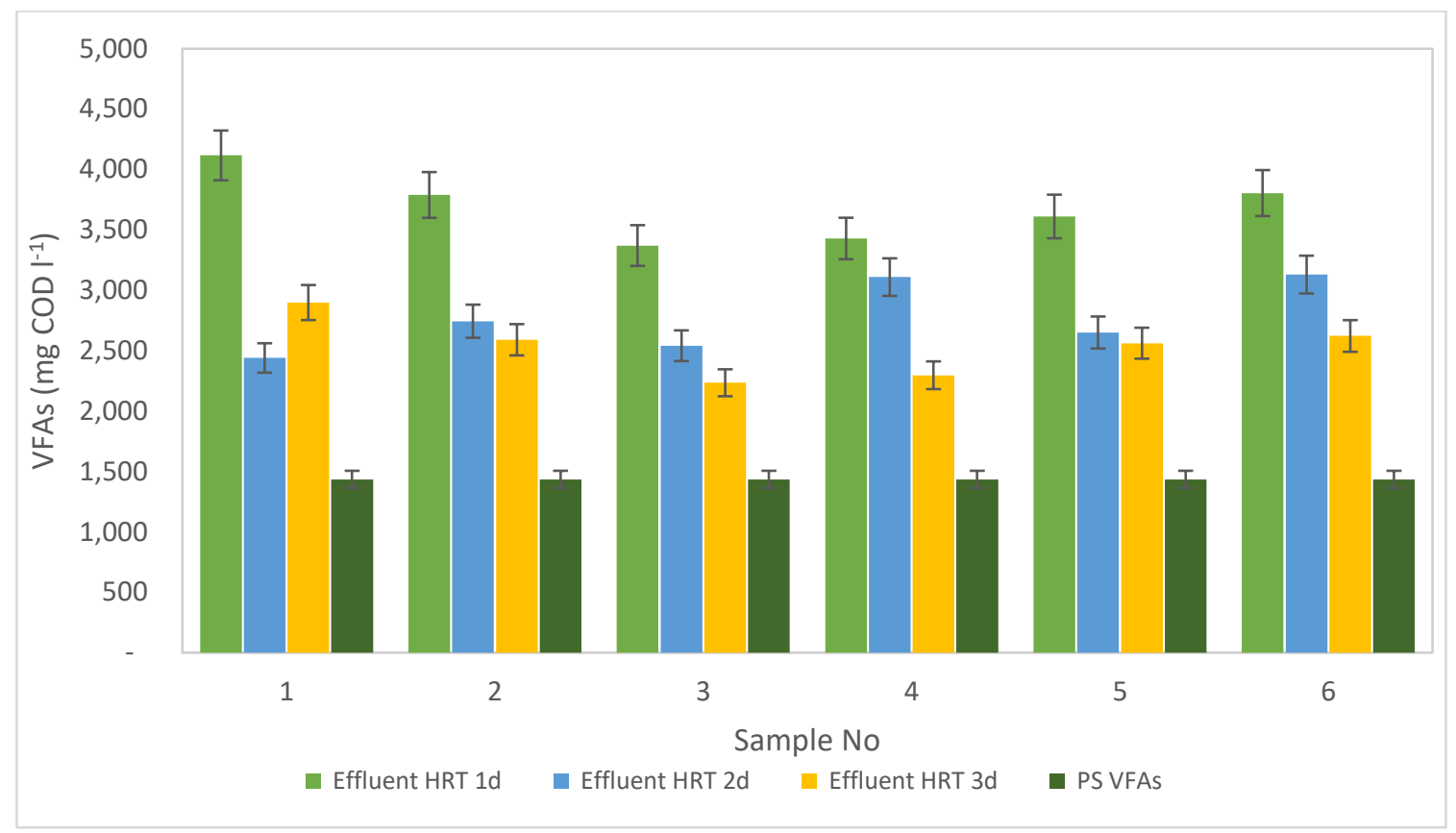

Figure 10 VFAs production data for $\mathrm{pH} 4.5$ and different HRTs

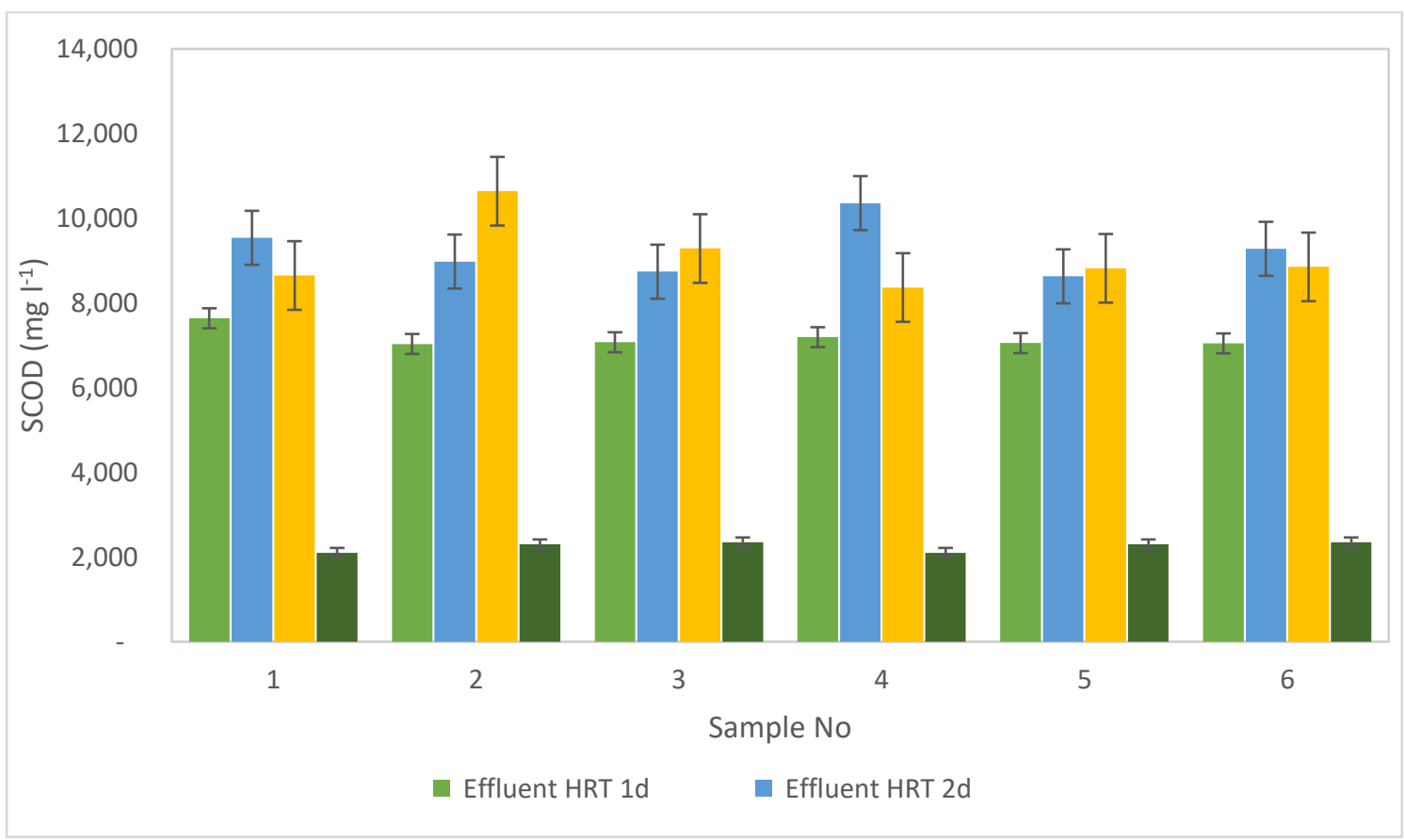

Figure 11 SCOD data for $\mathrm{pH} 4.5$ and different HRTs 


\subsubsection{VFAs and SCOD production for $\mathrm{pH} 5.5$}

Figure 12 and Figure 13 describes the VFAs production and SCOD production trend respectively for $\mathrm{pH} 5.5$ and HRT 1day, 2 days and 3 days for six samples for the semicontinuous experiment of primary sludge fermentation. As demonstrated in Figure 12 and Figure 13 , for HRT of 1 day, the average VFAs production for $\mathrm{pH} 5.5$ was $(3400 \pm 297)$ $\mathrm{COD} \mathrm{l}^{-1}$ which was corresponding to average SCOD of $(6238 \pm 551) \mathrm{mg} \mathrm{l}^{-1}$. For HRT of 2

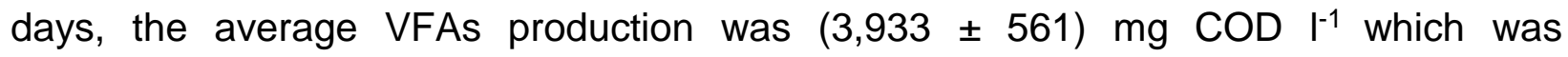
corresponding to average SCOD of $(9,188 \pm 876) \mathrm{mg} \mathrm{l}^{-1}$. For HRT of 3 days, the average VFAs production was $(3,197 \pm 373) \mathrm{mg} \mathrm{COD} \mathrm{l}^{-1}$ which was corresponding average SCOD of $(10,157 \pm 448) \mathrm{mg} \mathrm{l}^{-1}$.

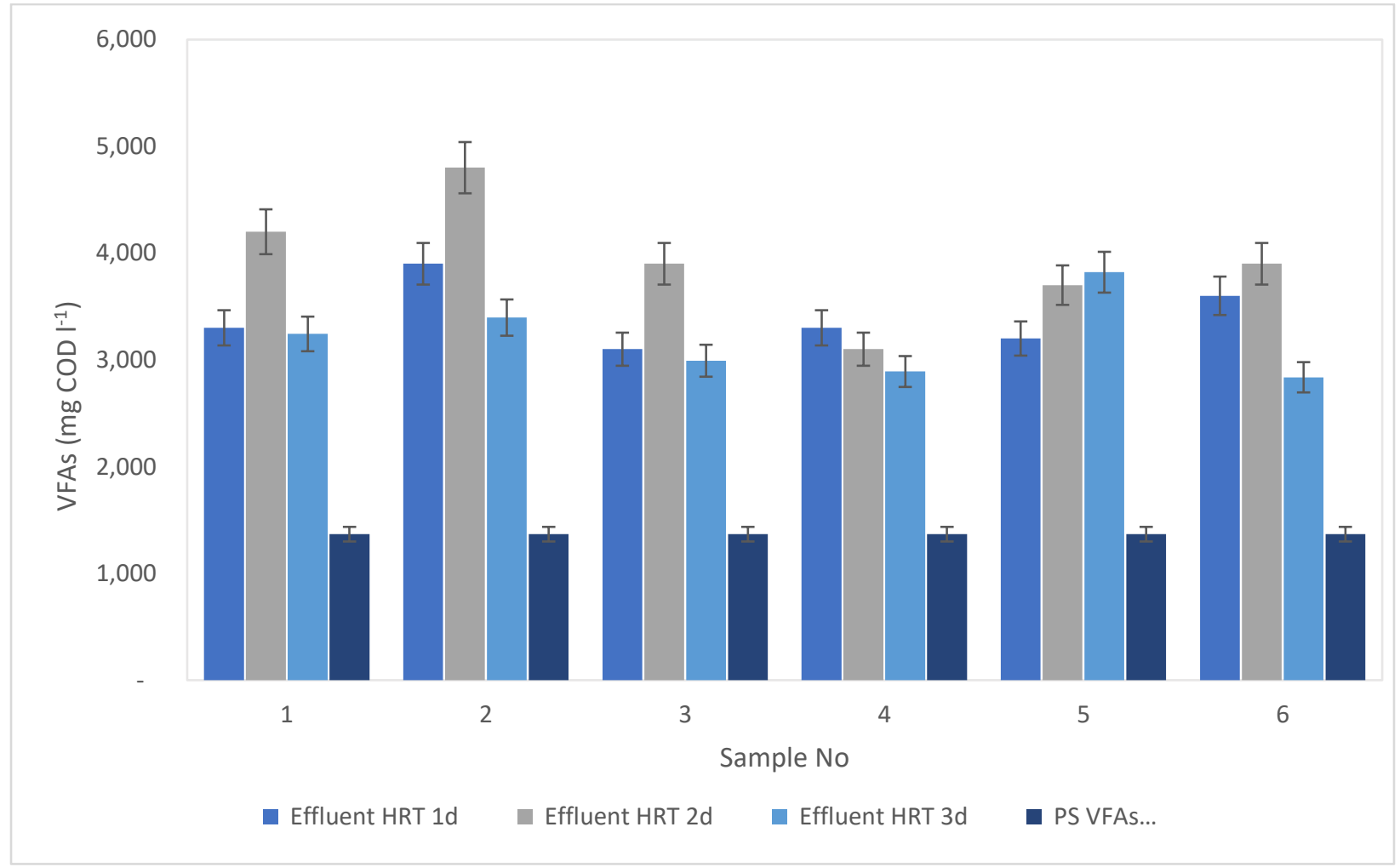

Figure 12 VFAs data for $\mathrm{pH} 5.5$ and different HRTs 


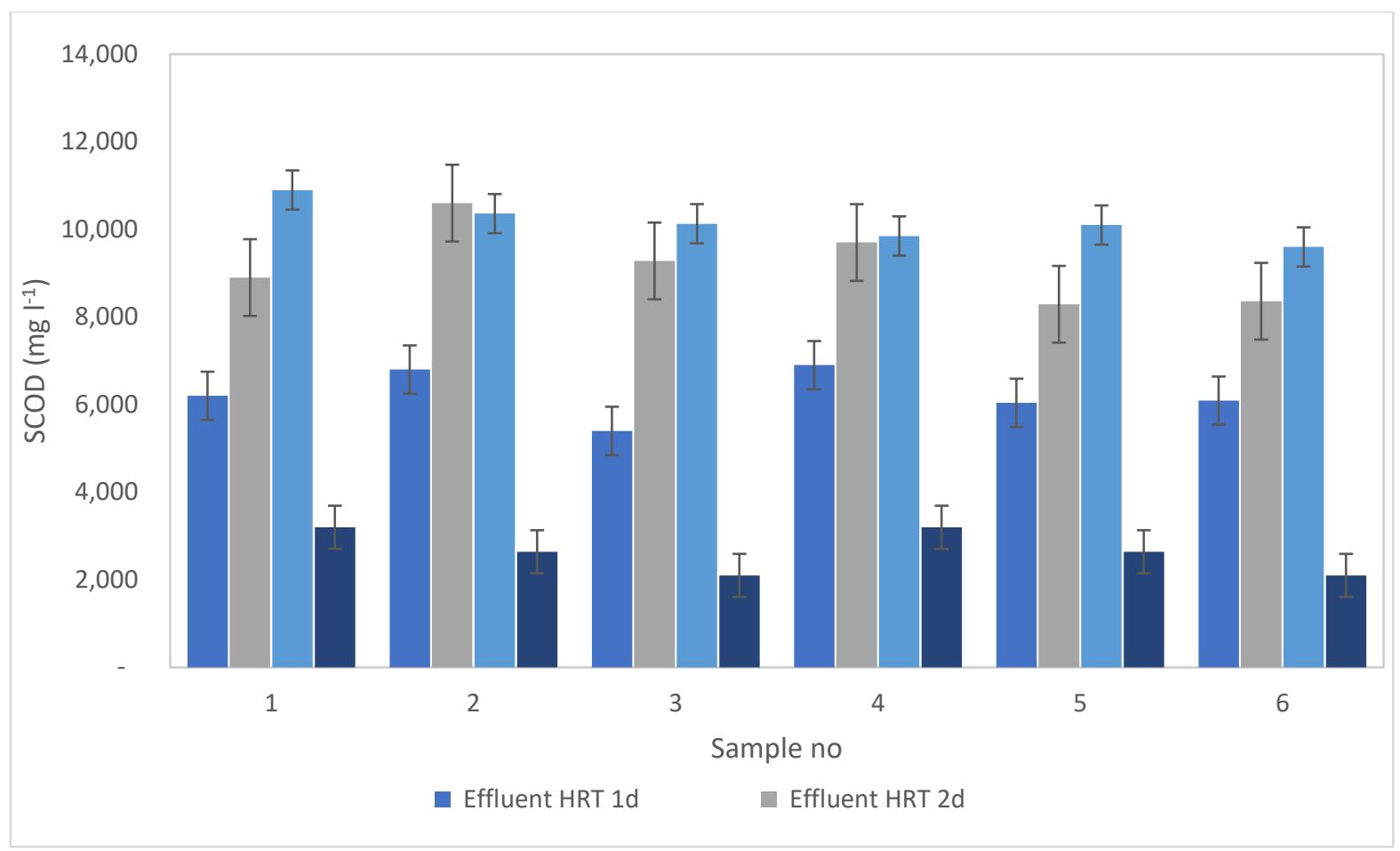

Figure 13 SCOD data for $\mathrm{pH} 5.5$ and different HRTs

\subsubsection{VFAs and SCOD production for $\mathrm{pH} 6.5$}

Figure 14 and Figure 15 describes the VFAs production and SCOD production trend respectively for $\mathrm{pH} 6.5$ and HRT 1 day, 2 days and 3 days for six samples. At the mesophilic temperature and $\mathrm{pH}$ 6.5, as described in Figure 14 and Figure 15, for HRT of 1 day, the average VFAs production was $(2,469 \pm 451) \mathrm{COD}^{-1}$ which was corresponding to average SCOD of $(7,255 \pm 101) \mathrm{mg} \mathrm{l}^{-1}$.

For HRT of 2 days, the average VFAs production was $(4,530 \pm 860) \mathrm{mg} \mathrm{COD}^{-1}$ which was corresponding to average SCOD of $(14,377 \pm 205) \mathrm{mg} \mathrm{l}^{-1}$. For HRT of 3 days, the average VFAs production was $(6,549 \pm 528) \mathrm{mg} \mathrm{COD} \mathrm{l}^{-1}$ which was corresponding average SCOD of $(14,554 \pm 414) \mathrm{mg} \mathrm{l}^{-1}$. 


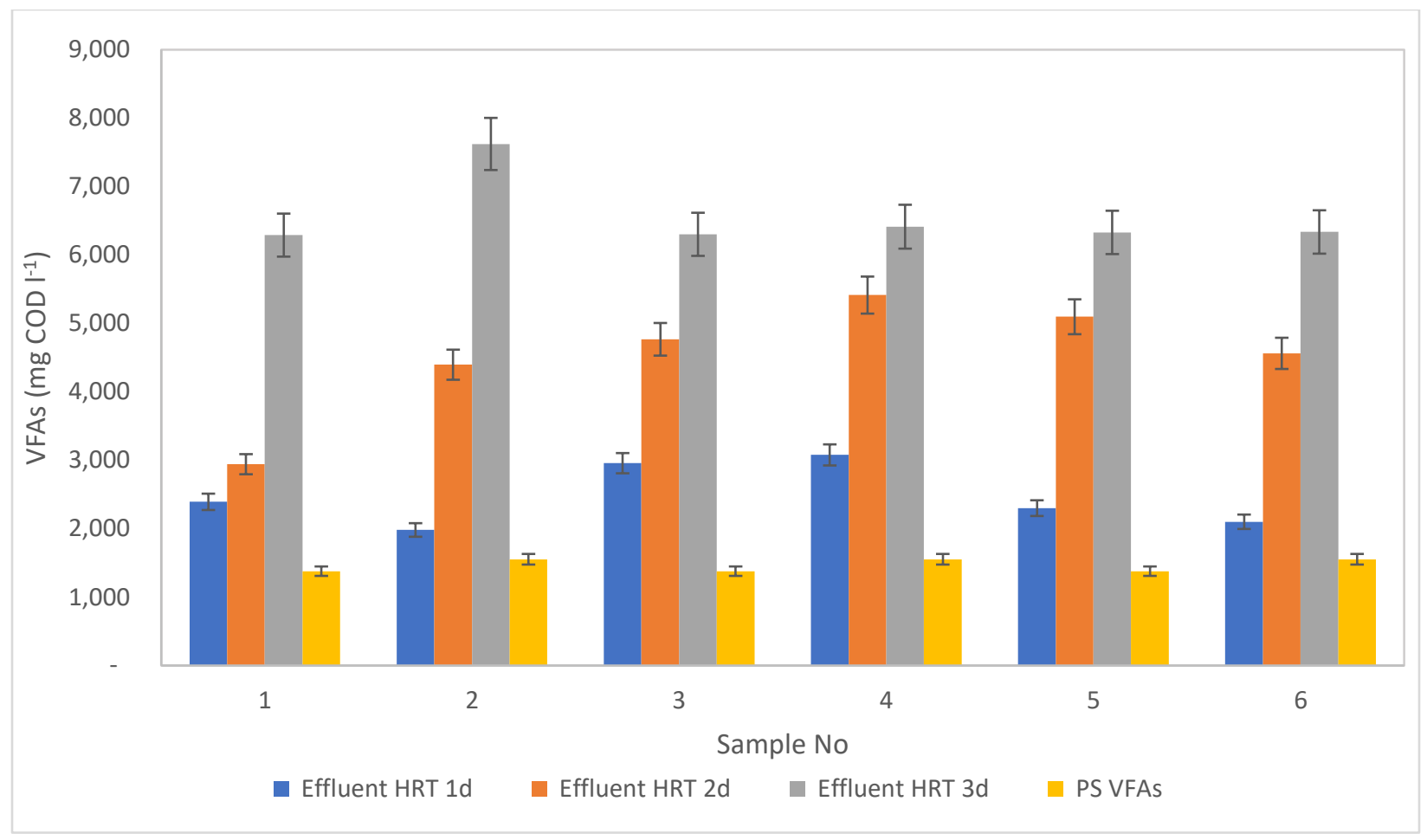

Figure 14 VFAs data for $\mathrm{pH} 6.5$ and different HRTs

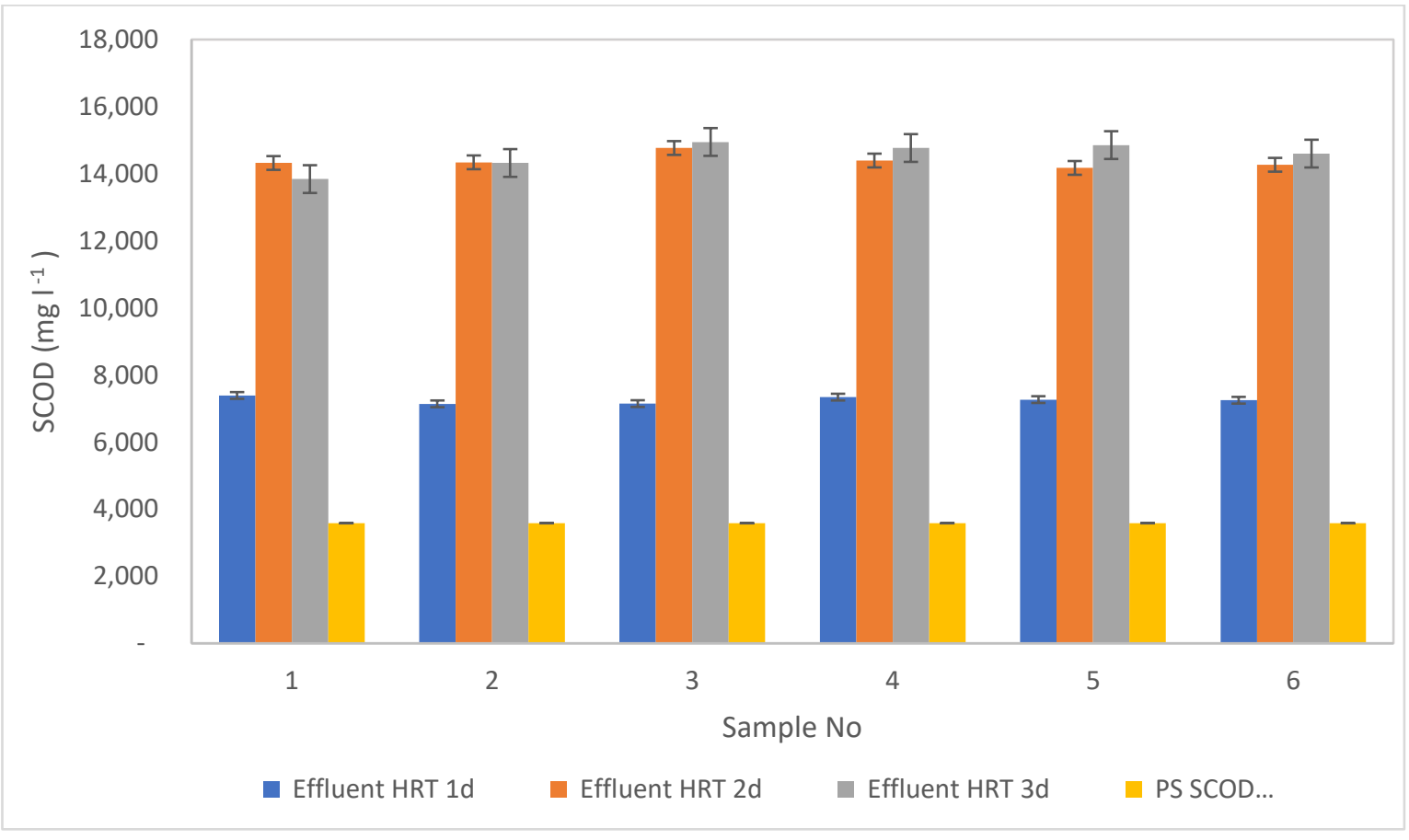

Figure 15 SCOD data for $p H 6.5$ and different HRTs 
5.2.5 VFAs and SCOD production for $\mathrm{pH} 4.5,5.5,6.5$ and different HRTs

PS was fermented under the designed condition to produce VFAs and optimize the design conditions to maximize the VFAs production. Figure 16 describes the comparison of VFAs production on $\mathrm{pH} 4.5,5.5,6.5$ based on average VFAs data for the semi-continuous experiment of PS anaerobic fermentation. Each pH was fixed over three HRTs 1 day, 2 days, and 3 days. $\mathrm{pH} 5.5$ shows a gradual increase of VFAs production from HRT 1 day until 2 days but it dropped in HRT of 3 days. Whereas $\mathrm{pH} 6.5$ depicts a significant increase in the production of VFAs from HRT 1 day to 3 days. $\mathrm{pH} 4.5$ can be considered as an extremely acidic condition which acts as the inhibitory situation for acidogens for VFAs production as the graph does not shows any increment in VFAs accumulation rather shows a decreasing trend.

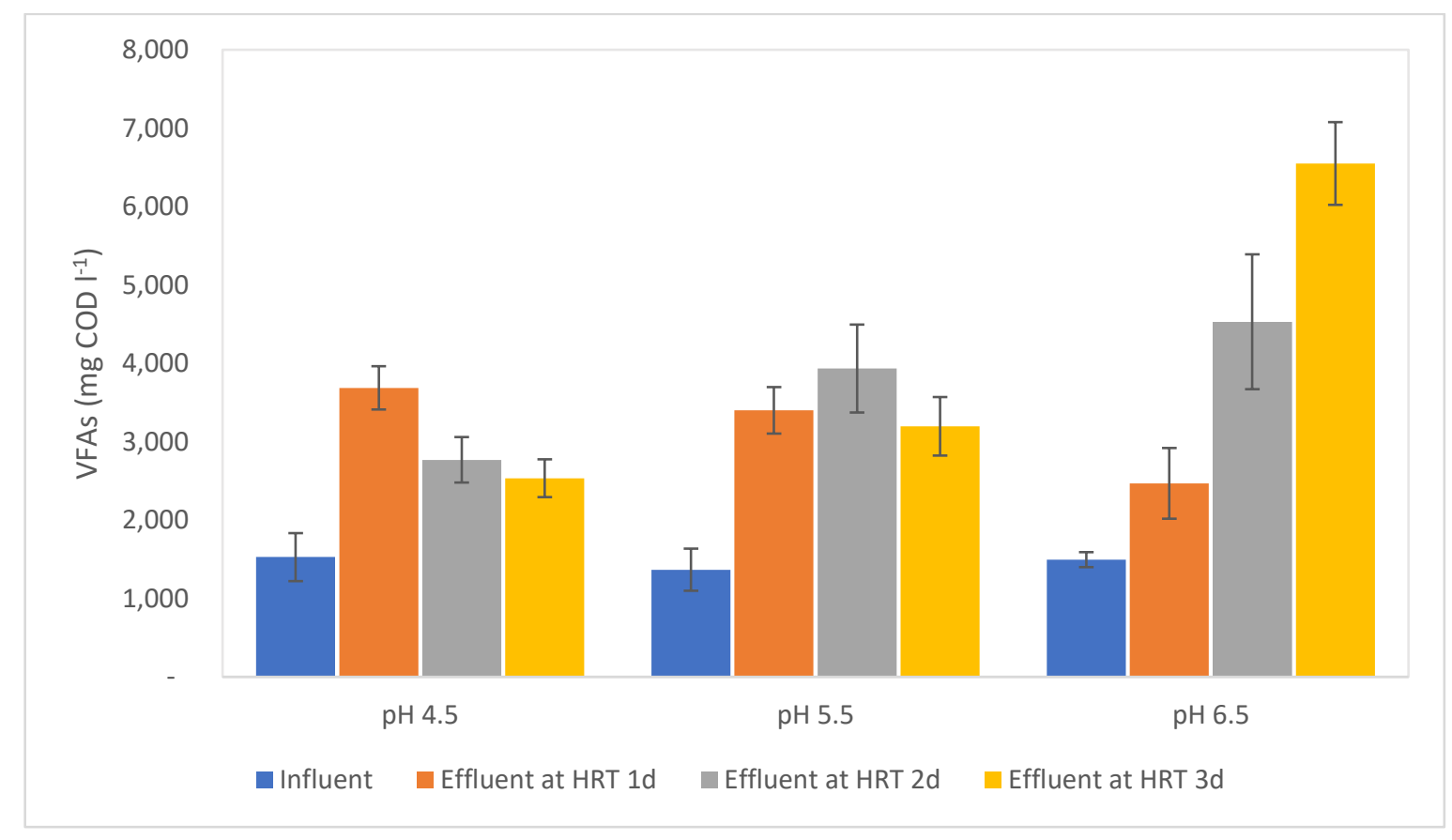

Figure 16 VFAs data for different HRTs and pHs for semi-continuous experiment 
Figure 17 shows the solubilization trend of $\mathrm{PCOD}$ to SCOD for semi-continuous studies. The graph shows a gradual increase in SCOD with increasing HRT from 1 day to 3 days for $\mathrm{pH} 5.5$ and 6.5. However, data for $\mathrm{pH} 4.5$ which is more acidic condition does not comply this trend. For pH 4.5, SCOD increases until HRT 2 day but decreases with the increase of HRT to 3 days. pH 6.5 and HRT 3 days shows maximum SCOD $(14,554 \pm$ $414 \mathrm{mg} \mathrm{COD}^{-1}$ ) production which in agreement with the VFAs data. SCOD data also shows an increasing trend over an increment of HRTs for all the $\mathrm{pH}$ values.

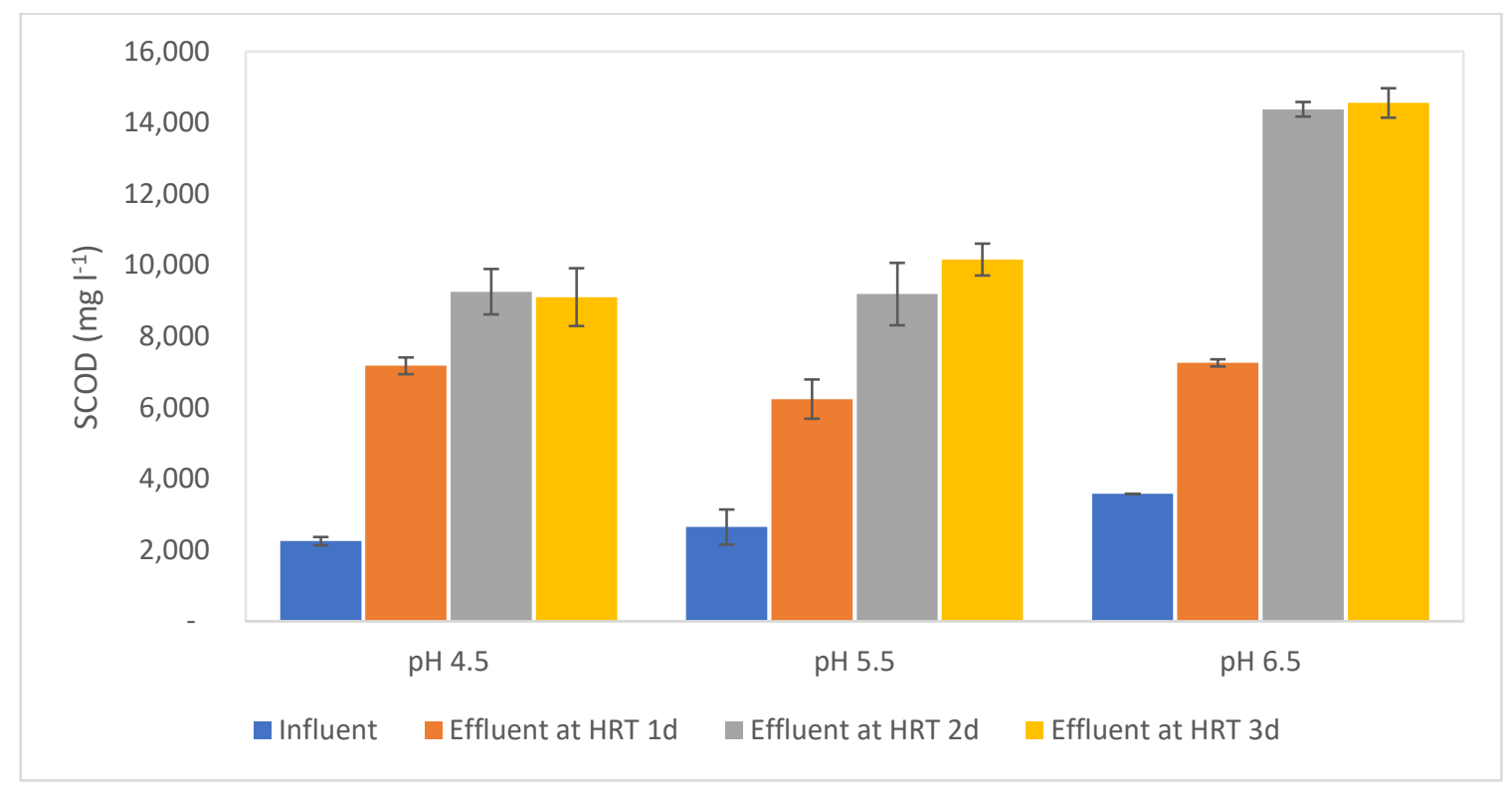

Figure 17 SCOD data for different HRTs and pHs for semi-continuous experiment

\subsubsection{The degree of solubilization for $\mathrm{pH}$ 4.5,5.5,6.5 and different HRTs}

The degree of solubilization is a measure to what extent the particulate or solid fraction of PS is solubilized, i.e., converted to SCOD during the fermentation process. The degree of solubilization for the fermenter during the semi-continuous experiment was measured using equation (14). 
As shown in Figure 18, the maximum degree of solubilization of $25 \%$ along with corresponding SCOD of $14,554 \mathrm{mg} \mathrm{l}^{-1}$ and VFAs of $5,549 \mathrm{mg} \mathrm{COD}^{-1}$ were achieved at pH 6.5 and HRT of 3 days. Data for pH 6.5 and HRT of 2 days also shows a degree of solubilization $25 \%$ with a lesser value of SCOD $14,377 \mathrm{mg} \mathrm{l}^{-1}$ and VFAs $4,782 \mathrm{mg} \mathrm{COD} \mathrm{I}^{-}$ ${ }^{1}$ which almost equal to those of HRT 3 days. The degree of solubilization for HRT of 1 day was only $8 \%$. For the of 5.5 , the degree of solubilization increased with increasing the HRT, it was $7 \%, 15 \%$, and $20 \%$ for HRT of 1,2 , and 3 days, respectively.

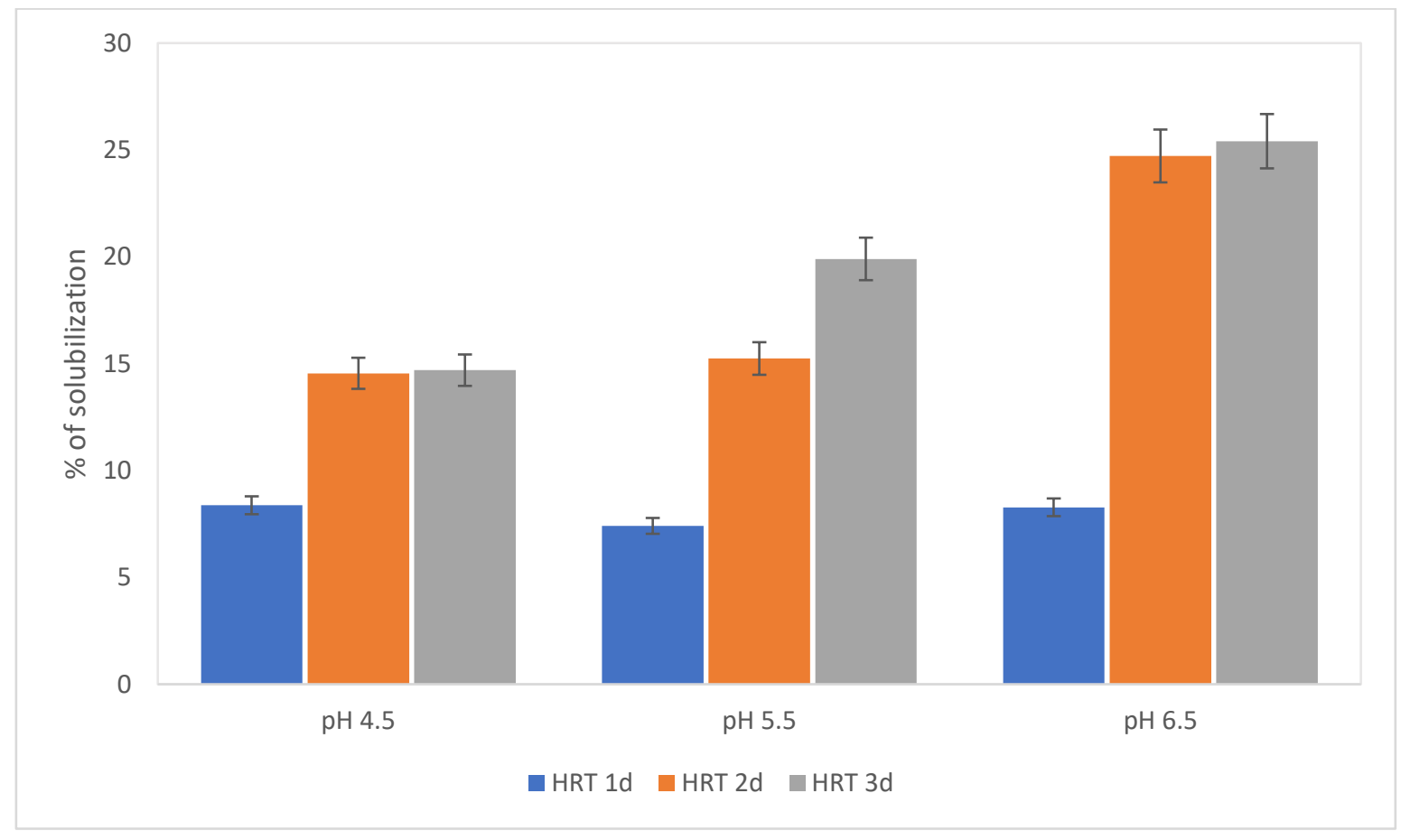

Figure 18 Degree of solubilization different HRTs and pHs for semi-continuous experiment

For $\mathrm{pH} 4.5$, the degree of solubilization was $8 \%, 15 \%$, and $15 \%$ for HRT of 1,2 , and 3 days, respectively. The above data emphasis that the degree of solubilization for HRT 2 days and 3 days does not have significant difference. 


\subsubsection{VFAs yield, SCOD yield, VFAs/SCOD ratio}

VFAs yield and VFAs/SCOD ratio is the measure of accomplishment of acid fermentation or acidification, representing the amount of VFAs converted from solubilized matter, i.e., SCOD. VFAs yield as $\mathrm{mg} \mathrm{COD} \mathrm{g}^{-1} \mathrm{VSS}_{\text {feed }}$ and VFAs/SCOD ratio (\%) are shown in Figure 19 and Figure 20, respectively. The semi-continuous study of PS fermentation indicates that for $\mathrm{pH} 4.5$, VFAs yield decreases gradually as the HRT increases from 1day to 3 days: VFAs yields of 150,94 , and $86 \mathrm{mg} \mathrm{COD} \mathrm{g}^{-1}$ VSS feed were observed at HRT of 1, 2, and 3 days, respectively. However, for $\mathrm{pH}$ 5.5, VFAs yield increases from $150 \mathrm{mg}$ COD $\mathrm{g}^{-1} \mathrm{VSS}_{\text {feed }}$ at HRT 1 day to192 $\mathrm{mg} \mathrm{COD} \mathrm{g}^{-1} \mathrm{VSS}_{\text {feed }}$ at HRT of 2 days and decreased to $130 \mathrm{mg} \mathrm{COD} \mathrm{g}^{-1} \mathrm{VSS}_{\text {feed }}$ as HRT increases to 3 days.

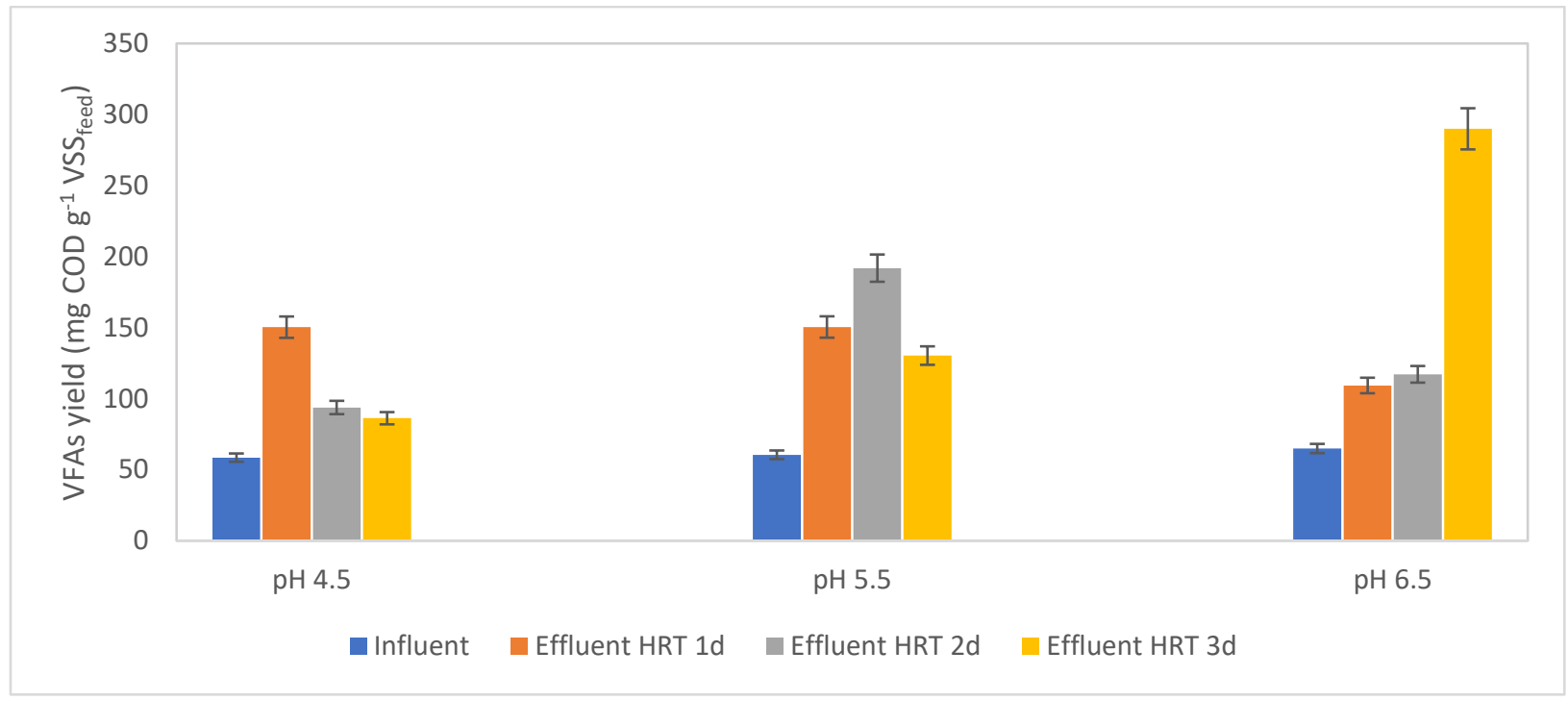

Figure 19 VFAs yield data for different HRTs and $\mathrm{pHs}$ for semi-continuous experiment

For $\mathrm{pH}$ 6.5, VFAs yield shows opposite trend to that of $\mathrm{pH} 4.5$. For $\mathrm{pH} 6.5$, VFAs yield clearly shows a steady increasing pattern from 1 day to 3 days: $109 \mathrm{mg} \mathrm{COD} \mathrm{g}^{-1}$ VSS feed $_{\text {f }}$

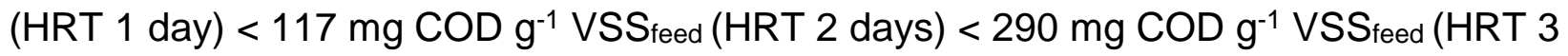
days). The highest value of VFAs yield of $290 \mathrm{mg} \mathrm{COD} \mathrm{g}^{-1} \mathrm{VSS}_{\text {feed }}$ was achieved at $\mathrm{pH}$ 
6.5 and HRT 3 days. The probable reason for decreasing VFAs yield from 1 day to 3 days for $\mathrm{pH}$ values of 4.5 and 5.5 could be due to the consumption of the VFAs to produce alcohol i.e., ethanol. The optimum $\mathrm{pH}$ for ethanol production is $\mathrm{pH}$ 4.5-5.0.

Figure 20 shows the VFAs/SCOD ratios for different pHs and HRTs. As shown in the figure, the VFAs/SCOD ratio showed gradual decreasing pattern for $\mathrm{pH} 5.5$ and 6.5 with an increase of HRT from 1 day until 3 days. VFAs/SCOD ratios for $\mathrm{pH} 5.5$ of $51 \%, 30 \%$, and $28 \%$, were observed for HRTs of 1,2 , and 3 days, respectively. For $\mathrm{pH} 6.5$, VFAs/SCOD ratios of $55 \%, 43 \%$, and $31 \%$ were observed for HRTs of 1,2 , and 3 days, respectively. However, VFAs/SCOD ratio at $\mathrm{pH} 6.5$ shows a slight decrease from HRT 1 day $(32 \%)$ to 2 days (34\%) then an increase with the increase of HRT from 2 days until 3 days $(45 \%)$.

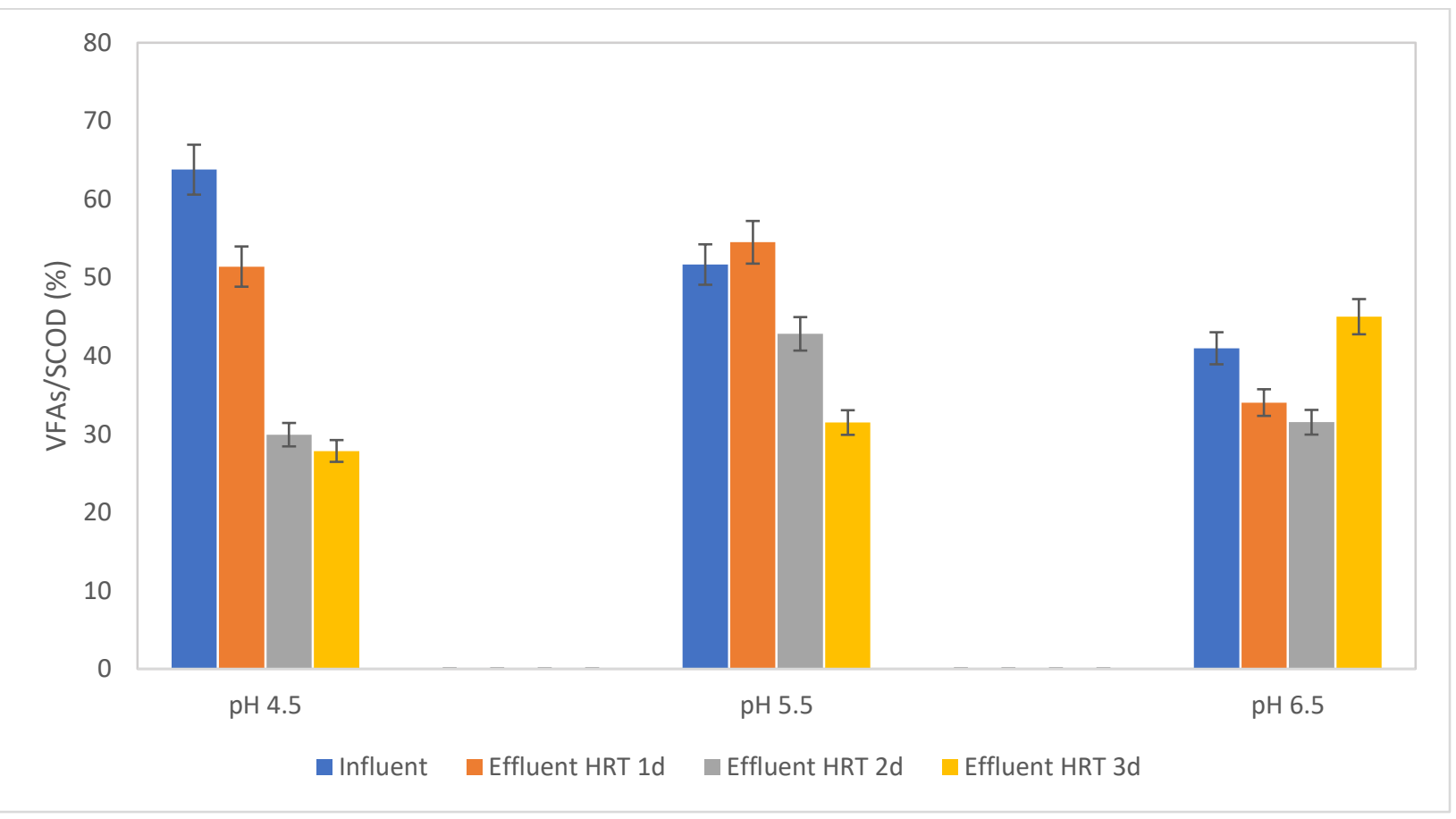

Figure $20 \mathrm{VFAs} / \mathrm{SCOD}$ ratio for different HRTs and pHs for semi-continuous experiment 


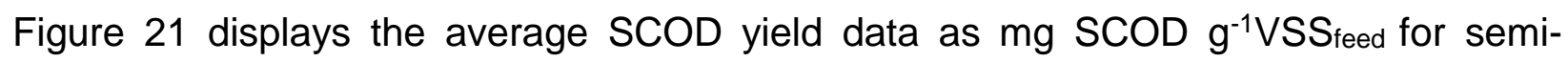
continuous fermentation. SCOD yield data demonstrates an increasing trend for all the $\mathrm{pHs}$ values when HRT increased from 1 day to 3 days. SCOD yield data for $\mathrm{pH} 4.5$ ranged from $292 \mathrm{mg} \mathrm{SCOD} \mathrm{g}^{-1} \mathrm{VSS}_{\text {feed }}$ (at HRT 1 day) to $310 \mathrm{mg} \mathrm{SCOD} \mathrm{g}^{-1} \mathrm{VSS}_{\text {feed }}$ (at HRT 3 days).

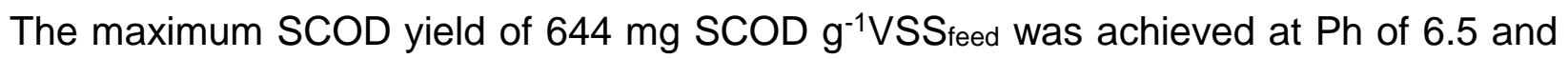
HRT of 3 days. For pH 6.5 the SCOD yield data for HRT 2 days and 3 days does not have significant difference.

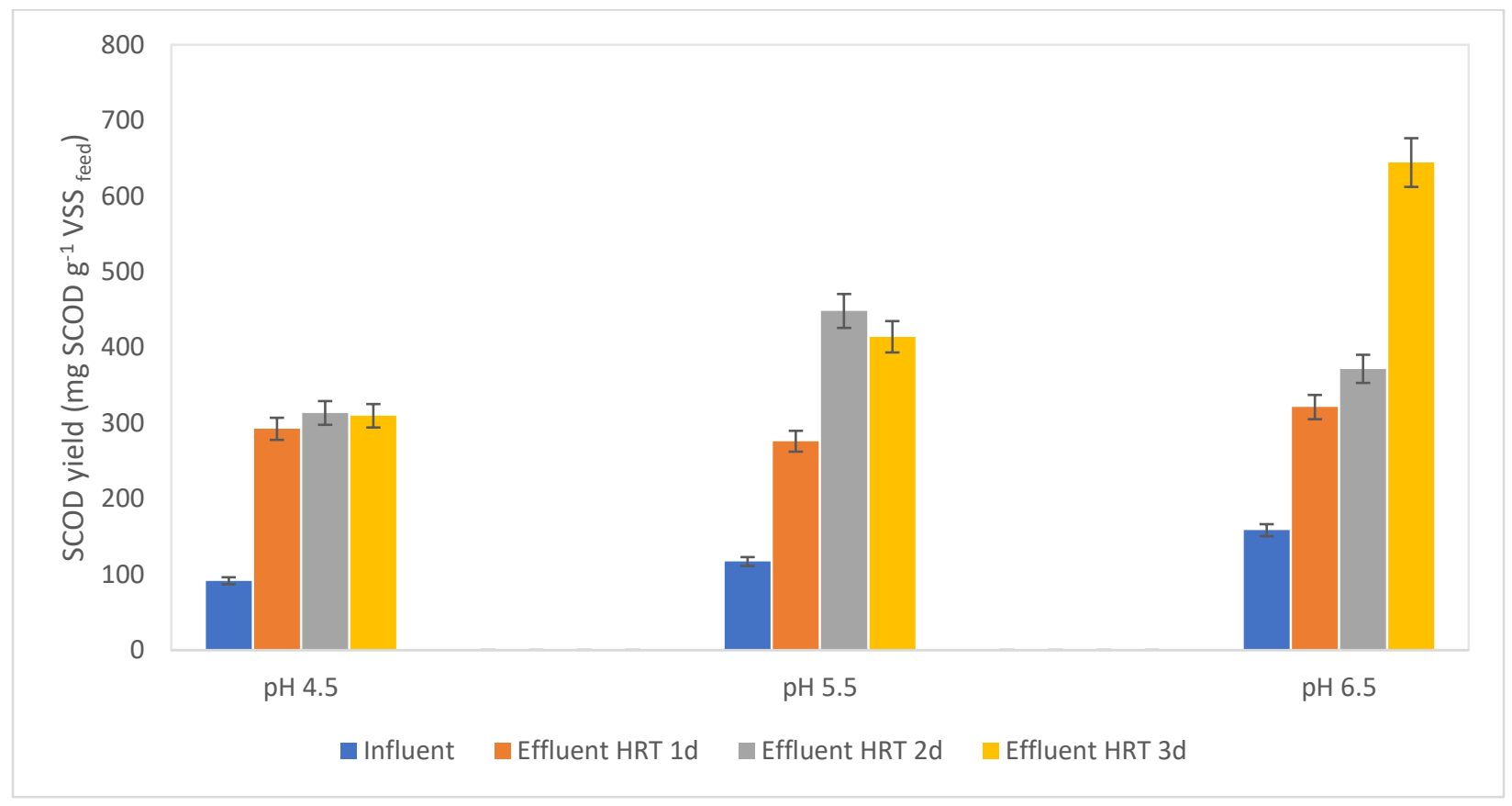

Figure 21 SCOD yield data for different HRTs and pHs for semi-continuous experiment

\subsubsection{Discussion on Semi-continuous experiment results}

$\mathrm{pH}$ of a fermenter has a direct influence of VFAs production as the growth rate microbes and microbial activities are significantly impacted by the changes of $\mathrm{pH}$ conditions [53]. The semi-continuous study cases higher VFAs production as the $\mathrm{pH}$ increases and was higher for $\mathrm{pH} 5.5$ and 6.5 for HRT 2 days and 3 days respectively. The hydrolytic enzymes, as well as the hydrolysis and disintegration, can be affected by various $\mathrm{pH}$ 
conditions [35]. Microbial activities and hydrolysis process are also facilitated by multiple non-biological processes, i.e., physiochemical methods such as acidic, alkaline, steam explosion, ultrasonic or microwave, etc. [46]. By comparing both the batch and semicontinuous experiment results of this experiments, it can be decided that alkaline $\mathrm{pH}$ conditions could be a considerable alternative as compared to acidic $\mathrm{pH}$ conditions for higher hydrolysis and disintegration.

Both SRT and HRT controls the efficiency of VFAs production from anaerobic fermentation process [54]. Lower HRT can lead to a risk of biomass washout for semicontinuous experiment resulting in a low VFA yield. Higher SRT can cause the production of methane. However, shorter SRT compared to the optimum value causes more VFAs accumulation, increased alkalinity and methanogens washouts [26]. HRT should be determined to bear in mind the operational temperature and the content of the organic substrate of the specific fermenter.

As per statistical one-way ANOVA analysis VFAs yield shows significant difference as demonstrates $\mathrm{p}$ value $\leq 0.05$ for $\mathrm{pH} 4.5$ to 5.5 with $\mathrm{p}$ value 0.01 (appendix $\mathrm{D}$ ), $\mathrm{pH} 4.5-6.5$ with $p$ value 0.003 (appendix D). But pH $5.5-6.5$ does not show any significant difference with $p$ value 0.66 (appendix D). SCOD yield follows the same pattern as VFAs yield. SCOD yield shows significant difference as displays $p$ value $\leq 0.05$ for $\mathrm{pH} 4.5$ to 5.5 with $\mathrm{p}$ value 0.000 (appendix D), $\mathrm{pH} 4.5-6.5$ with $\mathrm{p}$ value 0.000 (appendix D). But pH $5.5-6.5$ does not show any significant difference with $p$ value 0.119 (appendix D).

For this experiment acidogenic fermentation of semi-continuous study under mesophilic conditions shows highest VFAs production ( $\left.6549 \pm 528 \mathrm{mg} \mathrm{COD} \mathrm{I}^{-1}\right)$, VFAs yield (290 mg

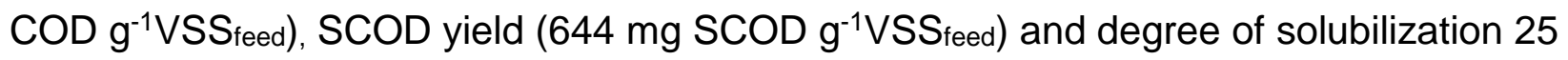


\% for $\mathrm{pH} 6.5$ with HRT 3 days. So, for semi-continuous acidogenic fermentation $\mathrm{pH}, 6.5$ and HRT 3 days was recommended $\mathrm{pH}$ under mesophilic condition. 


\section{Conclusions}

\subsection{Anaerobic fermentation of PS batch study}

Based on the batch fermentation of PS at different pHs and different HRTs, the following points can be concluded:

- The maximum VFAs yield was achieved at HRT of 3 days, However, there were no significant differences when the $\mathrm{pH}$ changed from 6.5 to 10.0 , i.e., there was no significant effect of the $\mathrm{pH}$ in the range of 6.5 to 10 on the VFAs yields.

- The HRT has a significant effect on the VFAs yield for all $\mathrm{pH}$ values except $\mathrm{pH} 11.0$.

- The optimum conditions for SCOD yield and the degree of solubilization were HRT of 3 days and $\mathrm{pH} 10.0$.

- The VFAs/SCOD ratio was higher for acidic $\mathrm{pH}$ compared to alkaline $\mathrm{pH}$.

- The maximum VFAs yield $230 \mathrm{mg} \mathrm{COD} \mathrm{g}^{-1} \mathrm{VSS}_{\text {feed }}$ was observed at $\mathrm{pH} 10.0$ and HRT of 3 days; corresponding to the maximum SCOD concentration of $10,700 \mathrm{mg} \mathrm{l}^{-1}$,

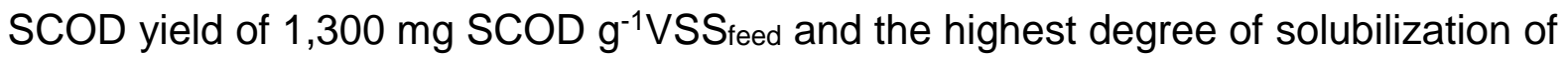
$48 \%$.

For the batch study, the $\mathrm{pH}$ range for maximum VFAs yield is $\mathrm{pH} 6.5-10.0$ and HRT of 3 days.

\subsection{Anaerobic fermentation of PS semi-continuous study}

Based on the semi-continuous flow fermentation of PS at different $\mathrm{pHs}$ and different HRTs, the following points can be concluded:

- VFAs production increases with an increase in HRT. 
- Maximum VFAs production \& yield, SCOD yield observed at $\mathrm{pH} 6.5$, HRT of 3 days $\left(35^{\circ} \mathrm{C}\right)$.

- The highest VFAs concentration 6,549 $\mathrm{mg} \mathrm{COD}^{-1}$, SCOD concentration $14,600 \mathrm{mg}$ SCOD ${ }^{-1}$ and degree of solubilization $25 \%$ were achieved at $\mathrm{pH} 6.5$ and HRT of 3 days.

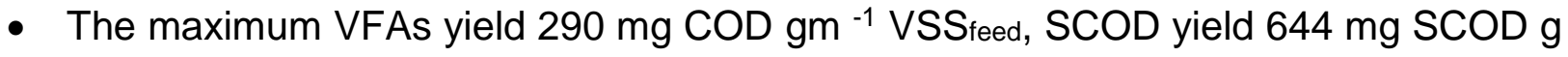
${ }^{-1} \mathrm{VSS}_{\text {feed }}$ were achieved as well for $\mathrm{pH} 6.5$ and HRT of 3 days.

- The high SCOD concentration of 9,000 to $14,500 \mathrm{mg} \mathrm{l}^{-1}$ was achieved at SRT of 3 days for the three pHs.

For the semi-continuous study, the maximum amount of VFAs production observed at $\mathrm{pH}$ 6.5 and HRT of 3 days. 


\section{Recommendations and Future Research}

The results of this study reveal that the PS has excellent potential to produce VFAs by dark fermentation. However, the highest VFAs production was achieved at high HRT of 3 days. From a practical point of view, this HRT is high, and thus it is required to try to push this HRT to one day by combining the dark fermentation with another technology that has low footprint such thermal hydrolysis pre-treatment of combining the dark fermentation with microbial electrochemical cells. Another technique to reduce the HRT is doubling the SRT from HRT using solid-liquid separation method and recirculate the solids back to the fermenter. It is also recommended to investigate VFAs production through the semi-continuous experiment at alkaline $\mathrm{pH}(8-11)$ conditions as well as the fermentation process at different $\mathrm{pH}$ at the thermophilic temperature condition. 


\section{Appendices}

\section{A. Batch experiments}

Table 7 Data for batch test of PS anaerobic fermentation $\mathrm{pH} 4.5$ at $35^{\circ} \mathrm{C}$

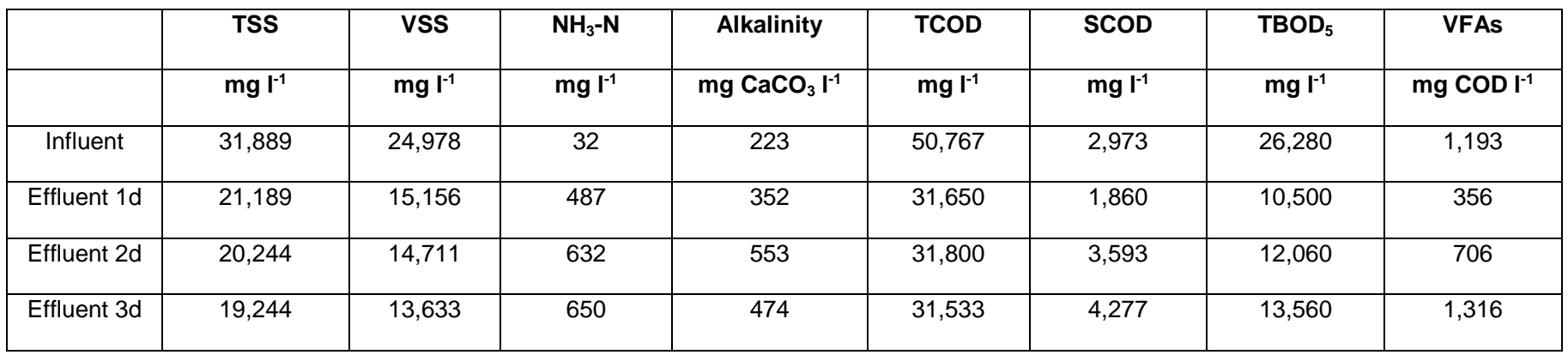

Table 8 Data or batch test of PS anaerobic fermentation pH 5.5 at $35^{\circ} \mathrm{C}$.

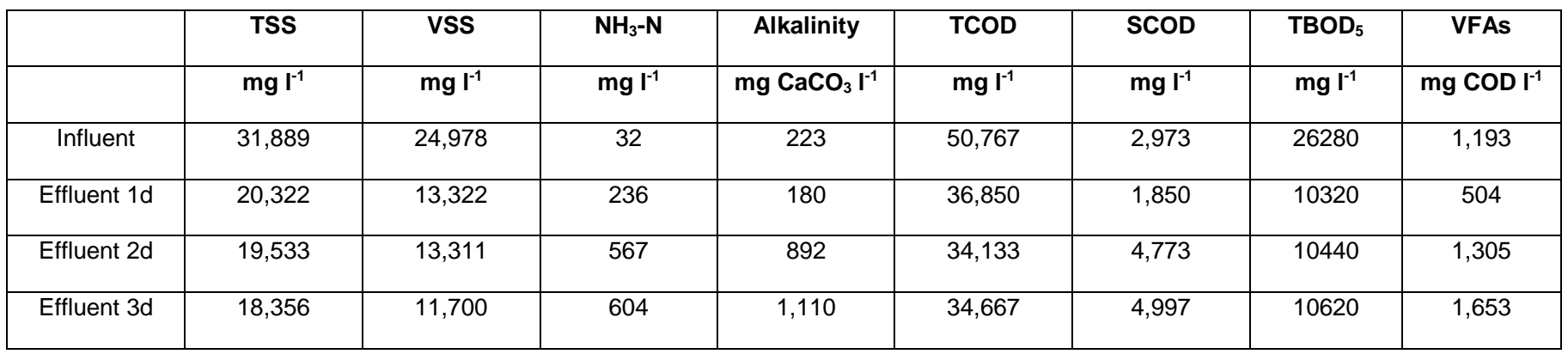

Table 9 Data for batch test of PS anaerobic fermentation pH 6.5 at $35^{\circ} \mathrm{C}$.

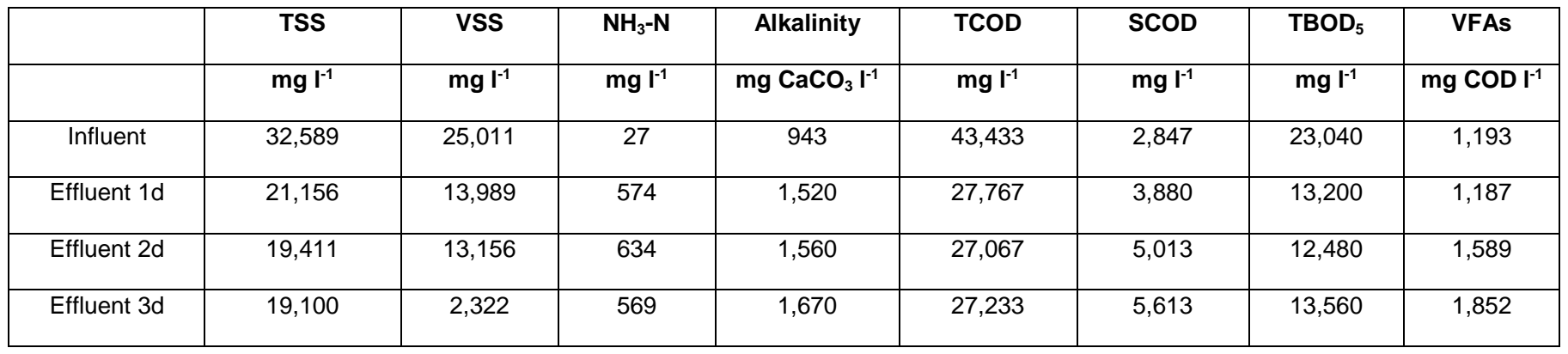


Table 10 Data for batch test of PS anaerobic fermentation $\mathrm{pH} 8.0$ at $35^{\circ} \mathrm{C}$.

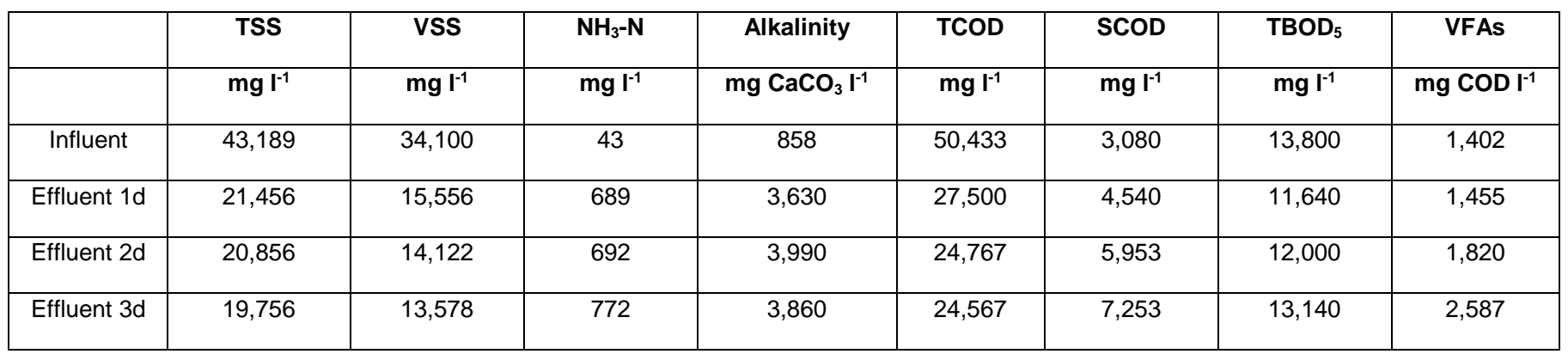

Table 11 Data for batch test of PS anaerobic fermentation $\mathrm{pH} 9.0$ at $35{ }^{\circ} \mathrm{C}$.

\begin{tabular}{|c|c|c|c|c|c|c|c|c|}
\hline & TSS & VSS & $\mathbf{N H}_{3}-\mathbf{N}$ & Alkalinity & TCOD & SCOD & TBOD & VFAs \\
\hline & $\mathbf{m g ~ l}^{-1}$ & $\mathbf{m g ~ l}^{-1}$ & $\mathbf{m g ~ l}^{-1}$ & $\mathbf{m g ~ C a C O}_{3} \mathbf{l}^{-1}$ & $\mathbf{m g ~ l}^{-1}$ & $\mathbf{m g ~ l}^{-1}$ & $\mathbf{m g ~ l}^{-1}$ & $\mathbf{~ m g ~ C O D ~ l}^{-1}$ \\
\hline Influent & 32,890 & 26,130 & 43 & 858 & 59,433 & 3,080 & 13,800 & 1,402 \\
\hline Effluent 1d & 20,833 & 13,244 & 444 & 4,700 & 22,300 & 7,167 & 9,660 & 1,334 \\
\hline Effluent 2d & 20,578 & 12,944 & 588 & 6,000 & 25,833 & 7,593 & 9,780 & 1,485 \\
\hline Effluent 3d & 20,489 & 12,300 & 750 & 5,775 & 25,000 & 8,867 & 9,240 & 2,012 \\
\hline
\end{tabular}

Table 12 Data for batch test of PS anaerobic fermentation $\mathrm{pH} 10.0$ at $35^{\circ} \mathrm{C}$

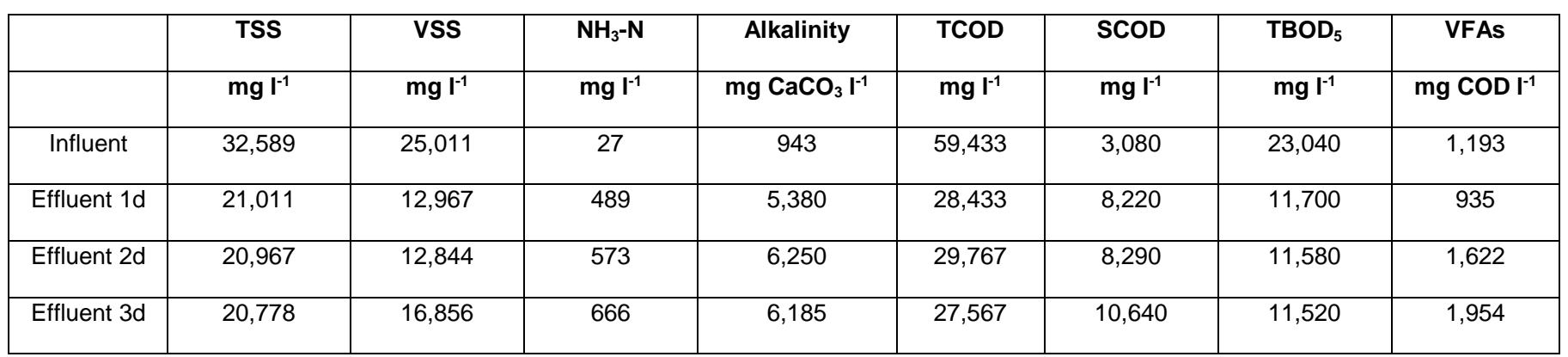

Table 13 Data for batch test of PS anaerobic fermentation $\mathrm{pH} 11.0$ at $35^{\circ} \mathrm{C}$

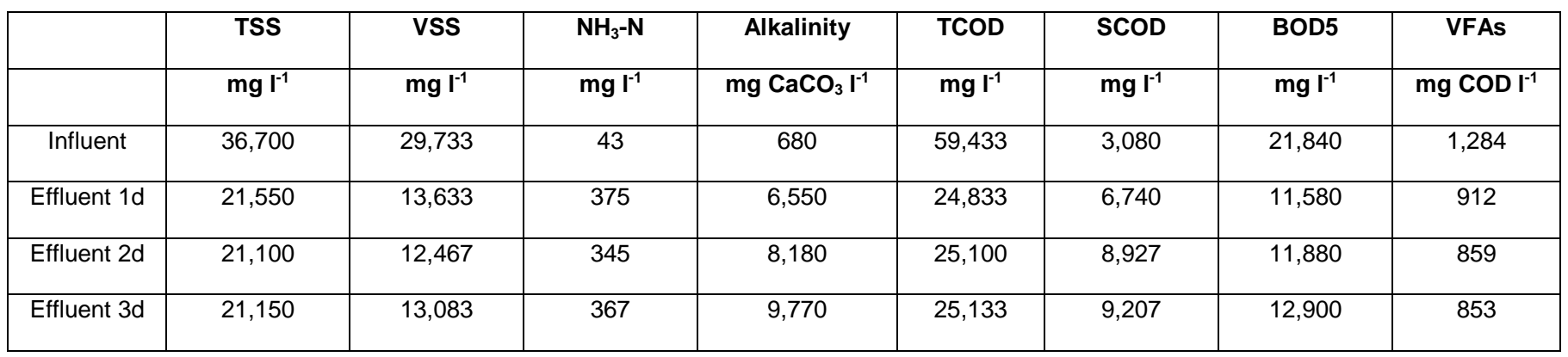




\section{B. Semi-continuous experiments}

Table 14 Data for semi-continuous PS anaerobic fermentation $\mathrm{pH} 4.5 \mathrm{HRT}=1$ days, $35^{\circ} \mathrm{C}$.

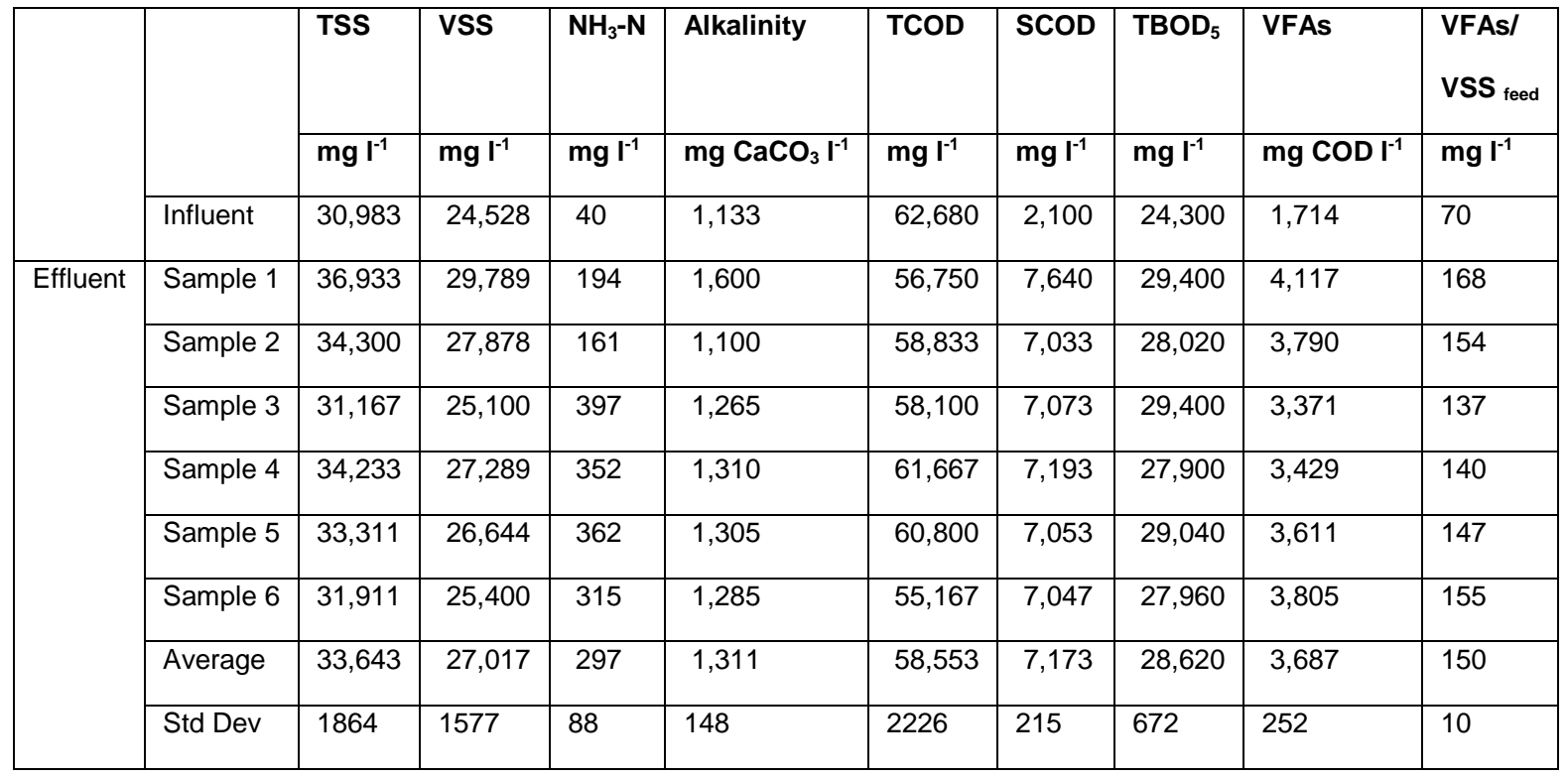

Table 15 Data for semi-continuous $P S$ anaerobic fermentation $\mathrm{pH} 4.5 \mathrm{HRT}=2$ days, $35^{\circ} \mathrm{C}$

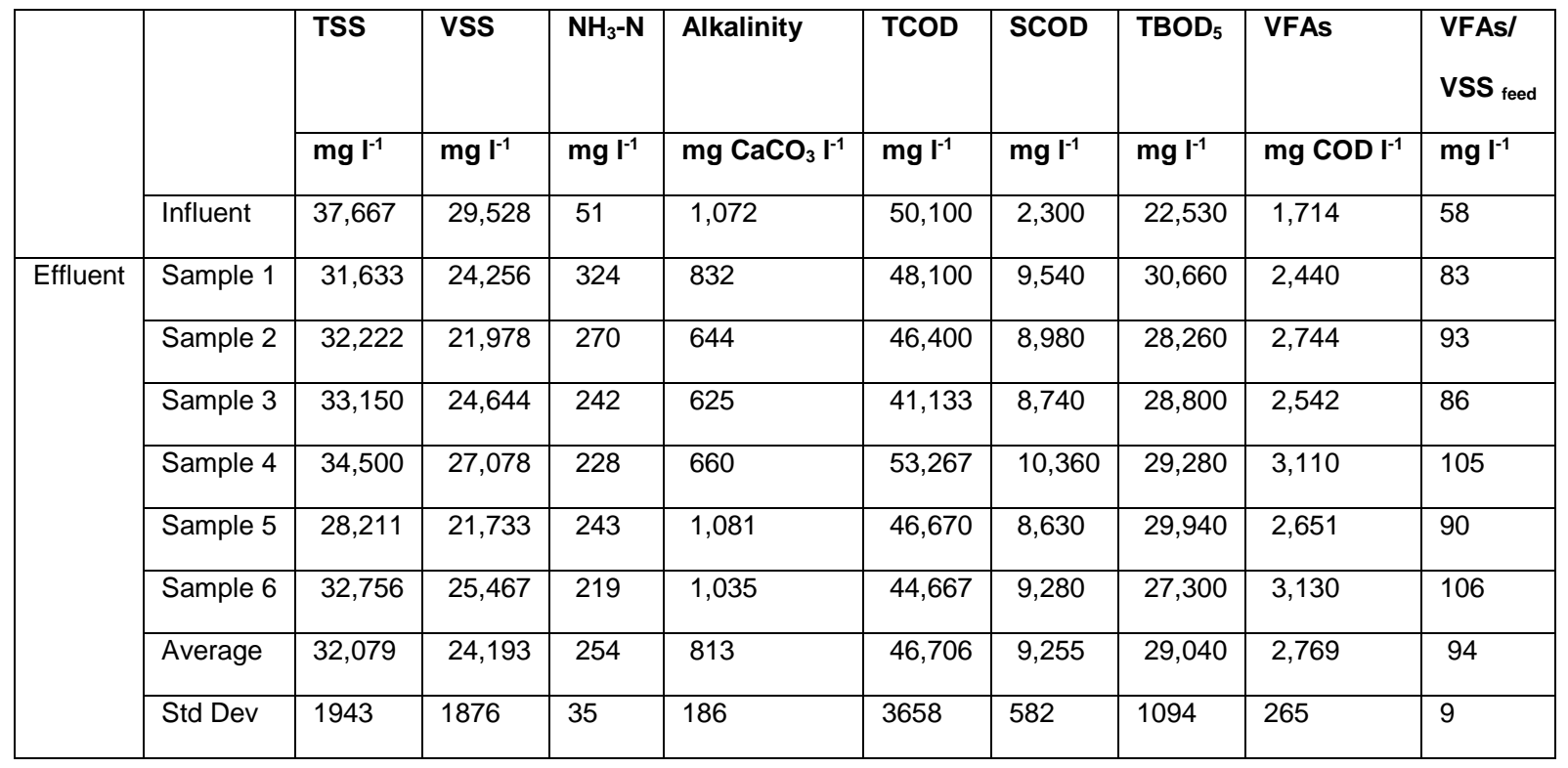


Table 16 Data for semi-continuous anaerobic fermentation $\mathrm{pH} 4.5 \mathrm{HRT}=3$ days, $35^{\circ} \mathrm{C}$

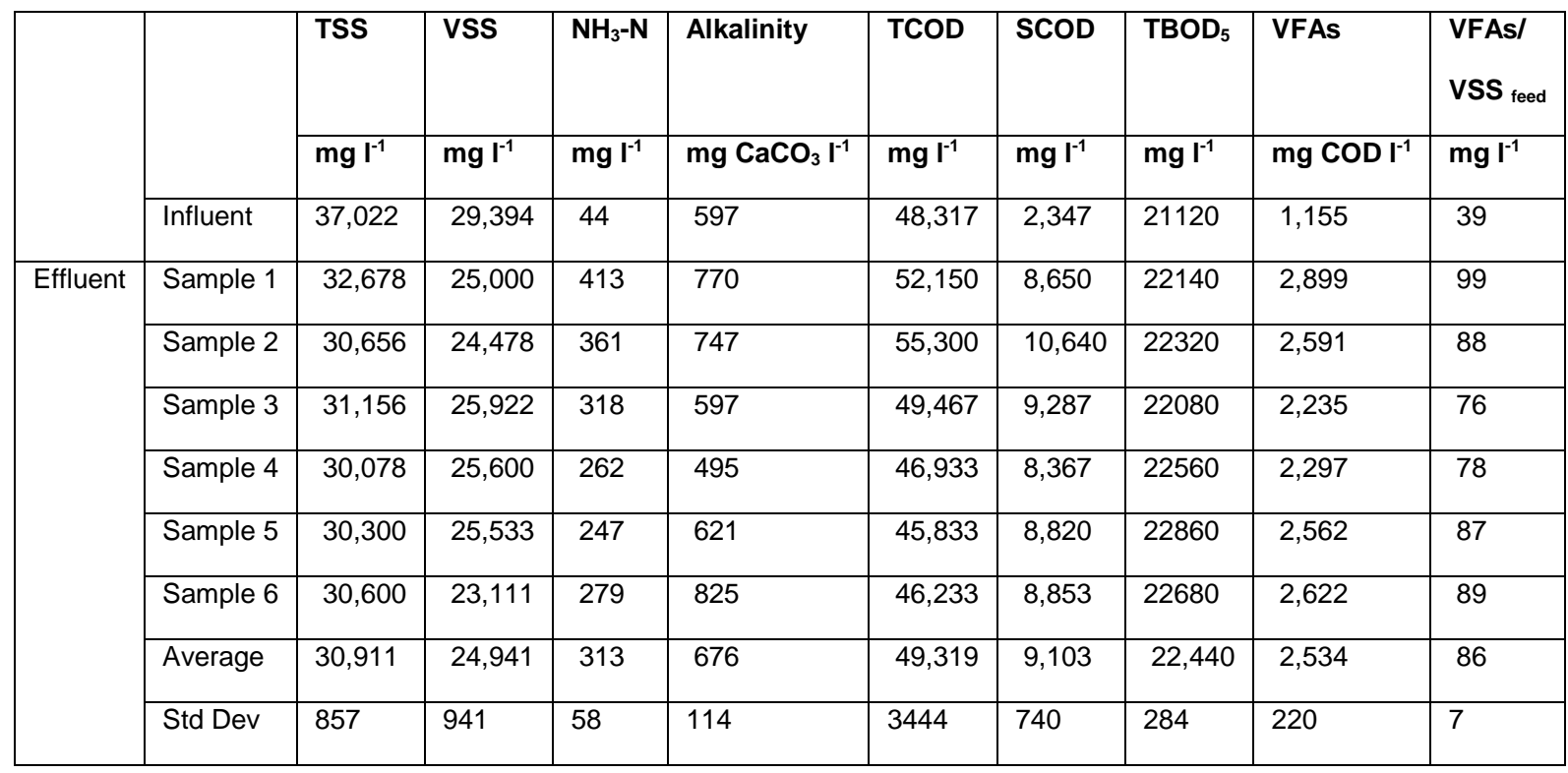

Table 17 Data for semi-continuous $P S$ anaerobic fermentation $p H 5.5 H R T=1$ days, $35^{\circ} \mathrm{C}$

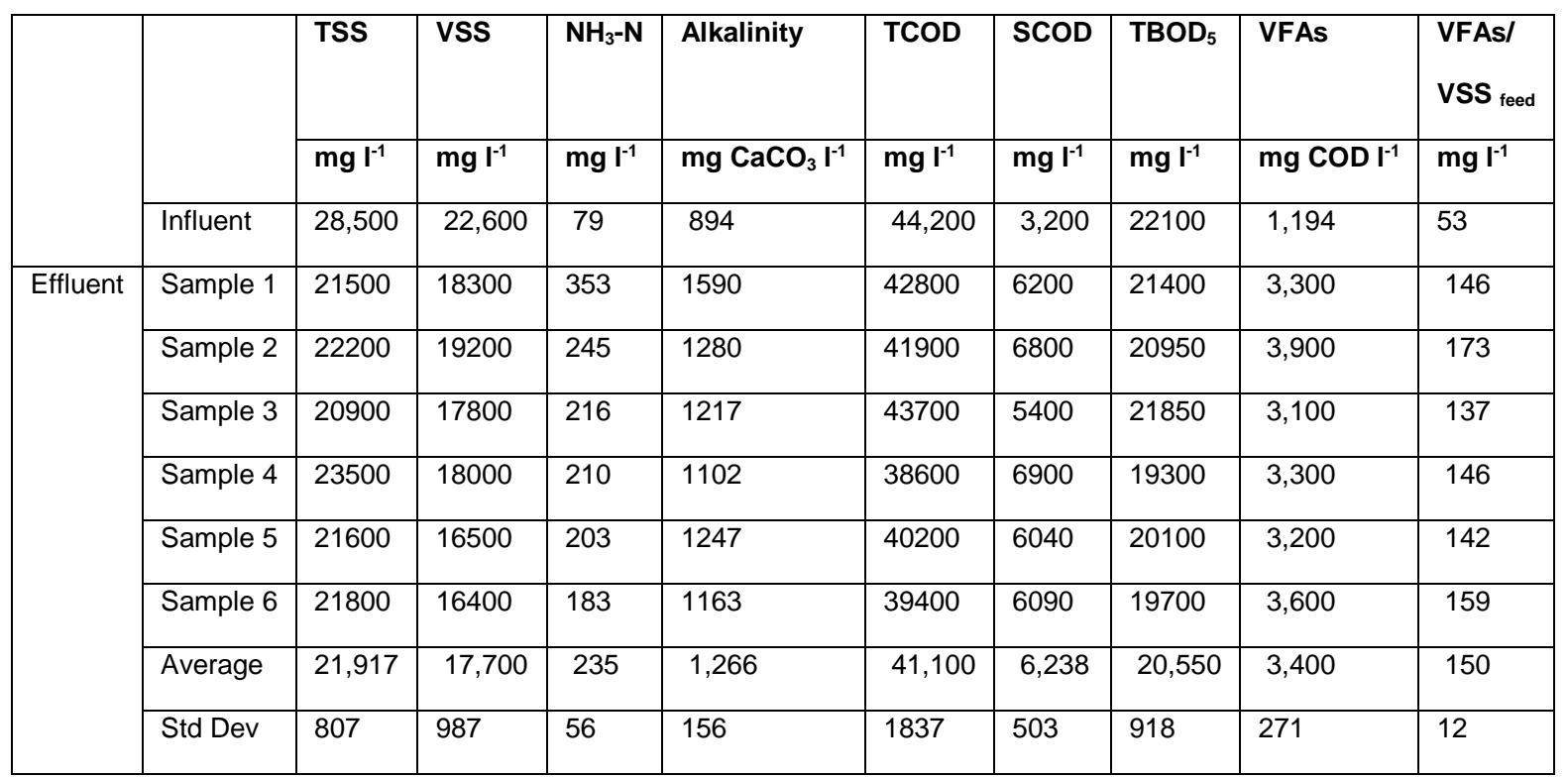


Table 18 Data for semi-continuous PS anaerobic fermentation $\mathrm{pH} 5.5 \mathrm{HRT}=2$ days, $35^{\circ} \mathrm{C}$.

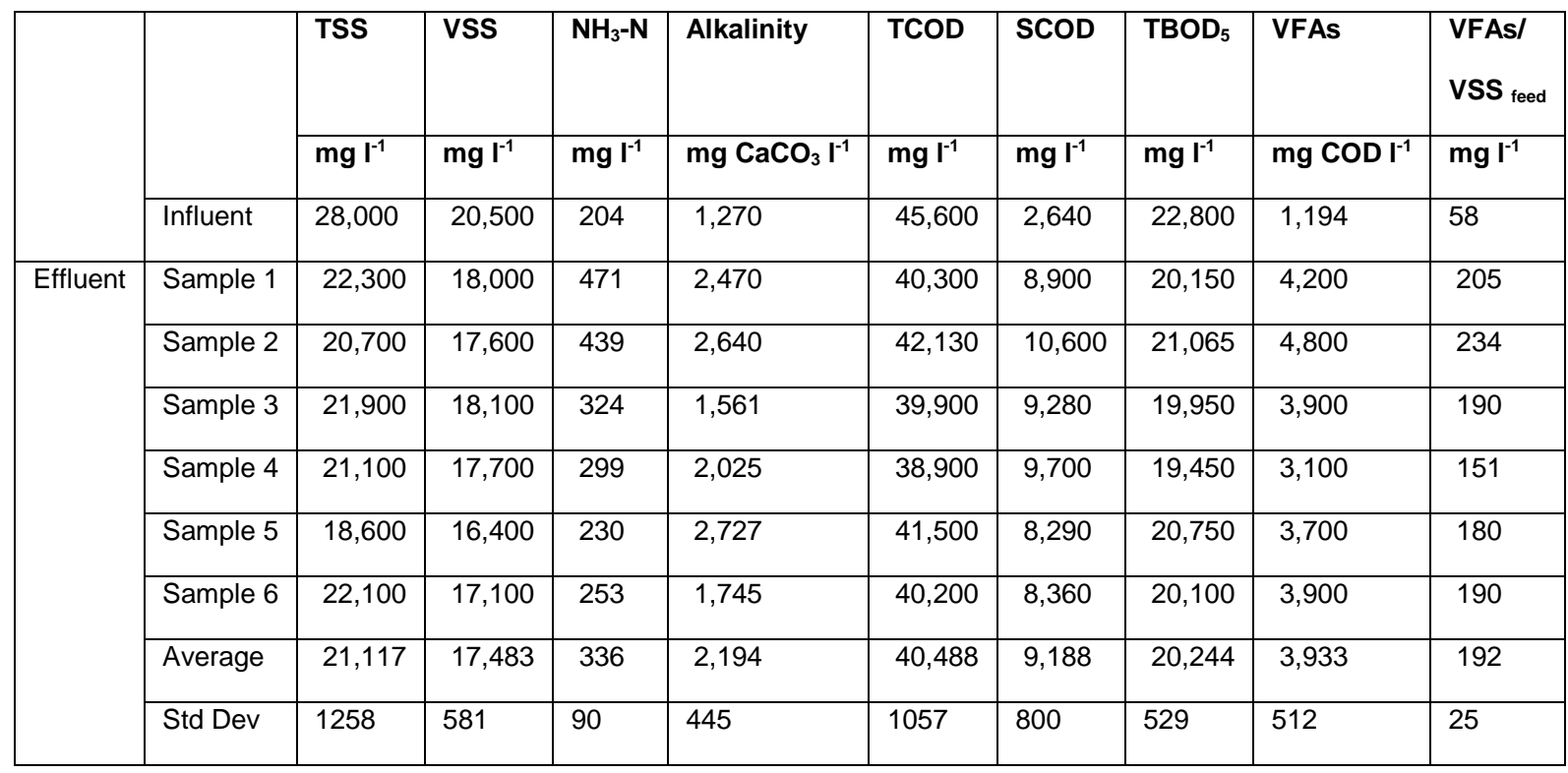

Table 19 Data for PS anaerobic fermentation semi-continuous study $\mathrm{pH} 5.5 \mathrm{HRT}=3$ days, $35^{\circ} \mathrm{C}$

\begin{tabular}{|c|c|c|c|c|c|c|c|c|c|c|}
\hline & & TSS & VSS & $\mathrm{NH}_{3}-\mathrm{N}$ & Alkalinity & TCOD & SCOD & TBOD $_{5}$ & VFAs & $\begin{array}{l}\text { VFAs/ } \\
\text { VSS }_{\text {feed }}\end{array}$ \\
\hline & & $\mathrm{mg} \mathrm{l}^{-1}$ & $\mathrm{mg} \mathrm{l}^{-1}$ & $\mathrm{mg} \mathrm{l}^{-1}$ & $\mathrm{mg} \mathrm{CaCO}_{3} \mathrm{I}^{-1}$ & $\mathrm{mg} \mathrm{l}^{-1}$ & $\mathrm{mg} \mathrm{l}^{-1}$ & $\mathrm{mg} \mathrm{l}^{-1}$ & $\mathrm{mg} \mathrm{COD} \mathrm{l}^{-1}$ & $\mathrm{mg} \mathrm{l}^{-1}$ \\
\hline & Influent & 30,983 & 24,528 & 40 & 1,133 & 42,580 & 2,100 & 21,300 & 1,714 & 70 \\
\hline \multirow[t]{8}{*}{ Effluent } & Sample 1 & 24,056 & 16,267 & 304 & 2,090 & 43,650 & 10,900 & 23,220 & 3,243 & 132 \\
\hline & Sample 2 & 25,133 & 18,189 & 137 & 1,460 & 40,460 & 10,360 & 22,320 & 3,396 & 138 \\
\hline & Sample 3 & 23,600 & 14,611 & 293 & 2,210 & 38,300 & 10,130 & 24,240 & 2,992 & 122 \\
\hline & Sample 4 & 24,178 & 16,144 & 282 & 2,135 & 45,050 & 9,850 & 22,800 & 2,891 & 118 \\
\hline & Sample 5 & 19,422 & 17,467 & 262 & 1,590 & 40,670 & 10,100 & 24,060 & 3,821 & 156 \\
\hline & Sample 6 & 22,756 & 15,678 & 245 & 1,520 & 39,270 & 9,600 & 24,960 & 2,837 & 116 \\
\hline & Average & 23,191 & 16,393 & 254 & 1,834 & 41,233 & 10,157 & 23,600 & 3,197 & 130 \\
\hline & Std Dev & 1828 & 1165 & 56 & 315 & 2373 & 409 & 903 & 341 & 14 \\
\hline
\end{tabular}


Table 20 Data for semi-continuous study of $P S$ anaerobic fermentation $p H 6.5 H R T=1$ days, $35^{\circ} \mathrm{C}$

\begin{tabular}{|c|c|c|c|c|c|c|c|c|c|c|}
\hline & & TSS & VSS & $\mathrm{NH}_{3}-\mathrm{N}$ & Alkalinity & TCOD & SCOD & TBOD $_{5}$ & VFAs & $\begin{array}{l}\text { VFAs/ } \\
\text { VSS }_{\text {feed }}\end{array}$ \\
\hline & & $\mathrm{mg} \mathrm{l}^{-1}$ & $\mathrm{mg} \mathrm{l}^{-1}$ & $\mathrm{mg} \mathrm{l}^{-1}$ & $\mathrm{mg} \mathrm{CaCO}_{3} \mathrm{I}^{-1}$ & $\mathrm{mg} \mathrm{l}^{-1}$ & $\mathrm{mg} \mathrm{l}^{-1}$ & $\mathrm{mg} \mathrm{l}^{-1}$ & $\mathrm{mg} \mathrm{COD} \mathrm{l}^{-1}$ & $\mathrm{mg} \mathrm{l}^{-1}$ \\
\hline & Influent & 27,922 & 22,589 & 47 & 657 & 47,967 & 3,580 & 17,100 & 1,379 & 27,922 \\
\hline \multirow[t]{8}{*}{ Effluent } & Sample 1 & 21,989 & 16,778 & 359 & 2,545 & 49,650 & 7,390 & 15,300 & 2,393 & 21,989 \\
\hline & Sample 2 & 22,211 & 16,944 & 323 & 2,270 & 43,100 & 7,140 & 15,540 & 1,982 & 22,211 \\
\hline & Sample 3 & 21,444 & 16,122 & 365 & 2,840 & 48,100 & 7,147 & 15,840 & 2,957 & 21,444 \\
\hline & Sample 4 & 21,722 & 16,578 & 341 & 2,545 & 49,367 & 7,340 & 15,060 & 3,078 & 21,722 \\
\hline & Sample 5 & 21,333 & 16,044 & 377 & 2,810 & 47,500 & 7,267 & 15,660 & 2,301 & 21,333 \\
\hline & Sample 6 & 21,844 & 16,200 & 373 & 2,460 & 52,933 & 7,247 & 15,360 & 2,101 & 21,844 \\
\hline & Average & 21,757 & 16,444 & 356 & 2,578 & 48,442 & 7,255 & 15,460 & 2,469 & 21,757 \\
\hline & Std Dev & 302 & 342 & 19 & 197 & 2945 & 92 & 254 & 412 & 302 \\
\hline
\end{tabular}

Table 21 Data for semi-continuous study of $P S$ anaerobic fermentation $p H 6.5 H R T=2$ days, $35^{\circ} \mathrm{C}$

\begin{tabular}{|c|c|c|c|c|c|c|c|c|c|c|}
\hline & & TSS & VSS & $\mathrm{NH}_{3}-\mathrm{N}$ & Alkalinity & TCOD & SCOD & TBOD $_{5}$ & VFAs & $\begin{array}{l}\text { VFAs/ } \\
\text { VSS }_{\text {feed }}\end{array}$ \\
\hline & & $\mathrm{mg} \mathrm{l}^{-1}$ & $\mathrm{mg} \mathrm{l}^{-1}$ & $\mathrm{mg} \mathrm{l}^{-1}$ & $\mathrm{mg} \mathrm{CaCO}_{3} \mathrm{I}^{-1}$ & $\mathrm{mg} \mathrm{l}^{-1}$ & $\mathrm{mg} \mathrm{l}^{-1}$ & $\mathrm{mg} \mathrm{l}^{-1}$ & ${\mathrm{mg} \mathrm{COD} \mathrm{l}^{-1}}$ & $\mathrm{mg} \mathrm{l}^{-1}$ \\
\hline & Influent & 48,011 & 38,678 & 47 & 1,145 & 46,067 & 3,580 & 13,680 & 1,554 & \\
\hline \multirow[t]{8}{*}{ Effluent } & Sample 1 & 28,022 & 20,100 & 468 & 4,655 & 52,750 & 14,320 & 33,773 & 4,453 & 76 \\
\hline & Sample 2 & 34,956 & 26,144 & 458 & 3,400 & 52,967 & 14,340 & 34,359 & 4,397 & 114 \\
\hline & Sample 3 & 30,467 & 22,556 & 464 & 3,800 & 46,500 & 14,767 & 35,281 & 4,768 & 123 \\
\hline & Sample 4 & 29,822 & 20,456 & 361 & 3,520 & 51,333 & 14,393 & 32,348 & 5,414 & 140 \\
\hline & Sample 5 & 28,911 & 19,722 & 377 & 3,105 & 52,633 & 14,173 & 32,097 & 5,097 & 132 \\
\hline & Sample 6 & 30,411 & 20,711 & 312 & 3,315 & 54,567 & 14,267 & 31,510 & 4,562 & 118 \\
\hline & Average & 30,431 & 21,615 & 407 & 3,633 & 51,792 & 14,377 & 33,228 & 4,782 & 117 \\
\hline & Std Dev & 2197 & 2215 & 60 & 503 & 2547 & 187 & 1342 & 366 & 20 \\
\hline
\end{tabular}


Table 22 Data for semi-continuous study of $P S$ anaerobic fermentation $\mathrm{pH} 6.5 \mathrm{HRT}=3$ days, $35^{\circ} \mathrm{C}$

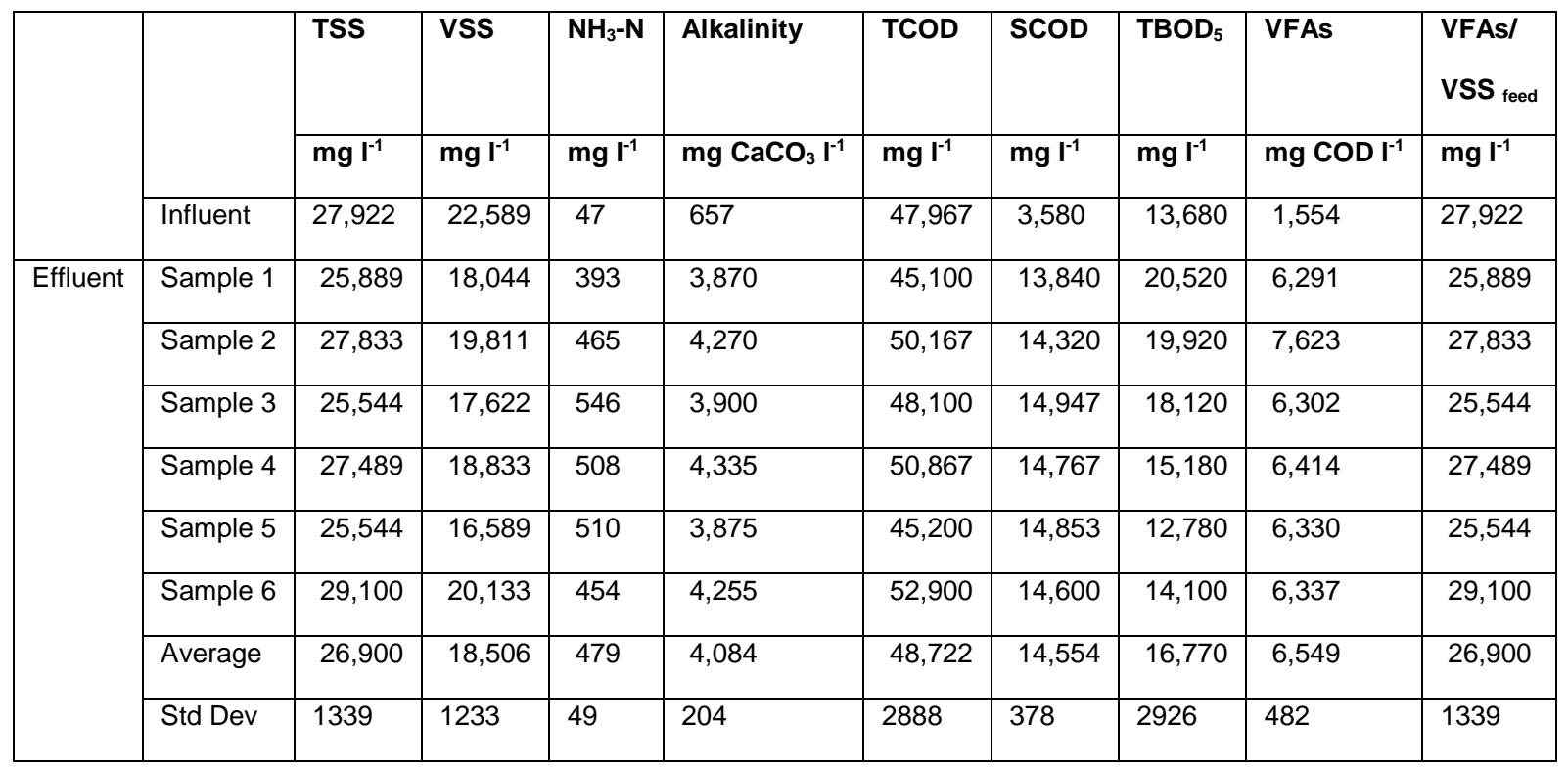

Table 23 VFAs yield, SCOD yield, VFAS/SCOD, degree of solubilization data for semi-continuous study of PS anaerobic fermentation $35^{\circ} \mathrm{C}$

\begin{tabular}{|c|c|c|c|c|c|}
\hline $\mathrm{pH}$ & HRT & VFAs/SCOD & VFAs yield & SCOD yield & $\begin{array}{c}\text { degree of } \\
\text { solubilization }\end{array}$ \\
\hline & d & $\begin{array}{c}\text { mg COD } \text { mg }^{-1} \text { SCOD } \\
(\%)\end{array}$ & $\mathrm{mg} \mathrm{COD} \mathrm{g}^{-1} \mathrm{VSS}_{\text {feed }}$ & $\mathrm{mg} \mathrm{SCOD}^{-1} \mathrm{VSS}_{\text {feed }}$ & $\%$ \\
\hline 4.5 & 0 & 64 & 58 & 92 & \\
\hline 4.5 & 1 & 51 & 150 & 292 & 8 \\
\hline 4.5 & 2 & 30 & 94 & 313 & 15 \\
\hline 4.5 & 3 & 28 & 86 & 310 & 15 \\
\hline 5.5 & 0 & 52 & 61 & 117 & \\
\hline 5.5 & 1 & 55 & 150 & 276 & 7 \\
\hline 5.5 & 2 & 43 & 192 & 448 & 15 \\
\hline 5.5 & 3 & 31 & 130 & 414 & 20 \\
\hline 6.5 & 0 & 41 & 65 & 158 & \\
\hline 6.5 & 1 & 34 & 109 & 321 & 8 \\
\hline 6.5 & 2 & 32 & 117 & 372 & 25 \\
\hline 6.5 & 3 & 45 & 290 & 644 & 25 \\
\hline
\end{tabular}


C. One-way ANOVA, Fisher pairwise comparison for batch experiment

\section{One-way ANOVA: VFAs yield versus $\mathrm{pH}$}

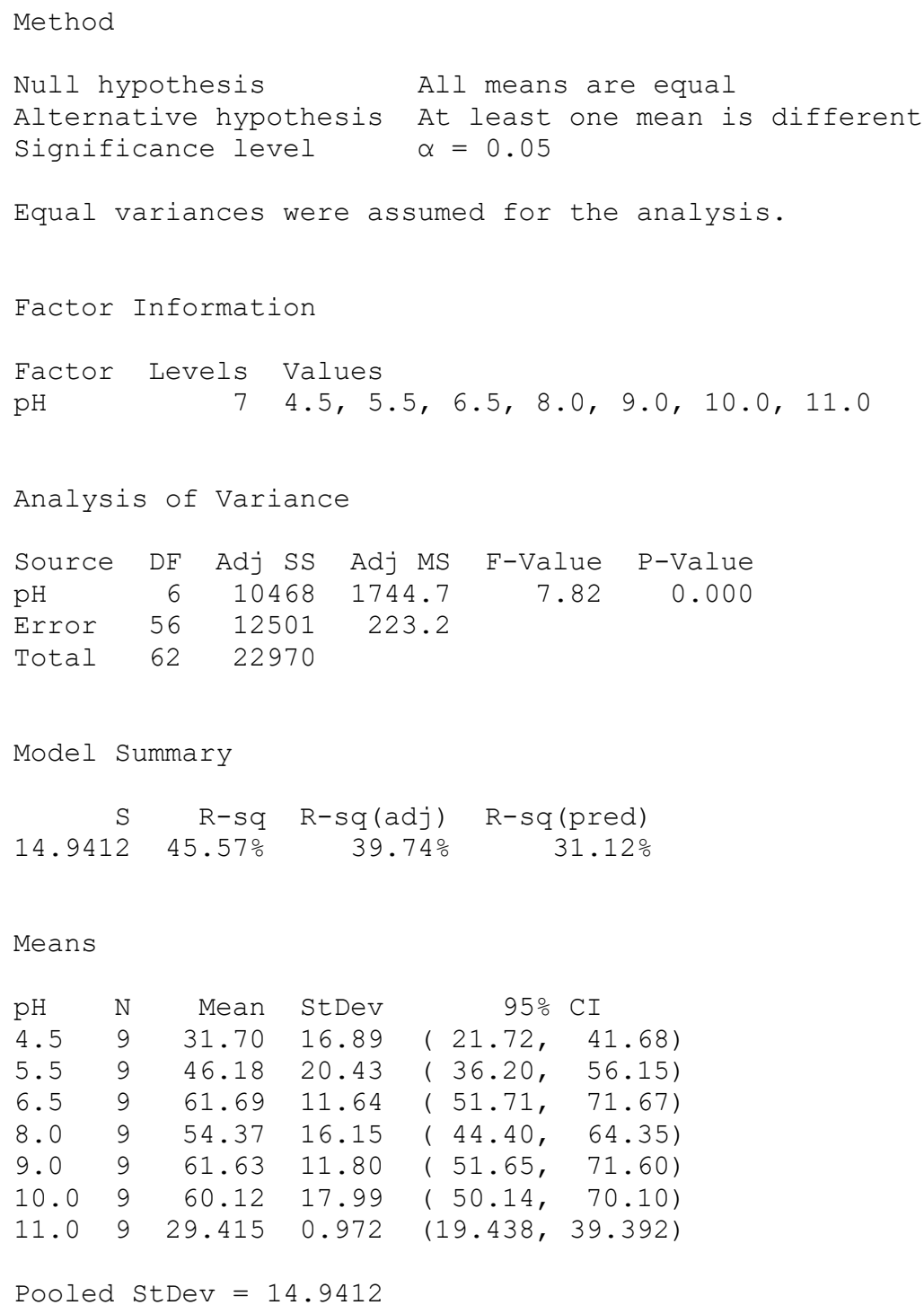

Pooled StDev $=14.9412$

\section{Fisher Pairwise Comparisons}

\begin{tabular}{|c|c|c|c|c|c|c|}
\hline Difference & Difference & SE of & & & & Adjusted \\
\hline of Levels & of Means & Difference & $95 \%$ & CI & T-Value & P-Value \\
\hline $5.5-4.5$ & 14.48 & 7.04 & 0.37, & $28.59)$ & 2.06 & 0.045 \\
\hline $6.5-4.5$ & 29.99 & 7.04 & ( 15.88, & $44.10)$ & 4.26 & 0.000 \\
\hline $8.0-4.5$ & 22.67 & 7.04 & 8.56, & $36.78)$ & 3.22 & 0.002 \\
\hline $9.0-4.5$ & 29.93 & 7.04 & ( 15.82, & $44.04)$ & 4.25 & 0.000 \\
\hline $10.0-4.5$ & 28.42 & 7.04 & ( 14.31, & $42.53)$ & 4.04 & 0.000 \\
\hline $11.0-4.5$ & -2.28 & 7.04 & $(-16.39)$ & $11.83)$ & -0.32 & 0.747 \\
\hline $6.5-5.5$ & 15.51 & 7.04 & 1.40, & $29.62)$ & 2.20 & 0.032 \\
\hline
\end{tabular}




$\begin{array}{lrrrrrr}8.0-5.5 & 8.20 & 7.04 & (-5.91, & 22.31) & 1.16 & 0.250 \\ 9.0-5.5 & 15.45 & 7.04 & (1.34, & 29.56) & 2.19 & 0.032 \\ 10.0-5.5 & 13.94 & 7.04 & (-0.17, & 28.05) & 1.98 & 0.053 \\ 11.0-5.5 & -16.76 & 7.04 & (-30.87, & -2.65) & -2.38 & 0.021 \\ 8.0-6.5 & -7.32 & 7.04 & (-21.43, & 6.79) & -1.04 & 0.303 \\ 9.0-6.5 & -0.06 & 7.04 & (-14.17, & 14.05) & -0.01 & 0.993 \\ 10.0-6.5 & -1.57 & 7.04 & (-15.68, & 12.54) & -0.22 & 0.825 \\ 11.0-6.5 & -32.27 & 7.04 & (-46.38,-18.16) & -4.58 & 0.000 \\ 9.0-8.0 & 7.25 & 7.04 & (-6.86, & 21.36) & 1.03 & 0.308 \\ 10.0-8.0 & 5.75 & 7.04 & (-8.36, & 19.86) & 0.82 & 0.418 \\ 11.0-8.0 & -24.96 & 7.04 & (-39.07,-10.85) & -3.54 & 0.001 \\ 10.0-9.0 & -1.51 & 7.04 & (-15.61, & 12.60) & -0.21 & 0.832 \\ 11.0-9.0 & -32.21 & 7.04 & (-46.32,-18.10) & -4.57 & 0.000 \\ 11.0-10.0 & -30.71 & 7.04 & (-44.81,-16.60) & -4.36 & 0.000\end{array}$

Simultaneous confidence level $=57.58 \%$

\section{One-way ANOVA: VFAs yield versus Time}

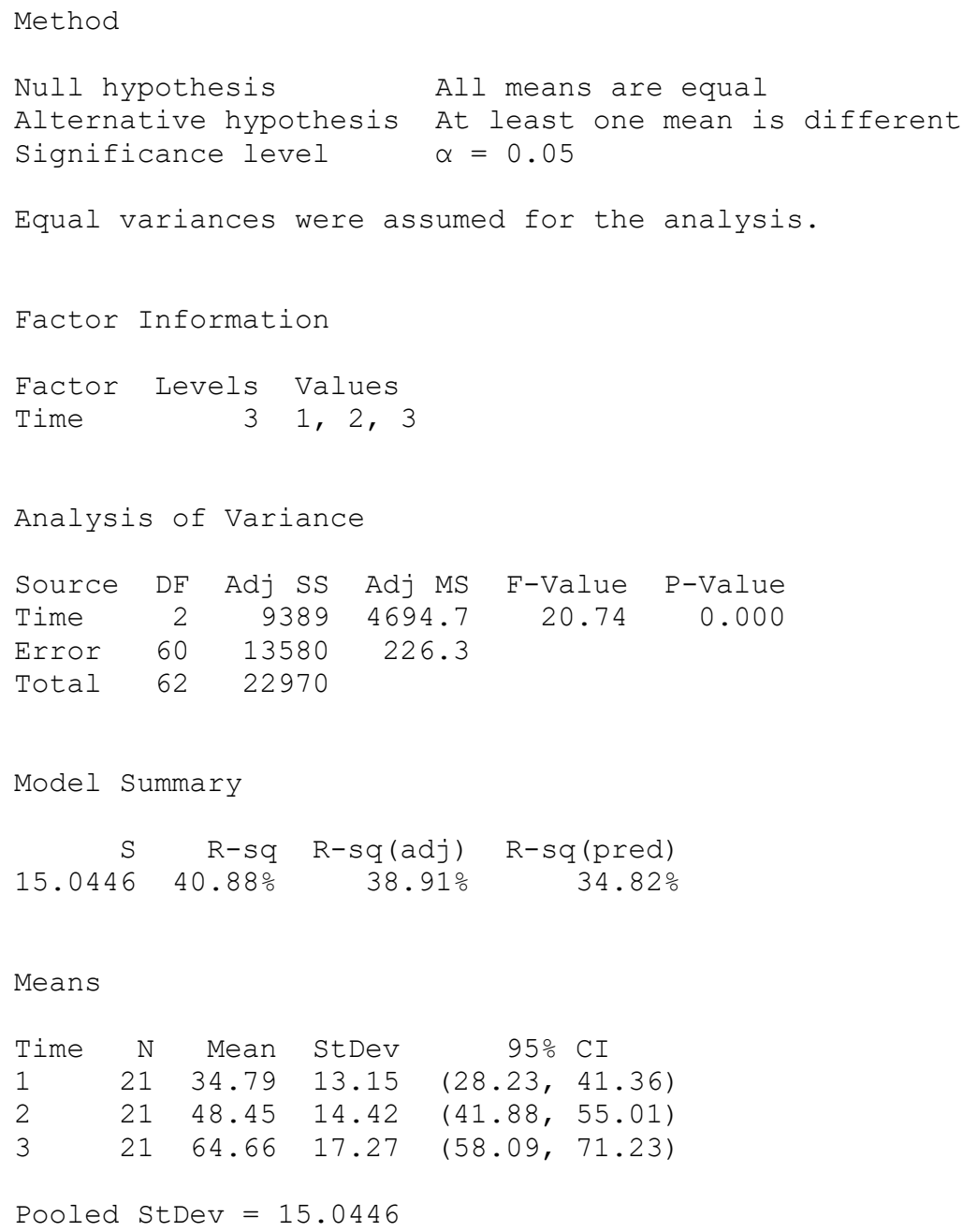




\section{Fisher Pairwise Comparisons}

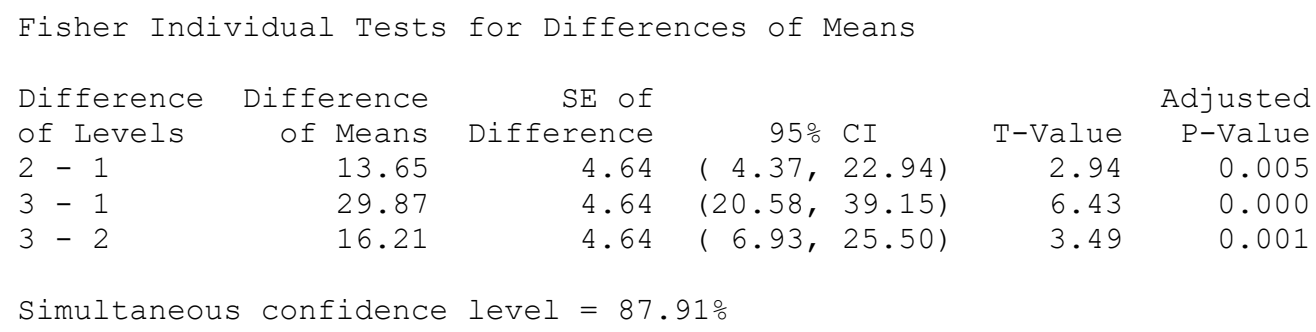

One-way ANOVA: SCOD yield versus pH

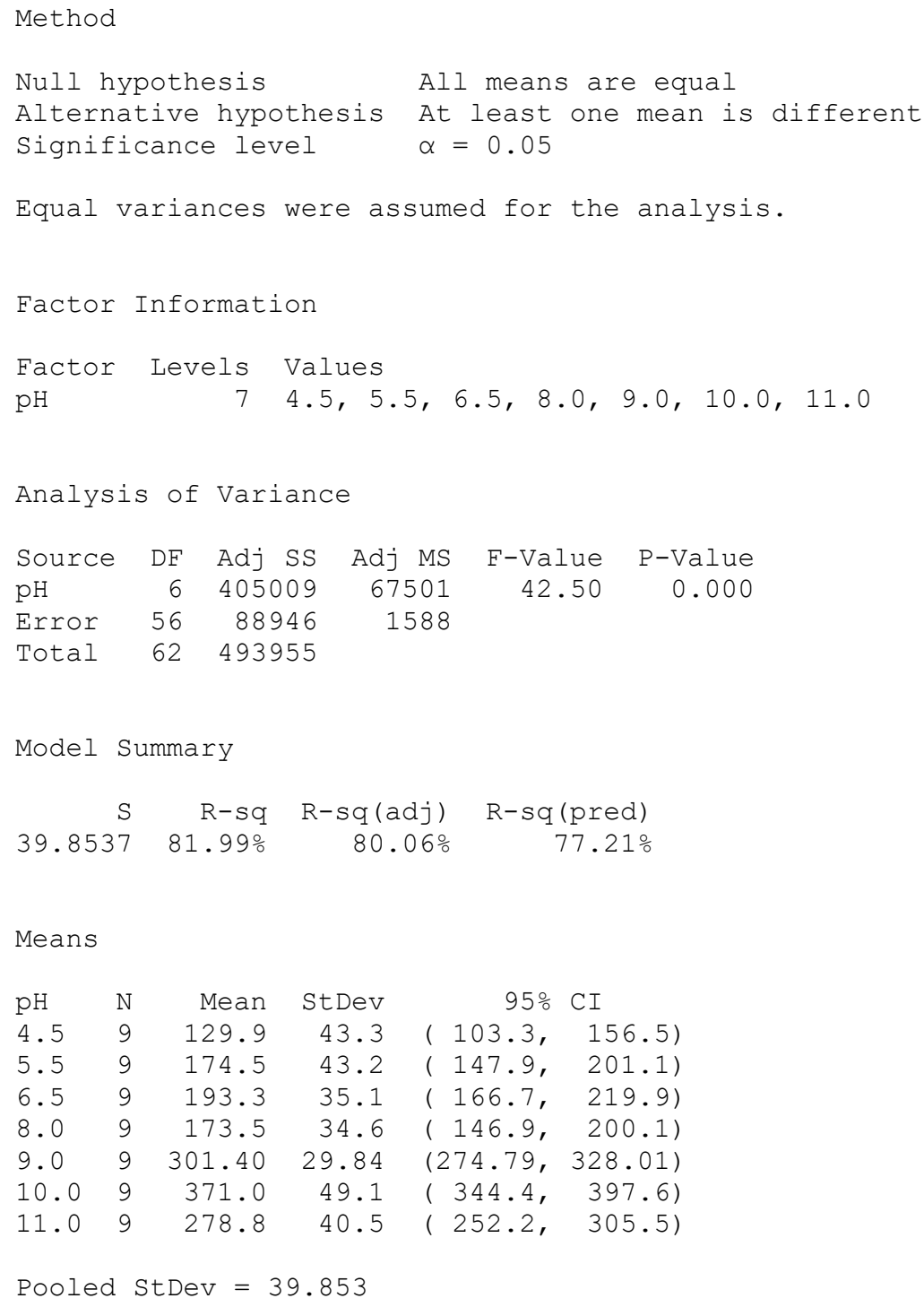


Fisher Pairwise Comparisons

\begin{tabular}{|c|c|c|c|c|c|c|}
\hline Difference & Difference & SE of & & & & Adjusted \\
\hline of Levels & of Means & Difference & $95 \%$ & CI & T-Value & \\
\hline $5.5-4.5$ & 44.6 & 18.8 & 7.0 , & 82.31 & 2.38 & 0.021 \\
\hline $6.5-4.5$ & 63.5 & 18.8 & 25.8, & $101.1)$ & 3.38 & 0.001 \\
\hline $8.0-4.5$ & 43.6 & 18.8 & 6.0, & $81.2)$ & 2.32 & 0.024 \\
\hline $9.0-4.5$ & 171.5 & 18.8 & ( 133.9, & 209.21 & 9.13 & 0.000 \\
\hline $10.0-4.5$ & 241.2 & 18.8 & ( 203.5, & $278.8)$ & 12.84 & 0.000 \\
\hline $11.0-4.5$ & 149.0 & 18.8 & ( 111.3, & $186.6)$ & 7.93 & 0.000 \\
\hline $6.5-5.5$ & 18.8 & 18.8 & $(-18.8$ & $56.5)$ & 1.00 & 0.320 \\
\hline $8.0-5.5$ & -1.0 & 18.8 & $(-38.7$, & $36.6)$ & -0.05 & 0.956 \\
\hline $9.0-5.5$ & 126.9 & 18.8 & 89.3, & $164.5)$ & 6.75 & 0.000 \\
\hline $10.0-5.5$ & 196.5 & 18.8 & ( 158.9, & 234.21 & 10.46 & 0.000 \\
\hline $11.0-5.5$ & 104.4 & 18.8 & 66.7, & $142.0)$ & 5.55 & 0.000 \\
\hline $8.0-6.5$ & -19.9 & 18.8 & $(-57.5$, & $17.8)$ & -1.06 & 0.295 \\
\hline $9.0-6.5$ & 108.1 & 18.8 & 70.4 & $145.7)$ & 5.75 & 0.000 \\
\hline $10.0-6.5$ & 177.7 & 18.8 & ( 140.1, & $215.3)$ & 9.46 & 0.000 \\
\hline $11.0-6.5$ & 85.5 & 18.8 & 47.9, & $123.1)$ & 4.55 & 0.000 \\
\hline $9.0-8.0$ & 127.9 & 18.8 & 90.3, & $165.6)$ & 6.81 & 0.000 \\
\hline $10.0-8.0$ & 197.6 & 18.8 & ( 159.9, & 235.21 & 10.52 & 0.000 \\
\hline $11.0-8.0$ & 105.4 & 18.8 & 67.8, & $143.0)$ & 5.61 & 0.000 \\
\hline $10.0-9.0$ & 69.6 & 18.8 & 32.0, & $107.3)$ & 3.71 & 0.000 \\
\hline $11.0-9.0$ & -22.5 & 18.8 & $(-60.2$, & $15.1)$ & -1.20 & 0.235 \\
\hline $11.0-10.0$ & -92.2 & 18.8 & $(-129.8$, & $-54.6)$ & -4.91 & 0.000 \\
\hline
\end{tabular}

Simultaneous confidence level $=57.58 \%$

One-way ANOVA: SCOD yield versus Time

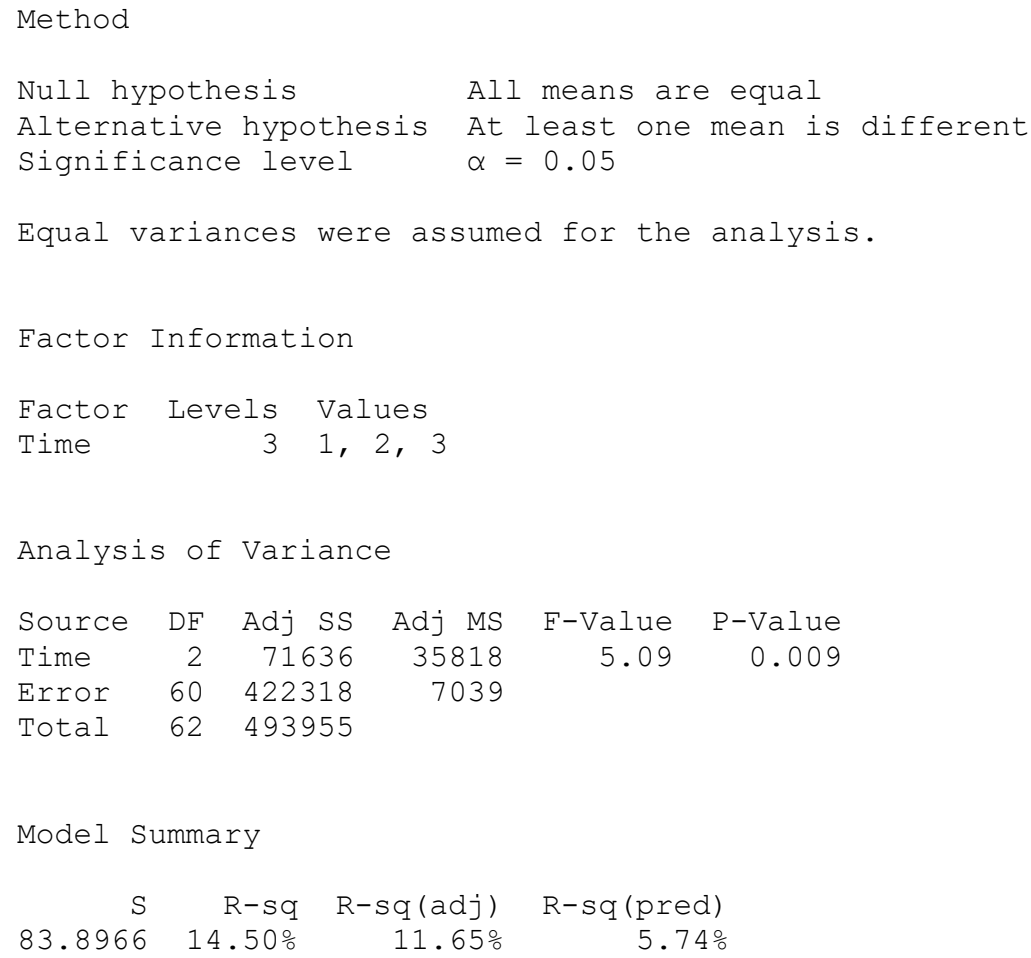




\begin{tabular}{|c|c|c|c|c|c|}
\hline Time & $\mathrm{N}$ & Mean & StDev & $95 \%$ & CI \\
\hline 1 & 21 & 187.3 & 87.2 & (150.7, & $224.0)$ \\
\hline 2 & 21 & 239.0 & 76.3 & (202.4, & $275.6)$ \\
\hline & 21 & 269.0 & 87.7 & (232.4 & $305.6)$ \\
\hline
\end{tabular}

Pooled StDev $=83.8966$

\section{Fisher Pairwise Comparisons}

\begin{tabular}{|c|c|c|c|c|c|c|}
\hline Difference & Difference & $S E$ of & & & & Adjusted \\
\hline of Levels & of Means & Difference & $95 \%$ & CI & T-Value & P-Value \\
\hline $2-1$ & 51.7 & 25.9 & $(-0.1$, & $103.5)$ & 2.00 & 0.050 \\
\hline $3-1$ & 81.6 & 25.9 & ( 29.9, & $133.4)$ & 3.15 & 0.003 \\
\hline $3-2$ & 30.0 & 25.9 & $(-21.8$ & $81.8)$ & 1.16 & 0.252 \\
\hline
\end{tabular}


D. One-way ANOVA, Fisher pairwise comparison for semi-continuous experiment One-way ANOVA: VFAs yield versus pH

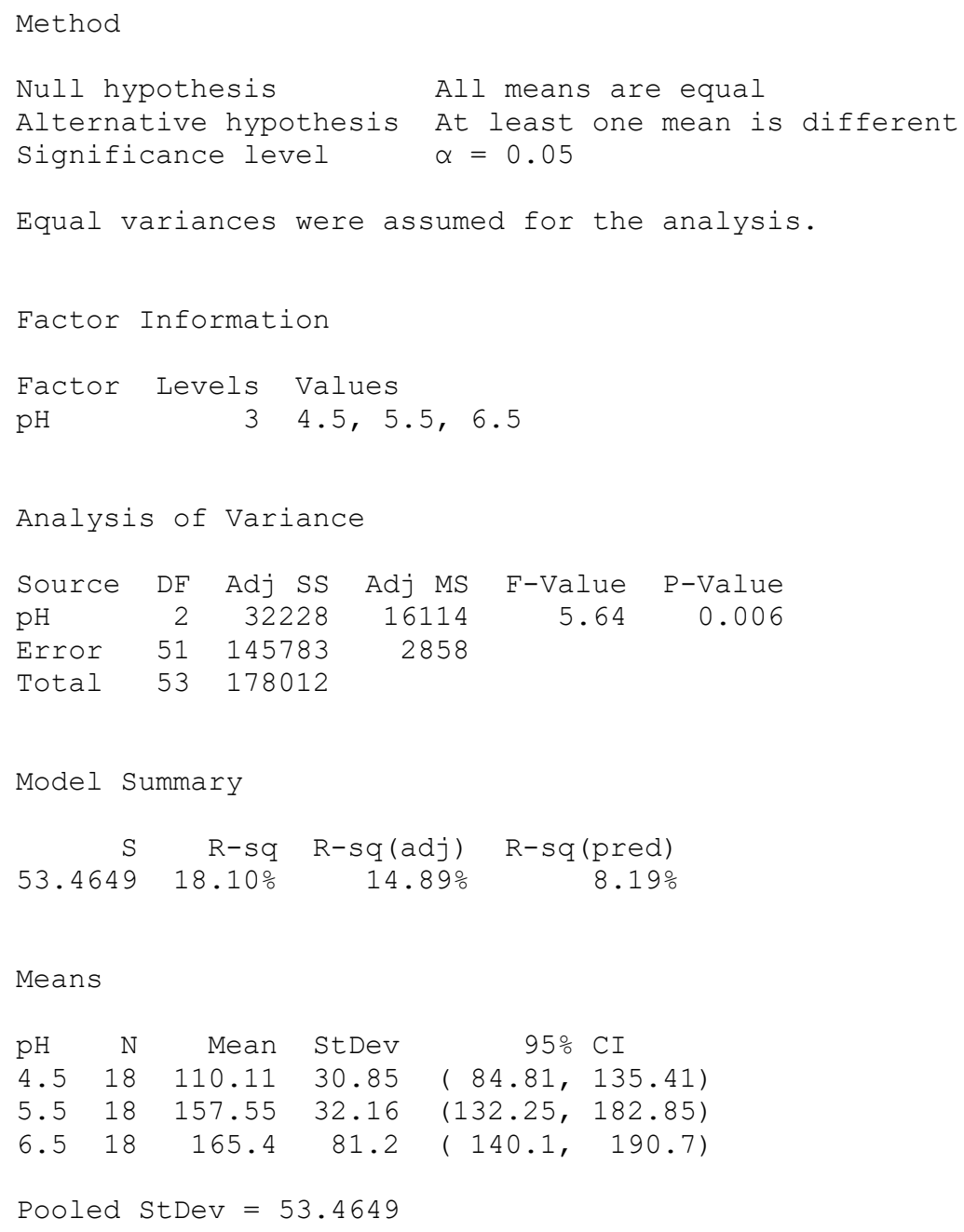

\section{Fisher Pairwise Comparisons}

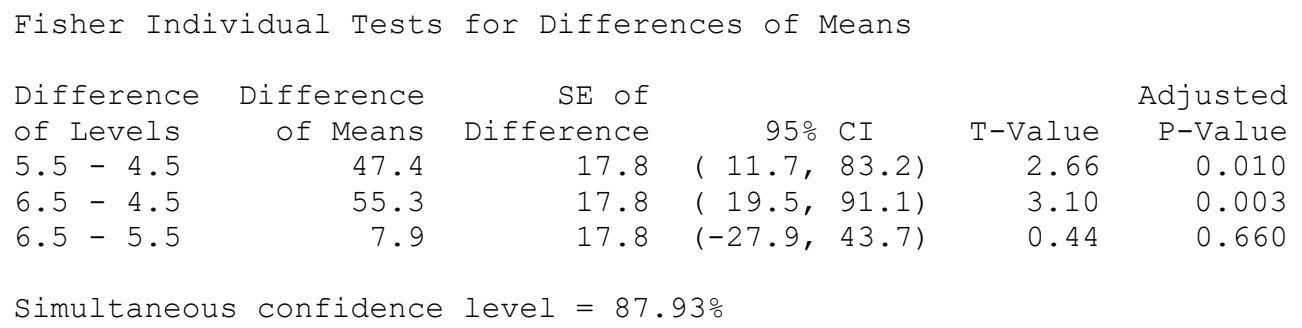




\section{One-way ANOVA: SCOD yield versus $\mathrm{pH}$}

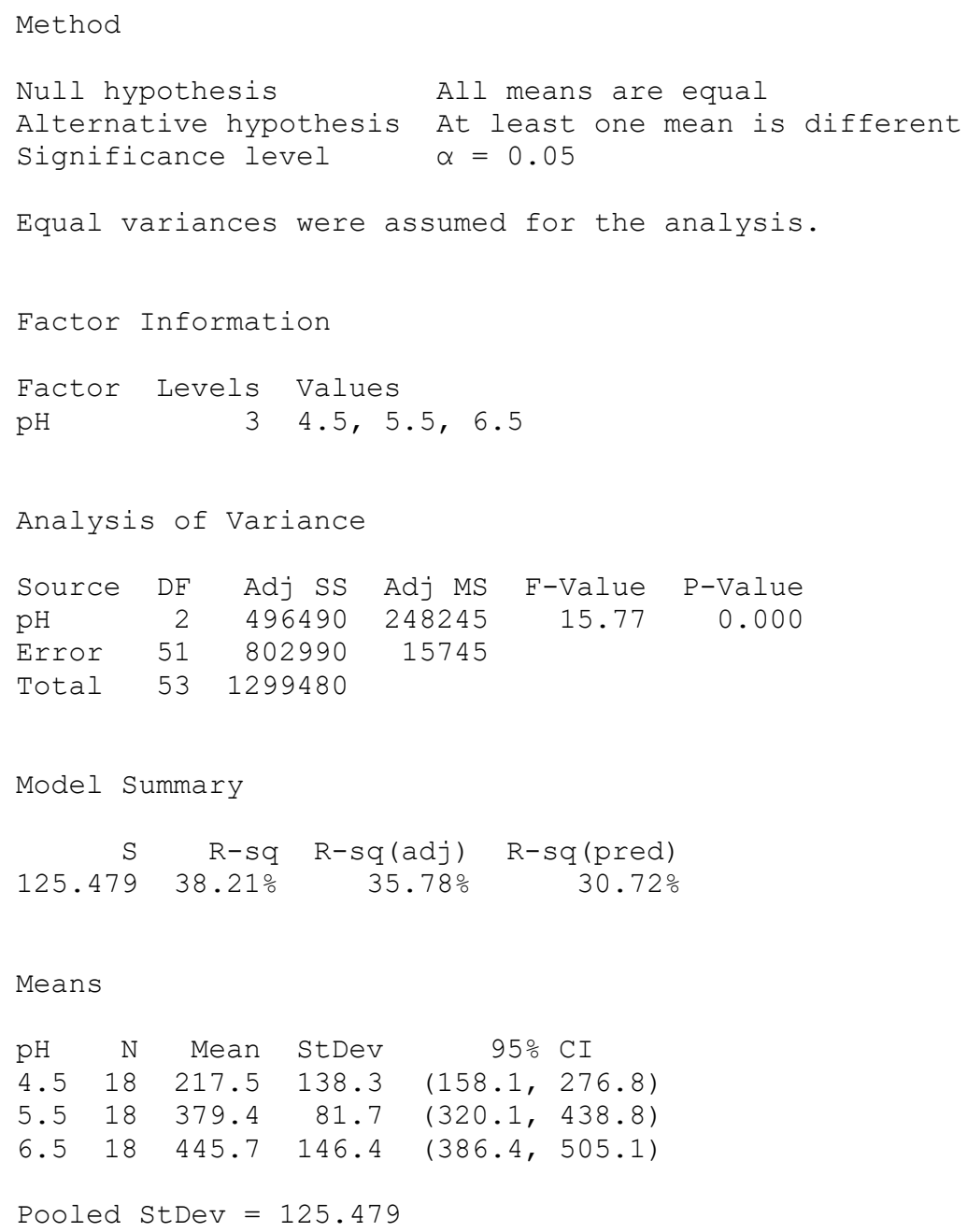

\section{Fisher Pairwise Comparisons}

\begin{tabular}{|c|c|c|c|c|c|c|}
\hline Difference & Difference & SE of & & & & Adjusted \\
\hline of Levels & of Means & Difference & $95 \%$ & $\mathrm{CI}$ & T-Value & P-Value \\
\hline $5.5-4.5$ & 162.0 & 41.8 & $(78.0$ & 246.01 & 3.87 & 0.000 \\
\hline $6.5-4.5$ & 228.3 & 41.8 & (144.3, & $312.3)$ & 5.46 & 0.000 \\
\hline $6.5-5.5$ & 66.3 & 41.8 & $(-17.7$ & $150.3)$ & 1.58 & 0.119 \\
\hline
\end{tabular}

Simultaneous confidence level $=87.93 \%$ 


\section{References}

[1] S. Bengtsson, J. Hallquist, A. Werker, and T. Welander, "Acidogenic fermentation of industrial wastewaters: Effects of chemostat retention time and $\mathrm{pH}$ on volatile fatty acids production," Biochem. Eng. J., vol. 40, no. 3, pp. 492-499, 2008.

[2] H. Su, J. Cheng, J. Zhou, W. Song, and K. Cen, "Improving hydrogen production from cassava starch by combination of dark and photo fermentation," Int. J. Hydrogen Energy, vol. 34, no. 4, pp. 1780-1786, 2009.

[3] W. S. Lee, A. S. M. Chua, H. K. Yeoh, and G. C. Ngoh, "A review of the production and applications of waste-derived volatile fatty acids," Chemical Engineering Journal. 2014.

[4] P. Weiland, "Biogas production: Current state and perspectives," Applied Microbiology and Biotechnology, vol. 85, no. 4. pp. 849-860, 2010.

[5] Z. Ji, G. Chen, and Y. Chen, "Effects of waste activated sludge and surfactant addition on primary sludge hydrolysis and short-chain fatty acids accumulation," Bioresour. Technol., vol. 101, no. 10, pp. 3457-3462, 2010.

[6] I. Maharaj and P. Elefsiniotis, "The role of HRT and low temperature on the acidphase anaerobic digestion of municipal and industrial wastewaters," Bioresour. Technol., vol. 76, no. 3, pp. 191-197, 2001.

[7] P. Elefsiniotis and W. K. Oldham, "Effect of HRT on Acedogenic Digestion of Primary Sludge," vol. 120, no. 3, pp. 645-660, 1994.

[8] A. Bouzas, C. Gabaldon, P. Marzal, J. M. Penya-Roja, and A. Seco, "Fermentation of municipal primary sludge: Effect of SRT and solids concentration on volatile fatty acid production," Environ. Technol., vol. 23, no. 8, pp. 863-875, 2002.

[9] E. Metcalf and H. Eddy, "Wastewater engineering: treatment and resource recovery," Tata McGraw-Hill Publishing Company Limited, 4th edition. New Delhi, India. p. 1819, 2014.

[10] N. Mahmoud, G. Zeeman, H. Gijzen, and G. Lettinga, "Anaerobic stabilisation and 
conversion of biopolymers in primary sludge - Effect of temperature and sludge retention time," Water Res., vol. 38, no. 4, pp. 983-991, 2004.

[11] E. A. Salminen and J. A. Rintala, "Semi-continuous anaerobic digestion of solid poultry slaughterhouse waste: Effect of hydraulic retention time and loading," Water Res., vol. 36, no. 13, pp. 3175-3182, 2002.

[12] K. M. Kangle, S. V Kore, V. S. Kore, and G. S. Kulkarni, "Recent Trends in Anaerobic Codigestion: A Review," Univers. J. Environ. Res. Technol., vol. 2, no. 4, pp. 210-219, 2012.

[13] S. Venkata Mohan, V. Lalit Babu, and P. N. Sarma, "Effect of various pretreatment methods on anaerobic mixed microflora to enhance biohydrogen production utilizing dairy wastewater as substrate," Bioresour. Technol., vol. 99, no. 1, pp. 5967, 2008.

[14] K. Nath, A. Kumar, and D. Das, "Hydrogen production by Rhodobacter sphaeroides strain O.U.001 using spent media of Enterobacter cloacae strain DM11," Appl. Microbiol. Biotechnol., vol. 68, no. 4, pp. 533-541, 2005.

[15] S. Zafar, "Anaerobic Digestion," Mech. Eng., no. February, pp. 1-7, 2018.

[16] T. H. E. Effects et al., "to the S qu i re d standard," 1986.

[17] R. P. T. Luu, P. Richard, M. Sergent, and N. Millot, "The effects of ph, temperature and agitation speed on sludge anaerobic hydrolysis-acidification," Environmental Technology Letters, vol. 9, no. 8. pp. 741-752, 1988.

[18] A. S. Ucisik and M. Henze, "Biological hydrolysis and acidification of sludge under anaerobic conditions: The effect of sludge type and origin on the production and composition of volatile fatty acids," Water Res., vol. 42, no. 14, pp. 3729-3738, 2008.

[19] M. Henze, "Capabilities of biological nitrogen removal processes from wastewater," Water Sci. Technol., vol. 23, pp. 669-679, 1991.

[20] Y. Miron, G. Zeeman, J. B. Van Lier, and G. Lettinga, "The role of sludge retention 
time in the hydrolysis and acidification of lipids, carbohydrates and proteins during digestion of primary sludge in CSTR systems," Water Res., vol. 34, no. 5, pp. 17051713, 2000.

[21] B. Rabinowitz and W. K. Oldham, "Excess biological phosphorus removal in the activated sludge process using primary sludge fermentation," Can. J. Civ. Eng., vol. 13, no. 3, pp. 345-351, 1986.

[22] Q. Wang, X. Zhou, L. Peng, D. Wang, G. J. Xie, and Z. Yuan, "Enhancing post aerobic digestion of full-scale anaerobically digested sludge using free nitrous acid pretreatment," Chemosphere, vol. 150, no. 5, pp. 152-158, 2016.

[23] H. Yu, Z. Wang, Q. Wang, Z. Wu, and J. Ma, "Disintegration and acidification of MBR sludge under alkaline conditions," Chem. Eng. J., vol. 231, pp. 206-213, 2013.

[24] J. Sánchez Rubal, J. A. Cortacans Torre, and I. Del Castillo González, "Influence of temperature, agitation, sludge concentration and solids retention time on primary sludge fermentation," Int. J. Chem. Eng., vol. 2012, 2012.

[25] P. Elefsiniotis and W. K. Oldham, "Influence of Ph on the Acid-Phase AnaerobicDigestion of Primary Sludge," J. Chem. Technol. Biotechnol., vol. 60, no. 1, pp. 8996, 1994.

[26] K. Y. Show, D. J. Lee, and J. S. Chang, "Bioreactor and process design for biohydrogen production," Bioresour. Technol., vol. 102, no. 18, pp. 8524-8533, 2011.

[27] A. Banerjee, P. Elefsiniotis, and D. Tuhtar, "The effect of addition of potatoprocessing wastewater on the acidogenesis of primary sludge under varied hydraulic retention time and temperature," J. Biotechnol., vol. 72, no. 3, pp. 203212, 1999.

[28] H. G. Yu and H. H. Fang, "Acidogenesis of dairy wastewater at various pH levels.," Water Sci. Technol., vol. 45, no. 10, pp. 201-206, 2002.

[29] E. U. Cokgor, S. Oktay, D. O. Tas, G. E. Zengin, and D. Orhon, "Influence of pH 
and temperature on soluble substrate generation with primary sludge fermentation," Bioresour. Technol., vol. 100, no. 1, pp. 380-386, 2009.

[30] E. U. Cokgor, G. E. Zengin, D. O. Tas, S. Oktay, C. Randall, and D. Orhon, "Respirometric assessment of primary sludge fermentation products," J. Environ. Eng., vol. 132, no. 1, pp. 68-74, 2006.

[31] by A. K. BANERJEE, The Effect Of Hydraulic Retention Time (HRT) and Temperature on the acid phase anaerobic digestion primary sludge and industrial wastewater. .

[32] P. Zhang, Y. Chen, and Q. Zhou, "Waste activated sludge hydrolysis and shortchain fatty acids accumulation under mesophilic and thermophilic conditions: Effect of pH," Water Res., vol. 43, no. 15, pp. 3735-3742, 2009.

[33] R. Moser-Engeler, K. M. Udert, D. Wild, and H. Siegrist, "Products from primary sludge fermentation and their suitability for nutrient removal," in Water Science and Technology, 1998, vol. 38, no. 1 pt 1, pp. 265-273.

[34] M. Gottardo, C. Cavinato, D. Bolzonella, and P. Pavan, "Dark fermentation optimization by anaerobic digested sludge recirculation: Effects on hydrogen production," Chem. Eng. Trans., vol. 32, pp. 997-1002, 2013.

[35] Y. H. Ahn and R. E. Speece, "Elutriated acid fermentation of municipal primary sludge," Water Res., vol. 40, no. 11, pp. 2210-2220, 2006.

[36] K. Nath and D. Das, "Improvement of fermentative hydrogen production: Various approaches," Appl. Microbiol. Biotechnol., vol. 65, no. 5, pp. 520-529, 2004.

[37] P. Zhang, Y. Chen, T. Y. Huang, and Q. Zhou, "Waste activated sludge hydrolysis and short-chain fatty acids accumulation in the presence of SDBS in semicontinuous flow reactors: Effect of solids retention time and temperature," Chem. Eng. J., vol. 148, no. 2-3, pp. 348-353, 2009.

[38] C. Mengmeng, C. Hong, Z. Qingliang, S. N. Shirley, and R. Jie, "Optimal production of polyhydroxyalkanoates (PHA) in activated sludge fed by volatile fatty acids (VFAs) generated from alkaline excess sludge fermentation," Bioresour. Technol., 
vol. 100, no. 3, pp. 1399-1405, 2009.

[39] D. Infantes, A. González Del Campo, J. Villaseñor, and F. J. Fernández, "Influence of $\mathrm{pH}$, temperature and volatile fatty acids on hydrogen production by acidogenic fermentation," Int. J. Hydrogen Energy, vol. 36, no. 24, pp. 15595-15601, 2011.

[40] H. Atherton, "Primary Sludge fermentation using a pilot-scale mainstream fermenter to enhance biological phosphorus removal.," no. July, 1995.

[41] E. Katsou, N. Frison, S. Malamis, and F. Fatone, "Controlled Sewage Sludge Alkaline Fermentation to Produce Vola- tile Fatty Acids to be Used for Biological Nutrients Removal in WWTPs," vol. I, no. 1, pp. 1-11, 2014.

[42] Q. L. Wu et al., "Enhancement of volatile fatty acid production by co-fermentation of food waste and excess sludge without $\mathrm{pH}$ control: The mechanism and microbial community analyses," Bioresour. Technol., vol. 216, 2016.

[43] X. Li, Y. Peng, Y. Zhao, L. Zhang, and B. Han, "Volatile Fatty Acid Accumulation by Alkaline Control Strategy in Anaerobic Fermentation of Primary Sludge," Environ. Eng. Sci., vol. 34, no. 10, pp. 1-8, 2017.

[44] H. Wu, J. Gao, D. Yang, Q. Zhou, and W. Liu, "Alkaline fermentation of primary sludge for short-chain fatty acids accumulation and mechanism," Chem. Eng. J., vol. 160, no. 1, pp. 1-7, 2010.

[45] H. Wu, D. Yang, Q. Zhou, and Z. Song, "The effect of pH on anaerobic fermentation of primary sludge at room temperature," J. Hazard. Mater., vol. 172, no. 1, pp. 196201, 2009.

[46] C. P. L. Grady, G. T. Daigger, and H. C. Lim, "Biological wastewater treatment," Hazard. Waste, vol. October, no. 19, p. 1076, 1999.

[47] R. Canziani, A. Pollice, and M. Ragazzi, "Feasibility of using primary-sludge mesophilic hydrolysis for biological removal of nitrogen and phosphorus from wastewater," Bioresour. Technol., vol. 54, no. 3, pp. 255-260, 1995.

[48] City of Toronto, "Ashbridges Bay Wastewater Treatment Plant 2008 Annual 
Report," pp. 1-66, 2009.

[49] HACH, "DR2900 Procedure Manual," no. May, 2003.

[50] S. J. Lim, B. J. Kim, C. M. Jeong, J. dal rae Choi, Y. H. Ahn, and H. N. Chang, "Anaerobic organic acid production of food waste in once-a-day feeding and drawing-off bioreactor," Bioresour. Technol., vol. 99, no. 16, pp. 7866-7874, 2008.

[51] M. A. Khan et al., "Optimization of process parameters for production of volatile fatty acid, biohydrogen and methane from anaerobic digestion," Bioresour. Technol., vol. 219, pp. 738-748, 2016.

[52] G. J. Hatziconstantinou, P. Yannakopoulos, and A. Andreadakis, "Primary sludge hydrolysis for biological nutrient removal," in Water Science and Technology, 1996, vol. 34, no. 1-2-2 pt 1, pp. 417-423.

[53] K. Luo et al., "Combined effect of sodium dodecyl sulfate and enzyme on waste activated sludge hydrolysis and acidification," Bioresour. Technol., vol. 102, no. 14, pp. 7103-7110, 2011.

[54] C. Mao, Y. Feng, X. Wang, and G. Ren, "Review on research achievements of biogas from anaerobic digestion," Renewable and Sustainable Energy Reviews, vol. 45. pp. 540-555, 2015. 